Universidad de Lima

Facultad de Comunicación

Carrera de Comunicación

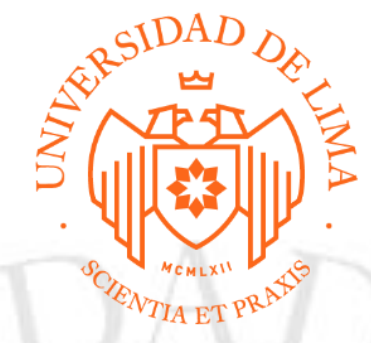

\title{
PROYECTO: CAMPAÑA DE LANZAMIENTO DEL CONDOMINIO VILLA DE ATLETAS
}

Trabajo de Suficiencia Profesional para optar el Título Profesional de Licenciado en Comunicación

\section{Cristian Patricio Espinoza Goycochea}

Código 20122708

Fiorella Alejandra Giribaldi Torrico

Código 20110519

$$
\text { Lima - Perú }
$$

23 de septiembre del 2019 


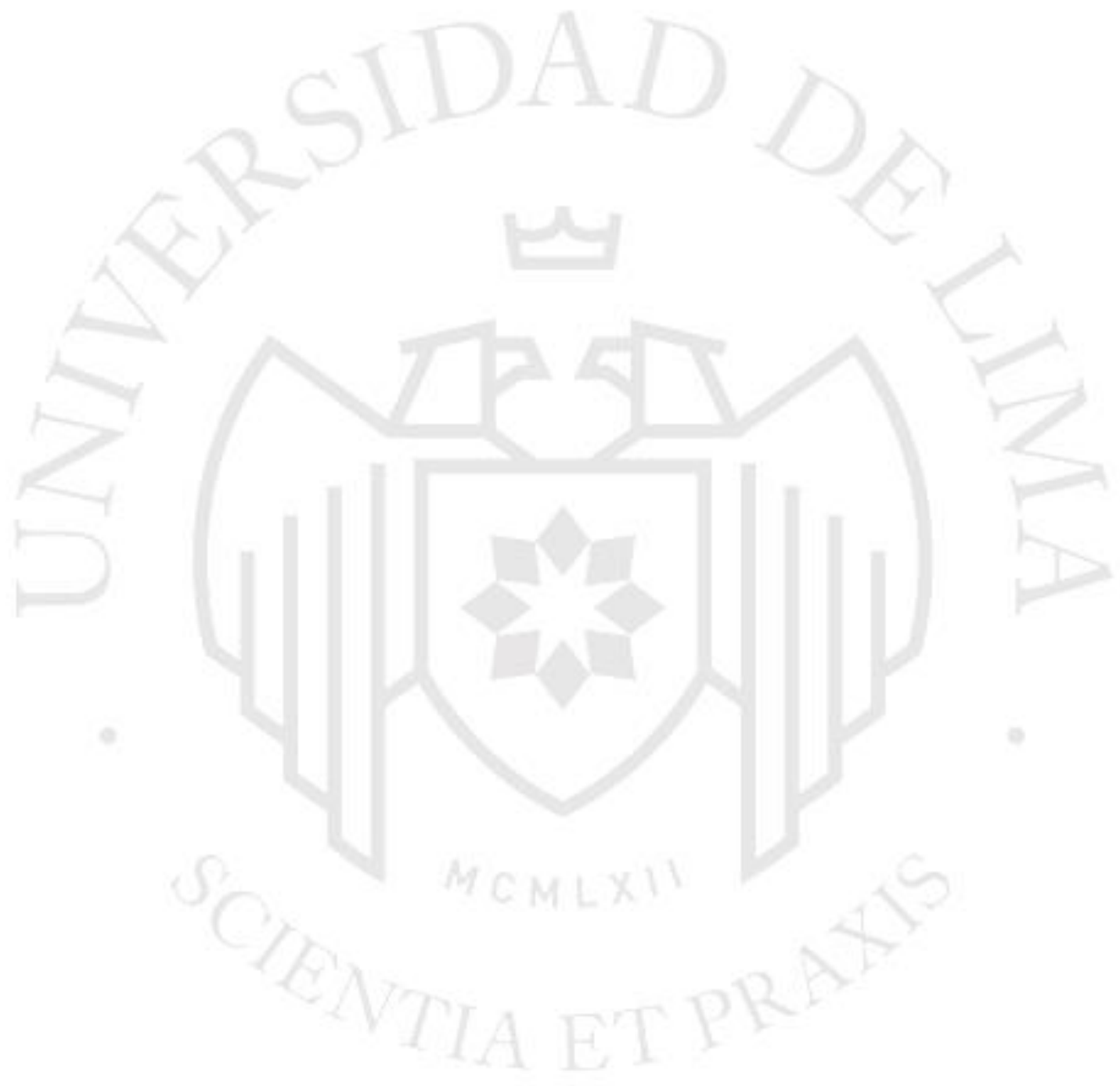


LANZAMIENTO DEL CONDOMINIO VILLA PANAMERICANA 


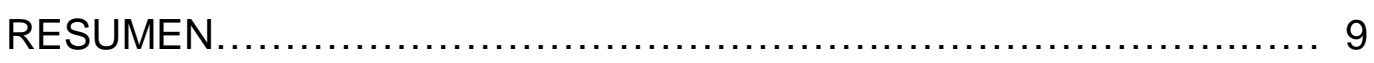

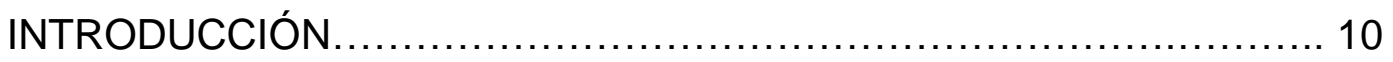

1. ANÁLISIS PESTAL_............................................................. 11

1.1 Análisis Político .................................................. 11

1.2 Análisis Económico...............................................11

1.3 Análisis Social........................................................ 14

1.4 Análisis Tecnológico ............................................... 14

1.5 Análisis Ambiental .................................................. 15

1.4 Análisis Legal.......................................................

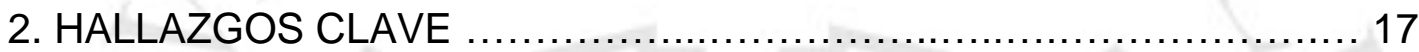

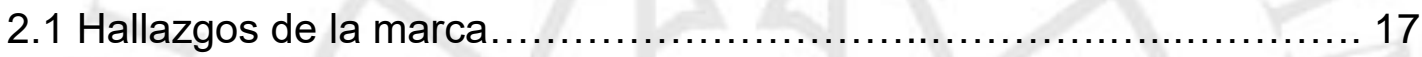

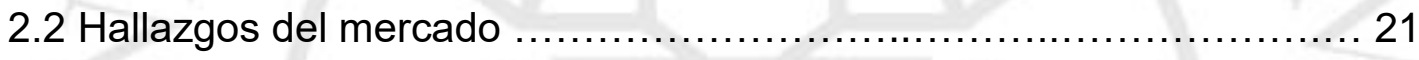

2.3 Hallazgos de la competencia........................................... 23

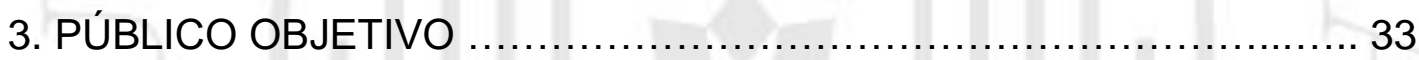

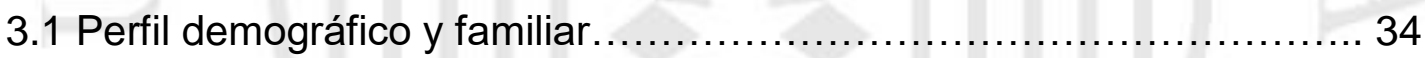

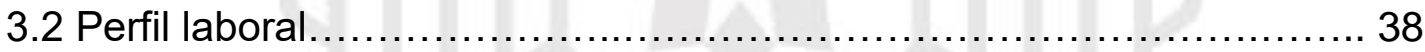

3.3 Perfil económico y financiero................................................. 38

3.4 Entretenimiento y consumo de medios.................................... 39

3.5 Comportamiento tecnológico .................................... 42

3.6 Comportamiento de consumo...................................... 44

3.7 Los Buyer Persona....................................................... 44

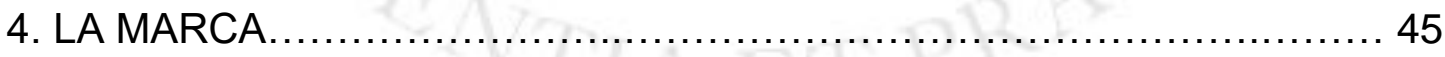

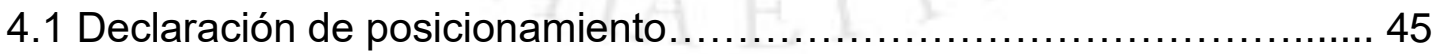

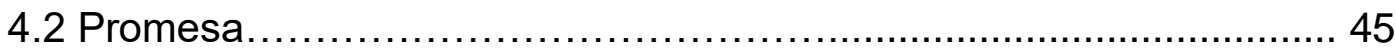

4.3 Ventaja diferencial.................................................... 45

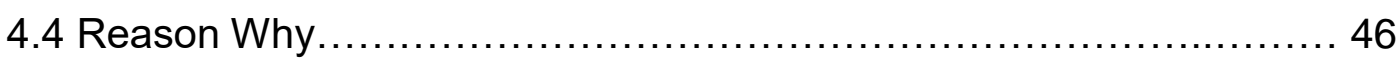

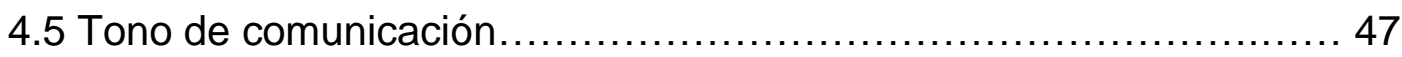

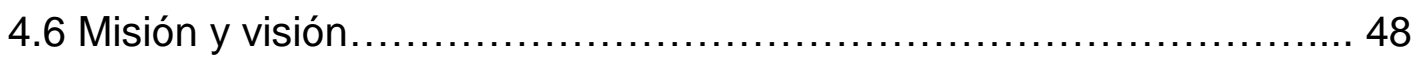

5. IDENTIDAD CORPORATIVA .......................................... 48

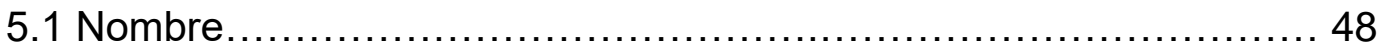




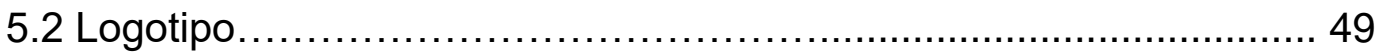

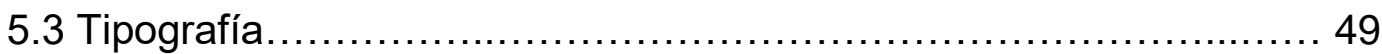

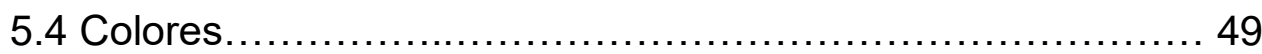

5.5 Simbolismos y formas........................................ 52

5.5 Imágenes que evoquen la marca................................ 52

5.6 Manual de marca............................................... 53

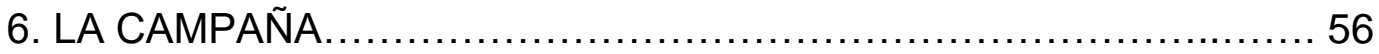

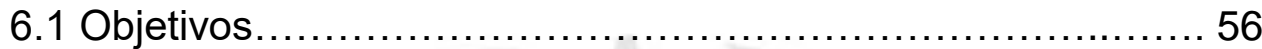

6.1.1 De marketing ........................................ 56

6.1.2 De comunicación........................................... 56

6.2 Estrategia creativa.............................................. 56

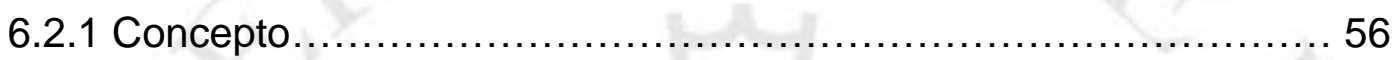

6.2.2 Idea racional......................................... 57

6.2 .3 Idea emocional......................................... 57

6.3 Estrategia de comunicación de la campaña.................... 57

6.4 Estrategia ATL.................................................. 59

6.4.1 Pre lanzamiento.......................................... 59

6.4.2 Lanzamiento ............................................. 60

6.5 Estrategia Digital...................................................... 64

6.5.1 Facebook ............................................... 65

6.5 .2 Instagram ............................................... 68

6.5 .3 Twitter................................................. 77

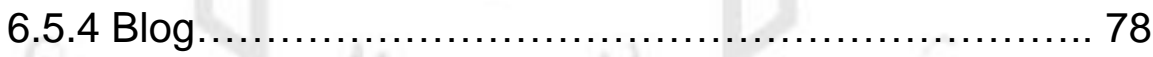

6.5.5 Contenido compartido ................................. 78

6.5.6 Marketing digital...................................... 79

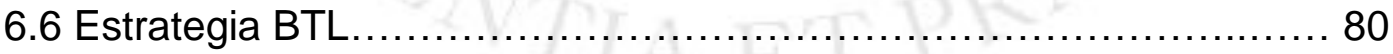

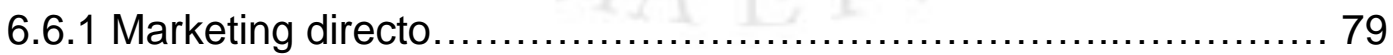

6.6.2 Festival Inmobiliario.................................... 80

6.7 Estrategia de medios......................................... 82

7. CONCLUSIONES ....................................................... 83

8. RECOMENDACIONES................................................. 84

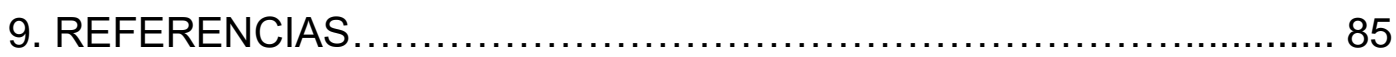


Dirección web de las piezas y producciones de comunicación parte del trabajo

Adjuntos:

https://drive.google.com/drive/folders/1iKAJecXVS7ZioWiTcgJ0sMd7MVMeu5d?usp=sharing 


\section{ÍNDICE DE TABLAS}

Tabla 1: Cuadro de elaboración propia tomando los datos de Ipsos 2018 ..... 37

Tabla 2: Cuadro de elaboración propia para buyers persona.....................45

Tabla 3: Cuadro de elaboración propia sobre los colores y su significado......52 


\section{ÍNDICE DE FIGURAS}

Figura 1: Lima Metropolitana. Población con empleo adecuado..............13

Figura 2: Lima Metropolitana. Ingreso promedio mensual......................14

Figura 3: Mapa Villa Panamericana ............................................ 19

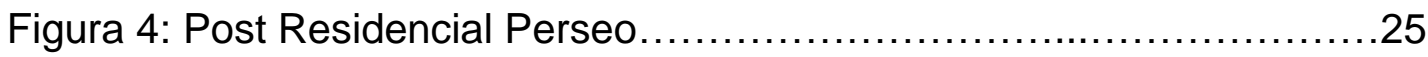

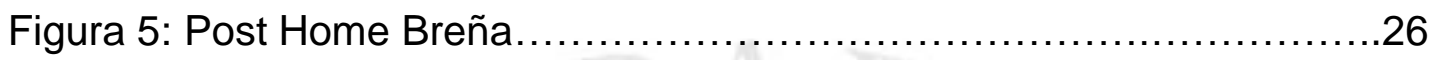

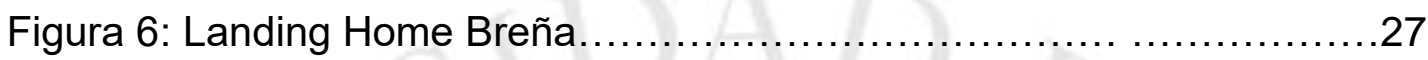

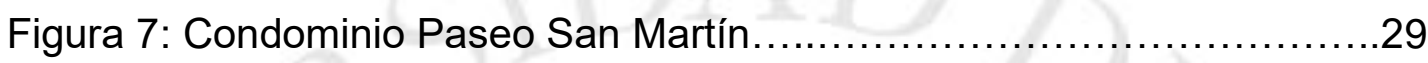

Figura 8: Screenshot video Ciudad Sol El Retablo...............................30

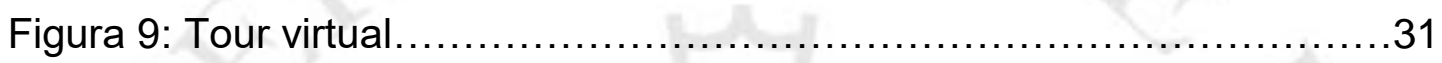

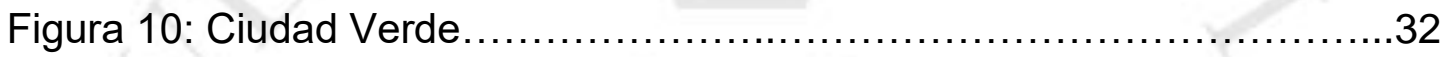

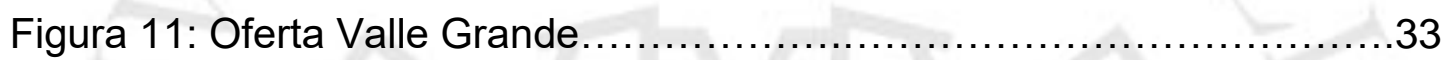

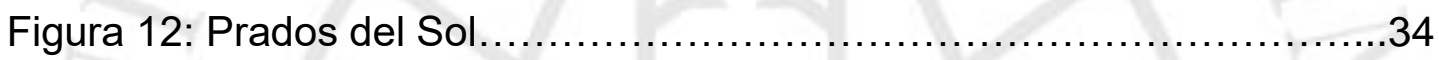

Figura 13. Perú 2019: Población por segmentos de edad según departamento.

Figura 14: Lima Metropolitana 2019: Hogares y población por sexo y

segmentos de edad según nivel socioeconómico. .36

Figura 15: Lima Metropolitana 2019. APEIM estructura socioeconómica de la población por sexo y segmento de edad según nivel socioeconómico..........36

Figura 16: Consumo de medios - Exposición 2018 .............................41

Figura 17: Consumo de medios tradicionales....................................41

Figura 18: Uso de smartphones en el Perú........................................42

Figura 19: Asistencia a formatos.............................................. 43

Figura 20: Asistencia a tiendas................................................... 44

Figura 21. Centros comerciales más recordados..............................44 


\section{RESUMEN EN ESPAÑOL}

Hemos logrado desarrollar una propuesta de marketing y comunicación para promover las ventas de departamentos en la Villa Panamericana, los cuales están dirigidos para las familias de adultos de entre 25 y 45 años del NSE $C$ y

$D$, los cuales buscan independencia y progreso en su calidad de vida.

Keywords: Campaña de lanzamiento, investigación del mercado Inmobiliario, estrategia comunicacional. 


\section{INTRODUCCIÓN}

El mercado limeño inmobiliario no cuenta con una oferta variada en lo que respecta a Lima Sur. Aunque por lo general se considera que los habitantes de esta zona de la ciudad son principalmente constructores de sus propias viviendas, una parte no descarta la idea de la compra. Además, con objeto de los Juegos Panamericanos y Parapanamericanos 2019, se creó la Villa Panamericana, para albergar a los asistentes a este evento deportivo internacional. De la misma manera, para promover la participación de atletas peruanos, los medallistas patrios han recibido un departamento cada uno. Como parte del legado, los departamentos restantes se encontrarán a la venta a partir del próximo año a precios muy competitivos, financiamiento y bonos que le otorgan una oportunidad única a muchas familias, debido a que facilitan la adquisición. La propuesta que se desarrolla aquí se basa en el uso de una comunicación efectiva a través de ATL, $\mathrm{OOH}$, Digital y BTL. Se desarrollarán 2 etapas: un pre-lanzamiento y un lanzamiento, con el objetivo de lograr optimizar nuestro alcance, transmitir las características del condominio y despertar el deseo la mayor cantidad de interés posible. 


\section{ANÁLISIS PESTAL}

\subsection{Análisis Político}

En cuanto al panorama político actual, en primer lugar, podemos señalar que venimos de un conflicto marcado entre el Poder Ejecutivo y el Poder Legislativo; es decir: entre el Congreso con una mayoría Fujimorista y el presidente y el Consejo de Ministros. Esta situación ha desencadenado un estancamiento en cuanto a proyectos de ley e iniciativas que podrían beneficiar el desarrollo del país.

Este conflicto entre Poderes, actualmente se encuentra en su punto más álgido a raíz de la propuesta del presidente de la República Martín Vizcarra que señaló el 29 de julio del 2019 el adelanto de las elecciones generales en el Perú para el 2020. (El Comercio, 2019)

Finalmente cabe señalar un caso emblemático en cuanto al destape de la corrupción del sistema público y privado: El Caso Odebrecht. Este destape ha revelado los "negociados" que se llevaban a cabo en las concesiones de obras públicas y ha puesto en jaque a funcionarios de cargos públicos en gran parte de Latinoamérica y en Perú. En este sinfín de denuncias, las más relevantes que podemos señalar son las que se dirigen hacia ex - presidentes, ex - ministros y ex -candidatos a la presidencia. (Fowks, 2019)

En síntesis, estamos sumergidos en una crisis política que puede traer consecuencias en el futuro progreso de nuestro país.

\subsection{Análisis Económico}

Desde el 2014 China se ha convertido en el principal socio comercial de nuestro país, es decir, el primer destino de nuestras exportaciones. Uno de principales impactos del enfrentamiento comercial entre EEUU y China ha provocado una reducción en los precios de los minerales que nuestro país exporta debido a que 
están en detrimento. Debido a este antagonismo, China ha reducido sus expectativas de crecimiento económico, lo que a su vez se materializa en una disminución en las expectativas de venta de minerales, fundamentales para nuestro desarrollo económico actual y futuro cercano. (RPP, 2019)

Adicionalmente a esto, según un estudio reciente realizado por Moody's Corporation, una agencia de calificación de riesgo que realiza la investigación financiera internacional y el análisis de las entidades comerciales y gubernamentales, el crecimiento del Producto Bruto Interno (PBI) peruano se desacelerará a aproximadamente $3.2 \%$ en el 2019 , 4\% menos que lo que se tenía proyectado en el 2018. (Gestión, 2019)

Según el INEI, el empleo adecuado en Lima Metropolitana tuvo un crecimiento de $2.4 \%$ entre mayo y julio del presente año. Los resultados de su informe arrojaron que la población con empleo adecuado creció en 73 mil personas durante ese trimestre, alcanzando de esta manera los 3 millones 153 mil 200, cifra que representa el $60.4 \%$ del total de la PEA que hay en Lima Metropolitana. (SEMANAeconómica.com, 2019)

\begin{tabular}{|c|c|c|c|c|}
\hline \multirow{2}{*}{$\begin{array}{l}\text { Sexo y grupos } \\
\text { de edad }\end{array}$} & \multirow{2}{*}{$\begin{array}{l}\text { Mayo-Junio- } \\
\text { Julio } 2018\end{array}$} & \multirow{2}{*}{$\begin{array}{l}\text { Mayo-Junio- } \\
\text { Julio } 2019\end{array}$} & \multicolumn{2}{|c|}{ Variación } \\
\hline & & & $\begin{array}{l}\text { Absoluta } \\
\text { (Miles) }\end{array}$ & $\begin{array}{l}\text { Porcentual } \\
\text { (\%) }\end{array}$ \\
\hline Total & 3080,2 & 3153,2 & 73,0 & 2,4 \\
\hline \multicolumn{5}{|l|}{ Sexo } \\
\hline Hombre & 2002,7 & 1997,9 & $-4,8$ & $-0,2$ \\
\hline Mujer & 1077,5 & 1155,3 & 77,8 & 7,2 \\
\hline \multicolumn{5}{|l|}{ Grupos de edad } \\
\hline De 14 a 24 años & 392,0 & 360,0 & $-32,0$ & $-8,2$ \\
\hline De 25 a 44 años & 1811,6 & 1862,2 & 50,6 & 2,8 \\
\hline De 45 y más años & 876,6 & 931,0 & 54,4 & 6,2 \\
\hline
\end{tabular}

Figura 1: Lima Metropolitana. Población con empleo adecuado

El ingreso promedio mensual de los trabajadores de Lima Metropolitana se posicionó en $S / 1,699,6$. Esto representa un $S / 29.1$ adicional con respecto a las cifras del año pasado. (SEMANAeconómica.com, 2019) 


\begin{tabular}{|c|c|c|c|c|}
\hline \multicolumn{5}{|c|}{$\begin{array}{l}\text { CUADRO No } 24 \\
\text { Lima Metropolitana: Ingreso promedio mensual } \\
\text { según sexo y grupos de edad } \\
\text { Trimestre móvil: Mayo-Junio-Julio } 2018 \text { y } 2019 \\
\text { (Soles, variación absoluta y porcentual) } \\
\end{array}$} \\
\hline \multirow[b]{2}{*}{ Sexo/ Grupos de edad } & \multirow{2}{*}{$\begin{array}{c}\text { Mayo-Junio- } \\
\text { Julio } 2018\end{array}$} & \multirow{2}{*}{$\begin{array}{l}\text { Mayo-Junio- } \\
\text { Julio } 2019\end{array}$} & \multicolumn{2}{|c|}{ Variación } \\
\hline & & & $\begin{array}{l}\text { Absoluta } \\
\text { (Soles) }\end{array}$ & $\begin{array}{c}\text { Porcentual } \\
(\%)\end{array}$ \\
\hline Total & 1670,5 & 1699,6 & 29,1 & 1,7 \\
\hline \multicolumn{5}{|l|}{ Sexo } \\
\hline Hombre & 1894,6 & 1955,7 & 61,1 & 3,2 \\
\hline Mujer & 1391,3 & 1393,2 & 1,9 & 0,1 \\
\hline \multicolumn{5}{|l|}{ Grupos de edad } \\
\hline De 14 a 24 años & 1014,9 & 1032,8 & 17,9 & 1,8 \\
\hline $\mathrm{De} 25$ a 44 años & 1741,6 & 1781,1 & 39,5 & 2,3 \\
\hline De 45 y más años & 1946,8 & 1903,0 & $-43,8$ & $-2,3$ \\
\hline
\end{tabular}

Fuente: Instituto Nacional de Estadistica e Informática - Encuesta Permanente de Empleo.

Figura 2: Lima Metropolitana. Ingreso promedio mensual.

Por otro lado, el sector construcción continuará beneficiándose de la sólida cartera de proyectos privados y públicos. Con respecto al sector Construcción este tuvo un crecimiento de 7.5\%. (SEMANAeconómica.com, 2019)

Juan Carlos Tassara, el presidente de la Asociación de Empresas Inmobiliarias del Perú (ASEI) informó que este año registraremos un crecimiento en la venta de viviendas de entre $10 \%$ y $15 \%$ en relación al año 2018. Señaló que la demanda de viviendas es tan grande que, aunque la economía no haya logrado los niveles de crecimiento esperados, ha seguido avanzando al igual que la venta. Es así como el $25 \%$ de las viviendas que se compran en el Perú son a través del Fondo Mivivienda. (El Comercio, 2019)

Según la inmobiliaria Paz Centenario, el mercado inmobiliario de Lima finalizaría el año con un aumento en sus precios y el valor por metro cuadrado $\left(\mathrm{m}^{2}\right)$ aumentaría entre $5 \%$ y $8 \%$ para finales de 2019 . De esta manera, se estima que 
hay 190.000 familias que pueden adquirir viviendas solo en Lima, esto sumado a una oferta constante de 20.000 inmuebles al mes. (El Comercio, 2019)

\subsection{Análisis Social}

Según un artículo reciente publicado por ESAN, el $86 \%$ de los consumidores espera que las marcas tomen una posición respecto a temas de relevancia social. Entre las tendencias de consumo por las que se inclinarán se encuentran el activismo y la tecnología. Es así como las organizaciones deberán potenciar estrategias capaces de desencadenar cambios productivos y que apuesten por la sostenibilidad. (ESAN, 2019)

El 54\% de hogares peruanos sigue la tendencia de buscar una alimentación saludable, por lo que cada vez más peruanos se preocupan por consumir frutas, verduras, beber agua y leer la información nutricional en las etiquetas de los empaques. (Suito, 2019)

Un estudio de CCR expuso que cinco de cada 10 limeños realizan alguna actividad deportiva, siendo el fútbol el más popular. De acuerdo con el informe, los hombres menores de 45 años son los más activos en el aspecto deportivo. Adicionalmente vale señalar que dos de cada cinco limeños que practican actividades deportivas prefieren los gimnasios. (Portal PQS, 2019)

\subsection{Análisis Tecnológico}

Comscore, empresa socia del IAB Perú, compartió en un reciente estudio que un peruano utiliza en promedio 409.2 minutos en redes sociales, casi 7 horas. Facebook con $44,5 \%$ de las publicaciones y después Twitter con un $31.5 \%$. En cuanto a interacciones, Facebook encabeza la figura con un $48,6 \%$, seguido de Instagram con un 28,9\%. (El Comercio, 2019) 
El alcance del social media es de 93.2\%, razón por la que Perú lidera el listado con más relevancia en la categoría de social media. (Gestión, 2019)

La mitad de los usuarios de telefonía móvil en el Perú se conecta a internet desde tu teléfono. Un $28 \%$ usa los datos móviles, mientras que el $18 \%$ usa wifi. IPSOS

En el primer trimestre de 2019, el 93,0\% de los hogares del país tienen al menos una tecnología de información y comunicación, sea celular o teléfono fijo o Internet o TV por cable. INEI

La realidad aumentada se perfila como una de las tendencias más atractivas para el 2020 y, junto a la realidad virtual, están cambiando la forma de percibir el mundo digital y conducirán a la futura experiencia inmersiva del usuario. La idea es producir experiencias que envuelvan al usuario. (Gestión, 2019)

\subsection{Análisis Ambiental}

Actualmente, a nivel Mundial la preocupación sobre el medio ambiente se ha visto alimentada a raíz de los múltiples incendios que durante semanas arrasaron con parte de la selva del Amazonas.

Por su lado, el Perú continúa mejorando su situación dentro de los Objetivos de Desarrollo Sostenible (ODS) de la ONU con miras al 2030. Esto significa que organizaciones privadas, públicas y líderes de todos los sectores empresariales optimizan sus esfuerzos por desarrollar mejoras en cuanto a sostenibilidad, medio ambiente, bienestar social, entre otros temas. (ESAN, 2018)

Hay una tendencia por parte de los consumidores y empresas hacia el reciclaje y la reducción de bolsas plásticas, sorbetes y demás utensilios plásticos 
d un solo uso no-biodegradables, sin embargo, Lima sigue siendo la octava ciudad más contaminada de Latinoamérica. Esto debido al exceso de autos que según World Air Quality provocaría al menos que 15 mil personas padezcan de enfermedades respiratorias y cardiovasculares debido a la contaminación (Gestión, 2019).

\subsection{Análisis Legal}

En primer lugar, vale la pena mencionar las iniciativas legislativas hacia la promoción de nuevas facilidades para la adquisición de inmuebles: opciones de financiamiento, bonos y demás beneficios ofrecidos por entidades públicas. Por un lado, tenemos el fondo Renta Joven, próximo a implementarse y en el que el Gobierno otorgará un bono mensual de S/495.6 a las parejas jóvenes de bajos recursos para que paguen parte de su alquiler. El ministro de Vivienda, Miguel Estrada indicó que iniciarán con un lanzamiento de 2,000 bonos en tres ciudades: Lima, Arequipa y Trujillo. (RPP, 2019)

Esta iniciativa busca que los integrantes del grupo familiar puedan ahorrar para la compra de una propiedad en el futuro. (Atúncar, 2019)

Por otro lado, existe el fondo Mivivienda en el que existen dos bonos que vale la pena mencionar: El Bono del Buen Pagador y El Bono Mivivienda Verde. El Bono del Buen Pagador es una ayuda económica directa que se otorga a las personas que adquieren un producto MiVivienda, través de las instituciones financieras intermediarias que cumplan con el pago puntual de sus cuotas. Para el caso de las viviendas que cuesten entre $S / 125,900$ y S/ 209,800, el BBP es de $S / 13,000$. Con respecto a Mi Vivienda Verde, en los últimos meses se han registrado facilidades que antes no existían para la adquisición de una casa propia, como la posibilidad de acceder a un crédito hipotecario Techo Propio del programa Mivivienda con una cuota inicial de hasta $5 \%$ del valor total de la vivienda. (Gestión, 2019)

"Por ejemplo, hay entidades bancarias que piden cuotas iniciales de hasta $5 \%$ para créditos de Techo Propio del Programa Mivivienda y de hasta $10 \%$ para 
el resto de las hipotecas", indica el Ministerio de Economía y Finanzas (MEF) en el Marco Macroeconómico Multianual 2020-2023. (Andina, 2019)

\section{HALLAZGOS CLAVES}

\subsection{Hallazgos de la Marca}

La Villa Panamericana fue construida por la constructora Besco-Besalco para alojar a las distintas delegaciones de los Juegos Panamericanos y para albergar a los 6.600 deportistas de 41 países que nos visitaron durante los Juegos Panamericanos y Parapanamericanos de Lima (Gestión, 2019). Según datos del Ministerio de Economía y Finanzas, se invirtieron S/ 405 millones en la construcción y operación de la Villa Panamericana (Bambarén, 2019)

La Villa está conformada por 1,096 departamentos de 70 y 75 metros cuadrados distribuidos en cuatro torres de 20 pisos y tres torres con 19 pisos. Hay ocho departamentos por piso, además de dos sótanos por torre. Algunas de estas viviendas serán otorgadas para los deportistas que ganaron medallas en la competencia deportiva, por lo que los edificios han sido diseñados bajo un estándar de accesibilidad universal y se destaca por ser uno de los primeros complejos habitacionales construidos con ingeniería y arquitectura inclusiva, lo que garantiza la accesibilidad de personas con discapacidad física y visual (Gestión, 2019). 


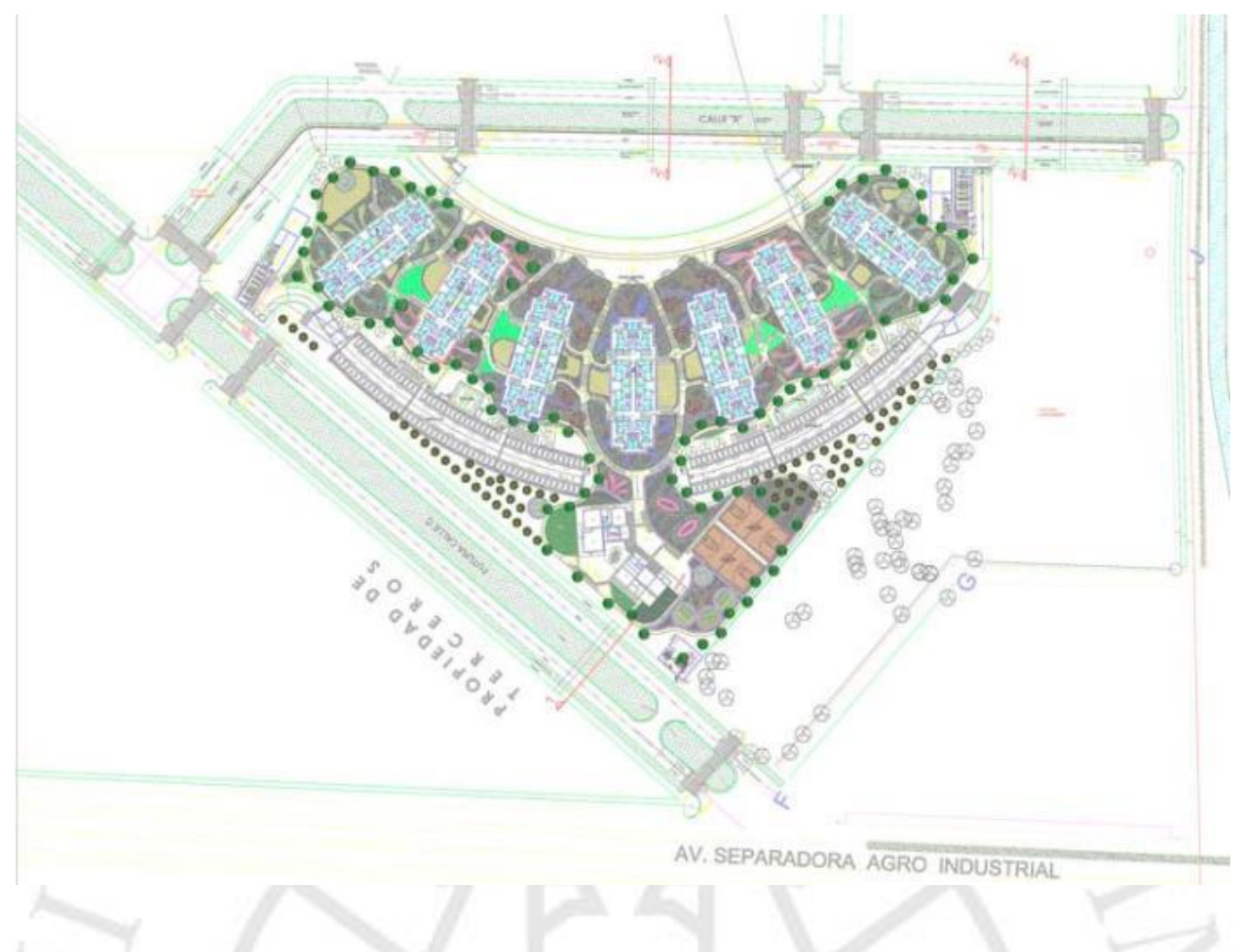

Figura 3: Mapa Villa Panamericana

Se planteó la distribución de los bloques de vivienda en un eje curvo central, y distribuyendo los edificios de forma radial, de tal forma que todos los departamentos tengan vistas a las áreas verdes centrales y brindándoles a su vez una buena iluminación interior (Construcciónyvivienda.com, 2019)

Los ingresos peatonales se plantearon por la Calle $\mathrm{B}$, conectándose con una vía secundaria auxiliar mediante la cual se accede a la villa. Esta vía también se comunica con una plaza central de integración que organiza la distribución radial de los bloques por una serie de caminos peatonales que conducen hacia los ingresos de cada conjunto de viviendas. Para el ingreso vehicular, se planteó una vía en la Calle B y una más en la Calle $C$ hacia los bloques de estacionamiento por medio de rampas vehiculares. En total se han edificado 367 estacionamientos distribuidos en dos bloques. (Construcciónyvivienda.com, 2019)

El espacio de integración social, llamado "la casa club", es conformado por tres salas multiusos, una sala de juego para jóvenes, una sala de juego para niños y 
un gimnasio. Como complemento, las zonas de esparcimiento incluyen dos losas deportivas multiusos y una ciclovía de $1 \mathrm{~km}$. "La casa club incluye además un sótano que cuenta con la Cisterna $N^{\circ} 1$ y $N^{\circ} 2$ de Agua Contra Incendio, Cuarto de Bombas, Cisterna No 2A de Agua Consumo Edificio 3, 4 y 5, Cisterna $N^{\circ} 2 B$ de Agua Consumo Edificio 6 y 7 , además de la escalera hacia el primer piso. El área construida para cisterna comprende 408.42 m2." (Construcciónyvivienda.com, 2019)

Con el objetivo de brindar un valor agregado al proyecto, la villa de atletas contempla un sistema de riego de áreas verdes. Consiste en separar los desagües en aguas negras y aguas grises, a fin de conducir estas últimas hacia dos humedales artificiales que servirán para el riego de las áreas verdes del proyecto. Estas características le brindan al proyecto la certificación de Bono Verde.

"Las aguas grises son dirigidas a una planta de tratamiento (humedal) donde se purificará lo suficiente para convertirla en agua de riego. Con ello, las áreas verdes que circundan las siete torres no van a requerir usar el agua de la red pública, sino que van a ser regadas con la misma agua que se usa en los baños de los departamentos", detalla Rafael Correa, el director del proyecto de la constructora Besco-Besalco.

Con el objetivo de optimizar el uso de agua, se optó por combinar áreas verdes con otros acabados como piedra tipo canto rodado o confitillo, como por plantas y árboles que no consumen mucha agua. (Construcciónyvivienda.com, 2019)

Más del $30 \%$ de los departamentos de la Villa Panamericana cumplen con todas las condiciones de movilidad para ser ocupados por personas con discapacidad

- Las puertas de acceso al departamento y estancia principal son de $90 \mathrm{~cm}$ de ancho para que una silla de ruedas pueda pasar sin dificultades.

- Se colocaron barras de apoyo en las paredes y están situadas a una distancia adecuada, para que puedan usarse para mantener el equilibrio. 
- Los pasillos y puntos de giro, así como los pasillos en línea recta, tienen el espacio suficiente para la libre movilidad de una persona con silla de ruedas y la señalización de seguridad está en lenguaje Braille.

- En el baño y en la ducha se cuenta con barras de apoyo y sujeción para facilitar la accesibilidad, acorde al Reglamento Nacional de Edificaciones (RNE) A130.

- La ducha tiene un banco en su interior.

- Los pasadizos de cada piso de todos los edificios son más amplios y la señalización de seguridad está en lenguaje Braille. (Andina, 2019)

En este contexto es crucial señalar que según cifras de la Asociación de Desarrolladores Inmobiliarios del Perú (ADI), el costo del metro cuadrado en Villa El Salvador asciende a S/ 2,700 en promedio (Bambarén, 2019). Esto quiere decir que un departamento de 75 metros cuadrados en el distrito bordearía los S/ 202 mil soles, casi la mitad del precio de costo de los departamentos de la Villa Panamericana.

Otro aspecto a considerar son los precedentes en experiencias similares: otros países organizadores de los juegos también construyeron villas para albergar a los deportistas. Tomaremos como ejemplo los casos de Guadalajara 2011, Londres 2012, Toronto 2015 y Río 2016 que también cuentan con infraestructura inmobiliaria de legado.

En el caso de la Villa Panamericana de Guadalajara de 2011 por ejemplo, podemos señalar que fue edificada al lado del Bosque La Primavera, área natural protegida y donde la construcción está prohibida. En la actualidad la Villa permanece desierta ante las innumerables investigaciones en corrupción que también involucran a la edificación, por lo que su futuro aún es incierto a la fecha (Bambarén, 2019).

En segundo lugar, podemos mencionar la Villa Olímpica Ilha Pura (Isla Pura), legado de los Juegos Olímpicos de Río 2016. El problema principal es que fue construida por un consorcio integrado por Carvalho Hosken y Odebrecht. Desde el 2016 solo se han logrado vender el 15\% de departamentos ante las 
acusaciones del caso Lava Jato, haciendo que sea imposible a la fecha relanzar el proyecto para recuperar la inversión (Bambarén, 2019)

Por otro lado, también existen casos más favorables como el de la Villa Olímpica de los Juegos de Londres 2012. Finalizadas las actividades deportivas, el 50\% de las viviendas fue otorgado a una empresa privada para el alquiler de viviendas de lujo. Un $25 \%$ fue destinado a un fondo de vivienda para la venta a costo intermedio y otro $25 \%$ destinado para la venta a un precio social.

Otro caso similar es el de la Villa Panamericana de Toronto 2015, construida al lado de una universidad y donde se tuvo la idea de que una de las seis torres fuera destinada para la residencia de los alumnos por este motivo. Actualmente, las viviendas se encuentran en pleno uso. (Bambarén, 2019)

\subsection{Hallazgos del Mercado}

De acuerdo con un reporte de preferencias del consumidor de la última edición del ExpoUrbania, más del $50 \%$ de los limeños está interesado en adquirir un inmueble en Lima moderna integrada por los distritos de Jesús María, Magdalena, San Miguel, Pueblo libre y Lince.

Se determinó que el $23 \%$ se inclina por comprar un inmueble en la zona top de Lima integrada por los distritos de San Isidro, San Borja, Miraflores y Surco. De este porcentaje, la mayor preferencia recae en la llamada "Generación silenciosa" (45\%), seguidos por los baby boomers (31\%), y los centennials (28\%). (Revista Gan@Más, 2019)

De acuerdo con un informe reciente sobre el "Perfil del consumidor" realizado por Urbania.pe: "[...] en Lima Moderna se concentra el $62.6 \%$ de los inmuebles comprados en los últimos 2 años. En segundo lugar, se ubica Lima Top con 13.2\%; Lima Centro con 10.7\%; Lima Sur con 7.5\%; Lima Este con 3.8\%, fuera de Lima Metropolitana con $1.7 \%$; Callao con $0.3 \%$; y Lima Norte con $0.2 \%$ " (Gestión, 2019) 
En el mismo estudio se señala que el $63.8 \%$ de los millennials en Perú busca un inmueble por el canal online, seguidos de la generación $X$ con 23.7\%; generación $Z$ con $7.7 \%$, los baby boomers con $4.7 \%$ y la generación silenciosa con $0.1 \%$; y que han adquirido inmuebles de 3 habitaciones un 62\% baby boomers, un 57\% de generación $X$ y un 53\% de millennials. Además, el 59.3\% de ellos tiene la disposición de comprar una vivienda a corto plazo, continúa la generación $\mathrm{X}$ (28.8\%), los baby boomers (6.9\%) y la generación Z (4.7\%) (Gestión, 2019).

En cuanto a los distritos con mayor demanda de compra en primer lugar se ubica Jesús María con 14.4\%; en segundo lugar, San Miguel con $13.2 \%$, luego Surquillo con $11.5 \%$, seguido de Magdalena del Mar con $10.7 \%$ y finalmente Pueblo Libre con 7.5\% (Gestión, 2019).

Adicionalmente, un dato clave es la previsión de un nuevo boom inmobiliario que se podría registrar en Lima Sur a partir del próximo año. Así lo señala el jefe de sector inmobiliario de Properati, Carlos Vourakis: "Ello se debe a que carecen de planes inmobiliarios porque se opta por la autoconstrucción o la ampliación de la casa familiar". Cabe mencionar también que los distritos aledaños de San Juan de Miraflores, Villa María del Triunfo y Lurín tampoco cuentan con programas de vivienda social. (El Peruano, 2019)

Por otro lado, de acuerdo a la gerente general de la Asociación de Desarrolladores Inmobiliarios (ADI Perú), Carola Pacheco, en los últimos años los millennials están haciéndose notar como atractivos potenciales compradores dentro del rubro inmobiliario. Al tratarse de profesionales que buscan espacios más pequeños ahora es común encontrar ofertas de viviendas que miden 50 metros cuadrado en promedio (El Comercio, 2019).

Marco Del Río, presidente ejecutivo de ADI PERÚ, señaló que para julio del 2019 se vendieron 5,945 unidades inmobiliarias de 51 a 80 metros cuadrados; menores o iguales a 50 metros cuadrados, 1,427 unidades inmobiliarias; de 81 a 100 metros cuadrados, 1,212; y a partir de los 100 metros cuadrados, 1,981. Según la gerente general de ADI PERÚ, Carola Pacheco a julio de este año se 
alcanzaron las 10,565 unidades inmobiliarias vendidas en Lima; en promedio, 1,509 por mes. De acuerdo a estas cifras, se prevé que se mantendrá la proyección de venta de viviendas para este año establecida en el objetivo de ventas de 16,000 unidades, un $8 \%$ más comparado al 2018. (Confiep, 2019)

\subsection{Hallazgos de la competencia (Benchmark)}

La definición de la competencia que hemos realizado para su posterior análisis se está basado, principalmente, en el precio de los inmuebles. Esto debido a que consideramos que el precio es la mayor restricción para adquirir un departamento.

A pesar de lo anterior, tomaremos en cuenta algunas prácticas y estrategias de empresas en el rubro inmobiliario, aunque estas se dirigen a un público objetivo distinto al de la Villa Panamericana, uno con un poder adquisitivo mayor.

Cabe señalar que los parámetros en podremos énfasis son ubicación geográfica, el precio, el área del departamento, los bonos y métodos de financiamiento y su comunicación en los diferentes medios.

\section{- Residencial PERSEO}

Es el proyecto inmobiliario más cercano a la Villa Deportiva, se encuentra en Chorrillos y cuenta con prestaciones similares, aunque el precio es más elevado. Su estrategia se basa en aparecer en sitios, portales y ferias digitales. Resaltan sus áreas comunes como sus principales atributos: gimnasio, zona infantil, zona de parrillas y jardines. A pesar de ello no tiene ningún atributo diferencial que podamos resaltar.

Los departamentos de 2 dormitorios tienen un área de 55 metros cuadrados y cuestan $\mathrm{S} / 217,000$.

La comunicación de la inmobiliaria responsable por el proyecto en redes sociales no pasa por algo más que por una publicación periódica de un álbum de fotos para comunicar su desarrollo, vemos que se encuentran 
más interesados en comunicar otros proyectos que son más costoso y se encuentra en distritos con un metro cuadrado más elevado como Miraflores y Barranco.

\section{aran Arango Inmobiliaria \\ 12 de marzo de 2015 -}

Residencial Perseo - \#Chorrillos \#Lima \#Peru - Envianos un mensaje directo con tu correo electrónico y te mandamos todo el material informativo

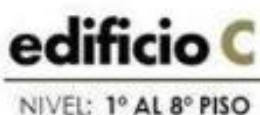

Tipo $\times 02, \times 05$

AREA TECHADA : $67.42 \mathrm{M2}$

(AREAS APROXMMADAS)

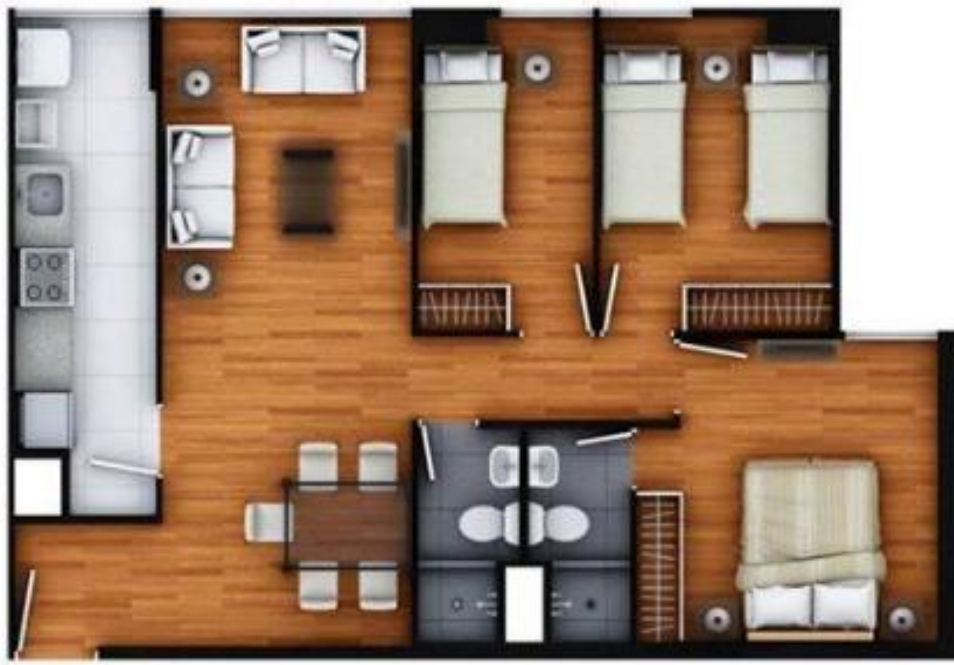

arango

Figura 4: Post Residencial Perseo

El caso de la Residencial PERSEO hay que resaltar que es el único proyecto de su tipo en Lima sur, no hemos logrado encontrar proyectos residenciales con un precio cercano (aunque este sea superior) al que ofrece la Villa Panamericana.

- Home Breña 
Es un proyecto inmobiliario que enfoca en ofrecer departamentos de una manera segmentada, el precio del más económico $(S / 200,000)$ dista del más costoso $(307,977)$. Esta torre con 21 pisos, los cuales comprenden 60 departamentos y áreas sociales. Cuenta con una ubicación la cual puede considerarse céntrica, puesto que la Av. Arica tiene supermercados, colegios, comercios y una la futura estación del metro Línea 2.

El atributo clave que resaltan en la comunicación del producto es el acceso al Bono Verde de Mivivienda del cual profundizamos en el análisis legal. Este bono permite una mayor accesibilidad y menor consumo en los servicios básico de agua y luz. Esa coherencia también se traslada a las redes sociales que son más activas y comunican de manera constante los atributos de la marca.

\section{Constructora Betania}

20 de agosto a las 17:00 - 8

¿Conoces los beneficios del Bono Verde? 0 .

Los departamentos dentro del programa te permiten ahorrar en agua y luz. pero además te permite financiar la compra de tu depa con una menor tasa de interés, obteniendo una cuota mensual más baja que un crédito convencional.

Recuerda que nuestros proyectos Alameda y Home, cuentan con la certificación del Bono Verde. Conócelos aqui: https://bit.ly/2LofNwt

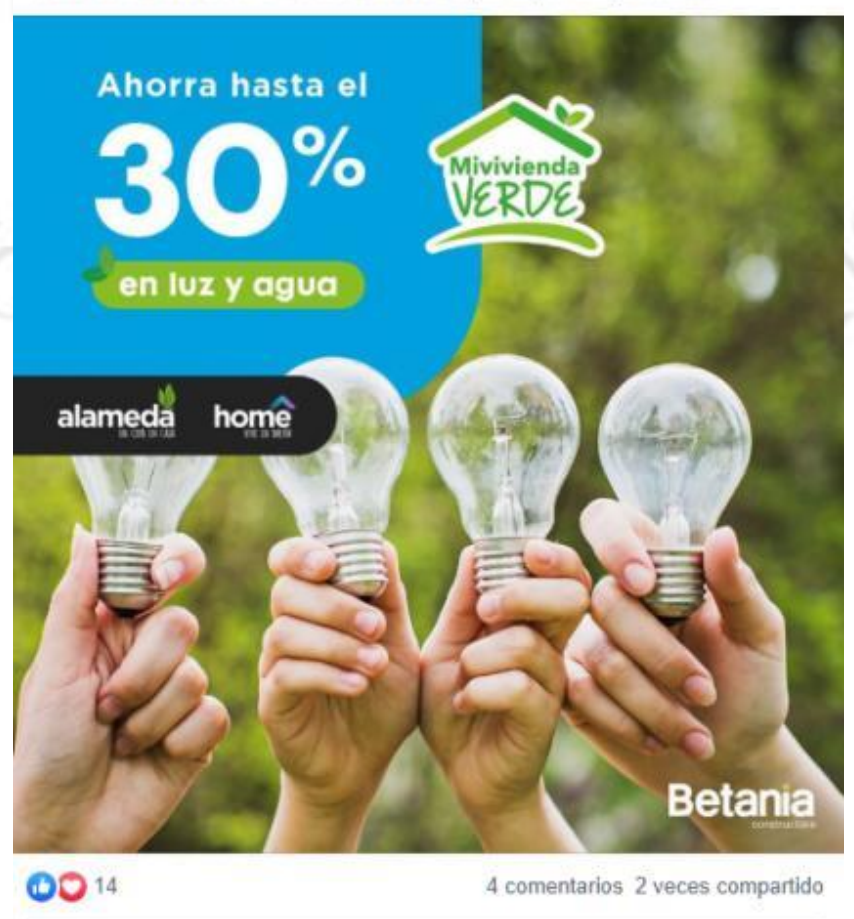

Figura 5: Post Home Breña 
Podemos resaltar el uso de una estrategia más completa, debido al uso de una landing page para no depender totalmente de portales como Urbania o Nexo Inmobiliario. Además, la obtención de leads y base de datos notable para el largo plazo de su empresa y para una comunicación más directa con el potencial comprador.

iMúdate a Breña! Av. Arica 1120, Breña

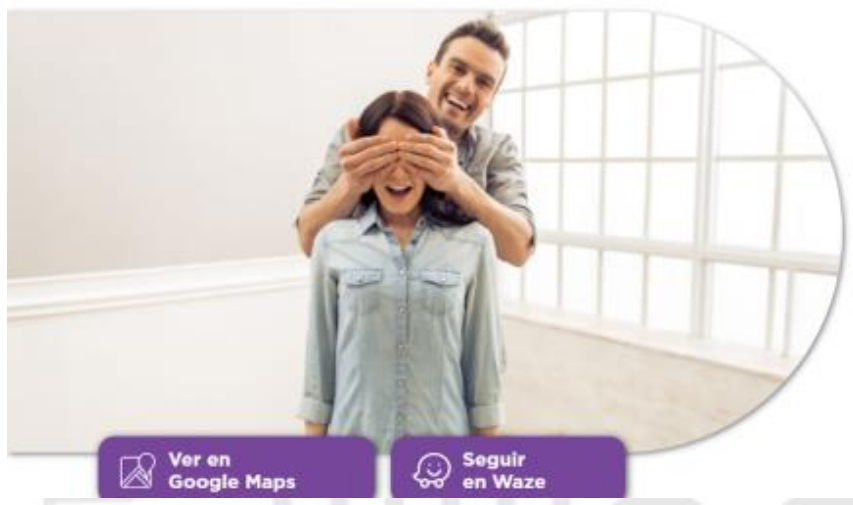

Déjanos tus datos y un asesor se comunicará contigo

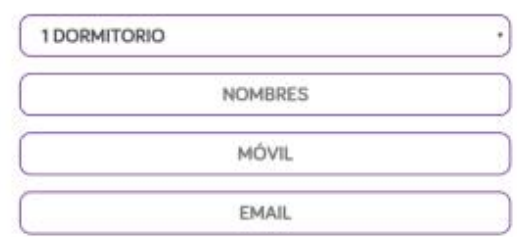

$\square$ Acepto términos y condiciones

Figura 6: Landing Home Breña

- Paseo San Martín

Es un condominio compuesto por 5 torres de 456 departamentos. Los departamentos comprendidos como competencia por su precio tienen un área de 51.04 metros cuadrado con un precio de $\mathrm{S} /$ 171,000, 53.89 metros cuadrados con un precio de S/ 188,000 y 66.82 metros cuadrados a S/ 209,000 . El proyecto tendrá 3 pisos de estacionamientos, 1 club house y aproximadamente $1800 \mathrm{~m} 2$ de áreas verdes. Las cuales lo hacen calificar para el Bono Verde y el Fondo Mivivienda, es decir, facilidades de financiamiento y bajos costos en los servicios. 
Este competidor, comienza a ser lejano, geográficamente hablando, de la Villa Panamericana, pues se encuentra en la Av. 10 de junio №1020, San Martín de Porres (Lima Norte).

En cuanto a su manejo en medios digitales podemos señalar que su página web no está optimizada para ser un landing page eficiente y sus redes sociales, a pesar de tener un manejo estructurado y positivo, no crean un ecosistema con la web de la misma. También se manifiesta en los diversos portales digitales se llevan bajo el nombre de la constructora Inarco, la cual se apoya bajo su pilar de confianza en base a su trayectoria. Como positivo señalamos un lado más lúdico y activo en social media que el resto de la competencia con publicaciones de imágenes 3D y $360^{\circ}$ en Facebook. 
d. Inarco Perú

Imanco 28 de agosto a las 16:41.

Tu familia se merece siempre lo mejor! Múdate a Paseo San Martín y disfruten juntos de nuestras áreas comunes $100 \%$ equipadas!

Para mayor información escríbenos por WhatsApp 엘 +51964388814 o en http://bit.ly/lnarco_SanMartin
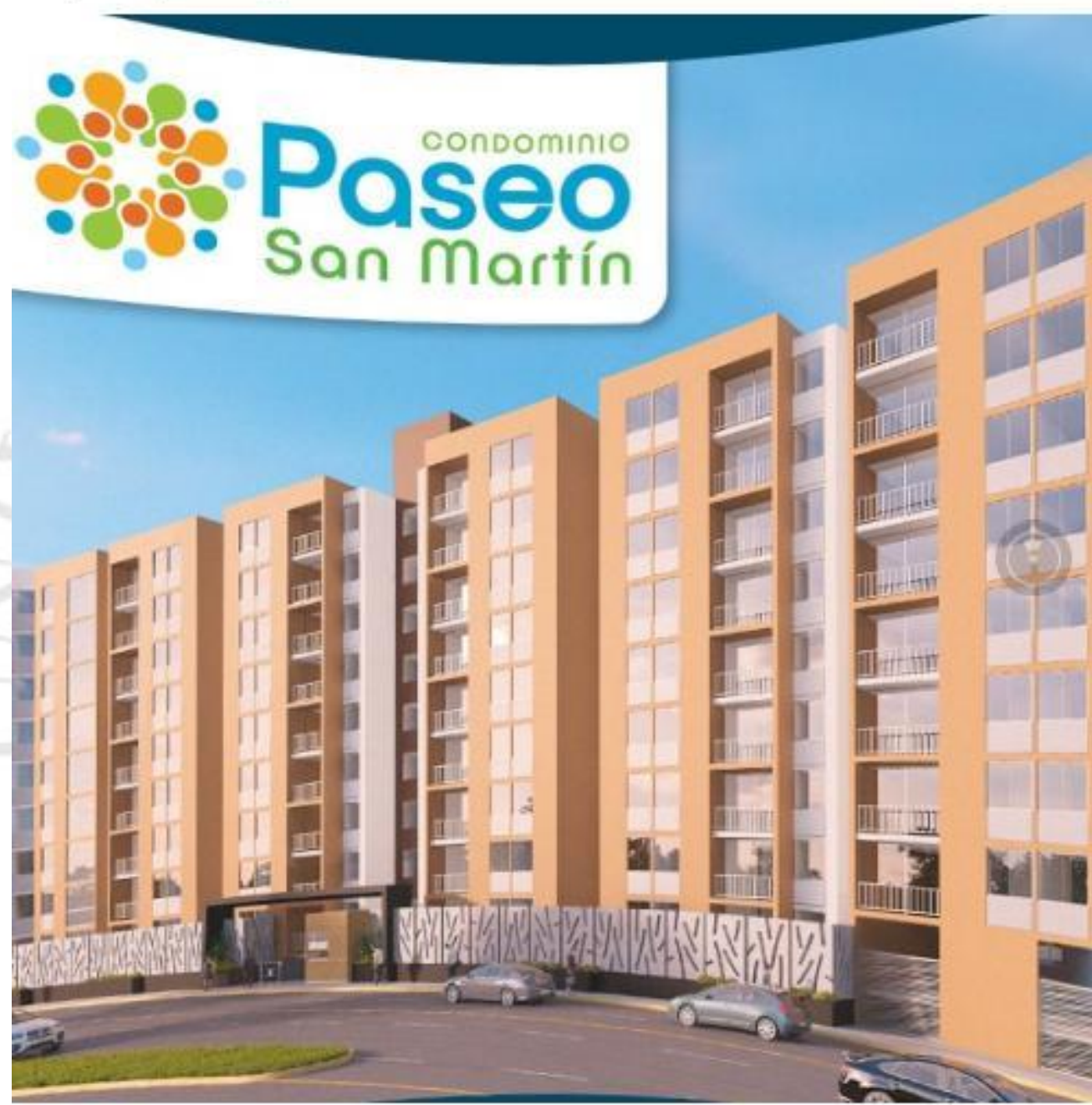

00 룽 63

10 comentarios 3 veces compartido

Figura 7: Condominio Paseo San Martín

- Ciudad Sol El Retablo

Es un proyecto muy amplió, pues comenzó en 2015 con una primera fase, pero todavía siguen vendiendo departamentos, pues han ido completando otras etapas; actualmente ya residen en las primeras etapas más de 3000 familias. Cuenta con 20 mil viviendas junto con áreas de 
comunes (ciclovía, juegos para niños, losas deportivas, gimnasio al aire libre). Son torres de 15 pisos y 8 departamentos por piso, área de 55 metros cuadrados a $S / 102,700$ y 70 metros cuadrados a $S / 218,000$.

Se encuentra ubicado en Calle Manuel González 1291 Urb. El Retablo, Comas; una desventaja, ya que es una zona que no cuenta con método de transporte cercano y que restringe el tránsito de sus propietarios a zonas relativamente cercanas al condominio.

Su comunicación pasa más por una concepción tradicional, produciendo breves spot o tomas aéreas del complejo inmobiliario. Su página web está desactualizada en términos de experiencia de usuario e información de contacto eficiente.

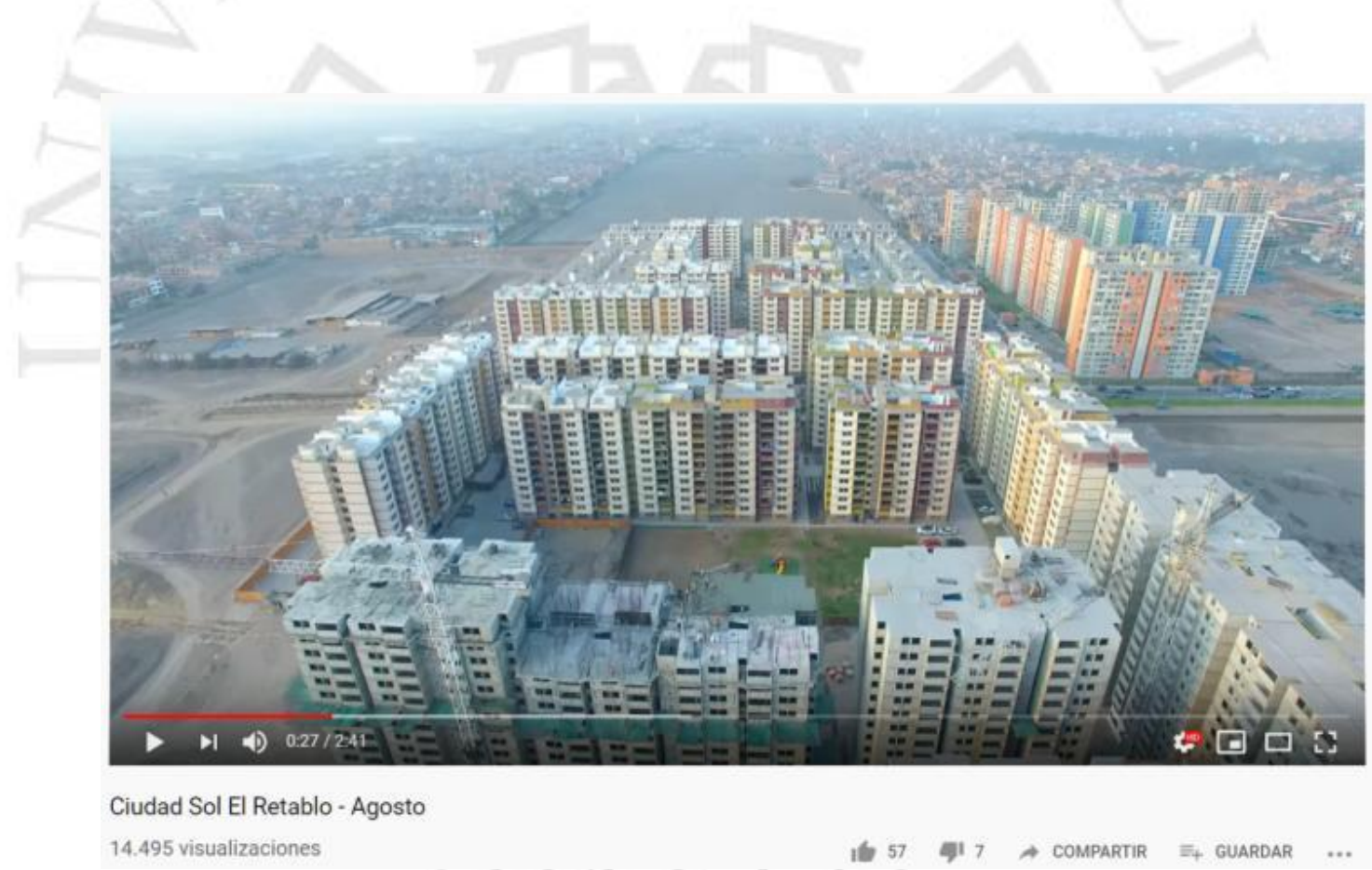

Figura 8: Screenshot video Ciudad Sol El Retablo

Sin embargo, Ciudad Sol El Retablo es la único que usa el tour virtual dentro de la competencia directa que hemos encontrado. Este widget permite al cliente potencial hacer un recorrido por los espacios el mismo estilo de Google Maps Street View. Esto es una inversión diferencial importante. 


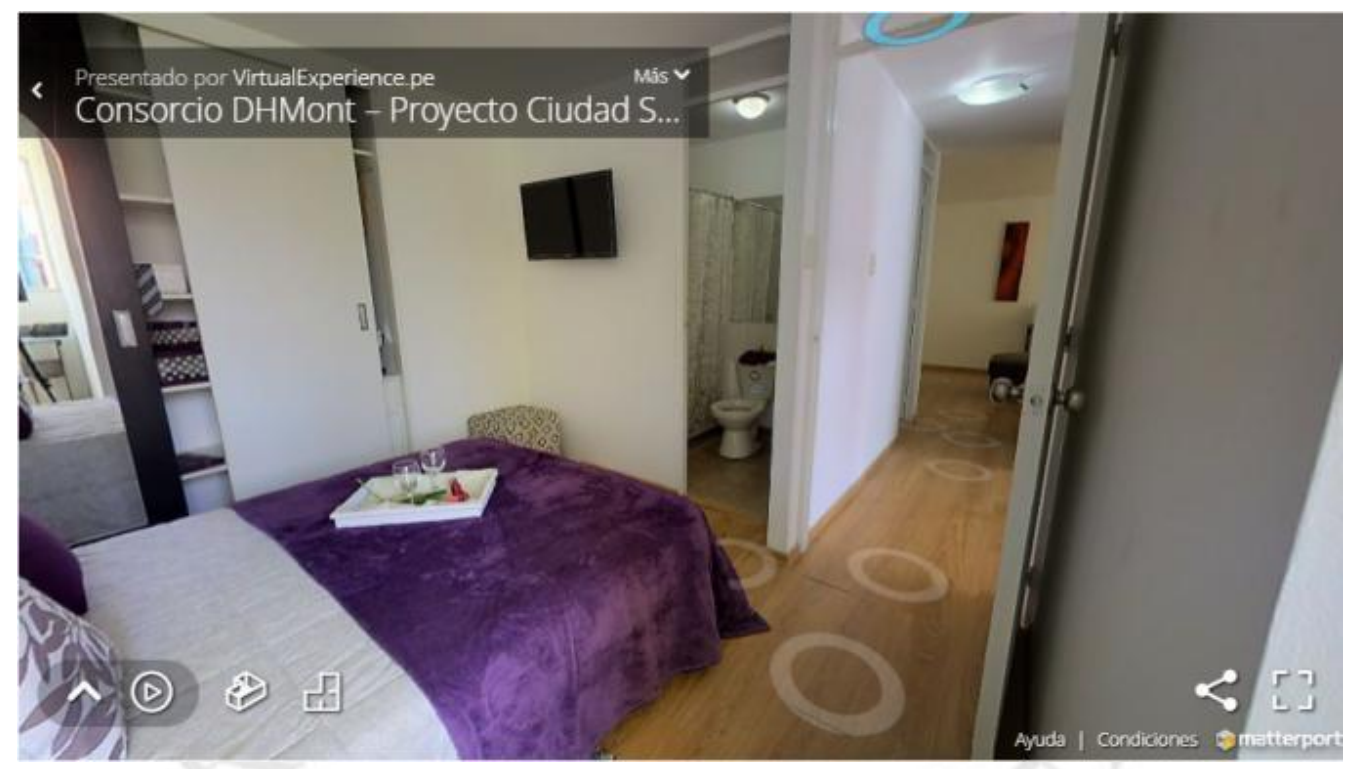

Figura 9: Tour virtual

Finalmente, solo nos queda señalar que en esta oferta de la competencia siguen cobrando importancia los fondos públicos, pues el bono del buen pagador es una motivación económica importante, que puede llegar a ahorrar S/ 13,000 a quienes adquieren su departamento (Mi casita hipotecaria, 2019)

\section{- Ciudad Verde:}

Ubicada en Carretera Panamericana Norte Km 27 - Puente Piedra, actualmente se encuentran en la construcción de la tercera etapa del condominio. Los precios van desde S/.138,318.00 soles. El financiamiento es por 20 años, con cuota inicial del 10\% y cuota mensual de S/.1,110.00 a una tasa de $9.5 \%$ del Banco de Crédito del Perú. Aplica Bono Verde de $\mathrm{S} / .4,287.92$ y Bono de Buen Pagador de S/.13,000.00. Además, pueden separarse con tan solo S/. 1, 000. Tienen excelentes acabados y el condominio es privado (por lo tanto, seguro). Además, cuenta con áreas comunes como cancha de fútbol, zona de parrillas y sala de cine. (Paz Centenario, 2019) 


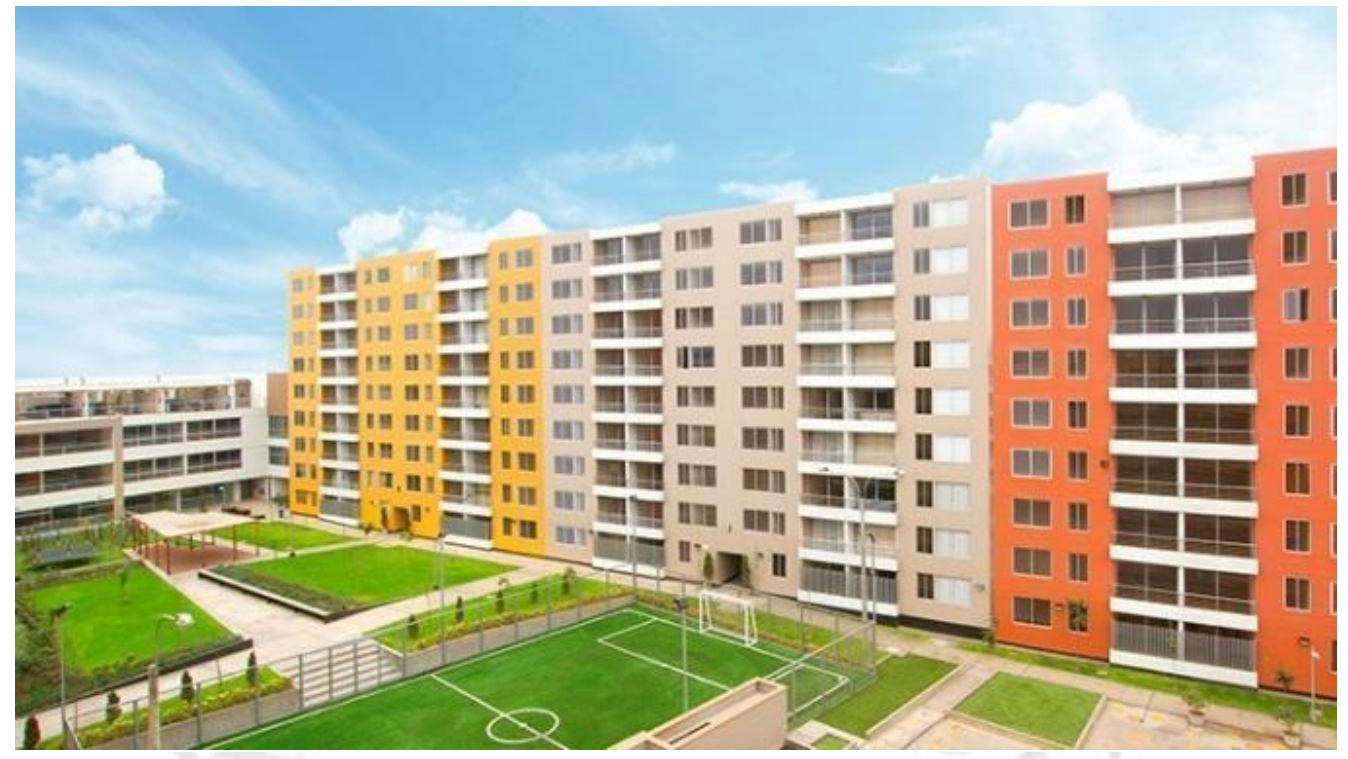

Figura 10: Ciudad Verde

- Valle Grande

Ubicado en Avenida San Juan de Dios - Puente Piedra. A un precio accesible desde $S / .105,000$ ofrece piscinas, parque interior, juegos para niños, salones de cumpleaños, gimnasio, parqueo de bicicletas, bodegas y estacionamientos, todo dentro de un condominio cerrado y seguro. Son torres de 5 pisos y departamentos de 3 dormitorios que bordean los 50 metros cuadrados. Aplicando al Bono Techo Propio, se calcula que los precios pueden ir desde los $\mathrm{S} / .71,400$ y pueden ser separados con $\mathrm{S} /$. 1, 000. La entrega está programada para marzo del 2020. 


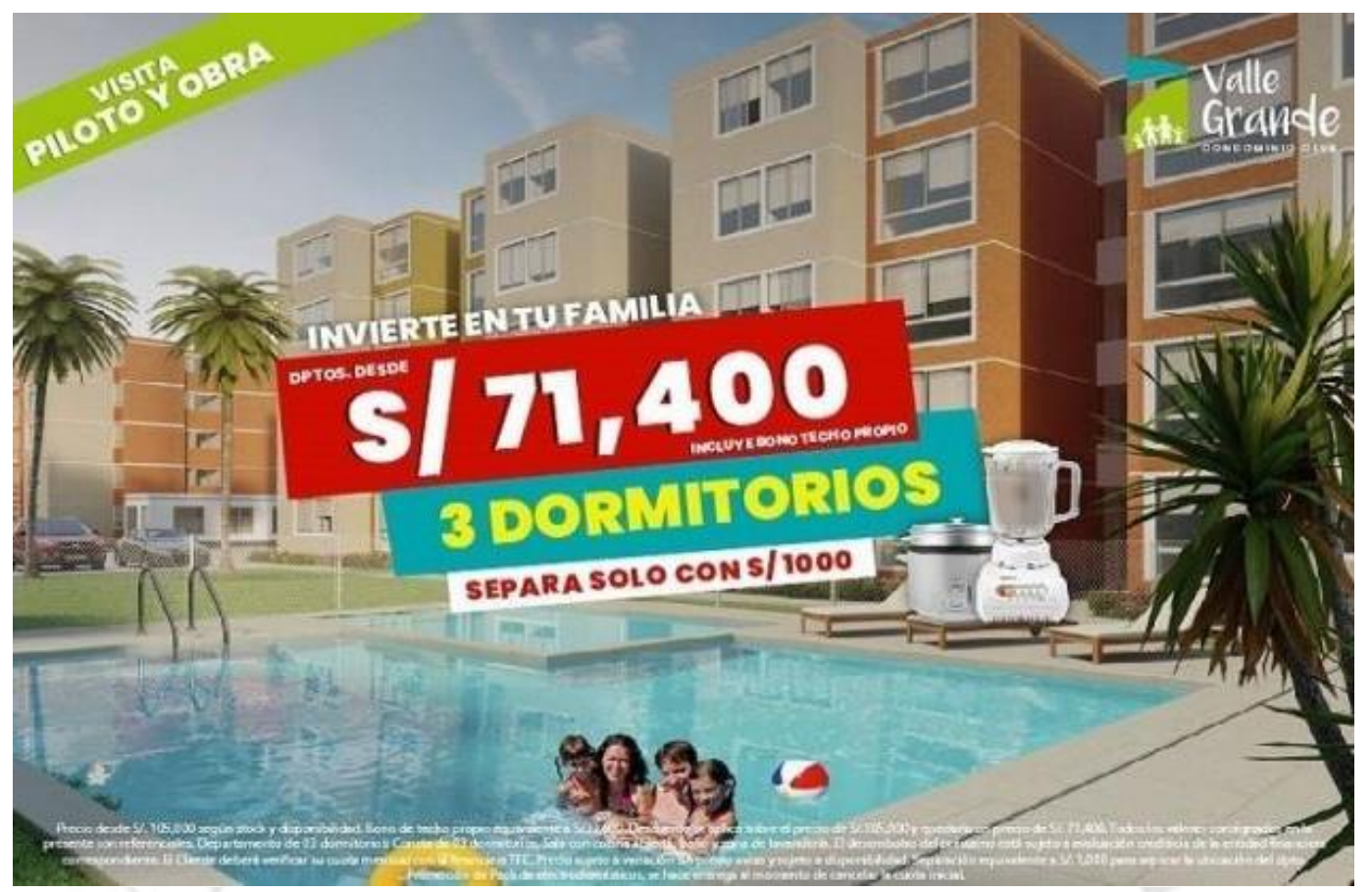

Figura 11: Oferta Valle Grande

- Prados del Sol

Se trata de un proyecto de 6 etapas de las cuales la 4ta, 5ta y 6ta acaban de ser construidas en Av. Las Torres 131 - Ate. Con excelentes áreas comunes entre las que se incluyen una cancha de fútbol, un gimnasio, una zona de parrillas y juegos para niños, cuenta con una ubicación privilegiada cerca de centros comerciales, centros de salud, parques y restaurantes. Dentro de las opciones se encuentran departamentos de 2 y 3 dormitorios (en promedio) con 60 metros cuadrados de piso laminado tipo madera en sala, comedor y dormitorios; y pisos de cerámica en baños y cocina. Los precios van desde los S/. 188, 932 y los departamentos pueden ser separados desde los S/. 1, 000. (Nexo Inmobiliario, 2018) 


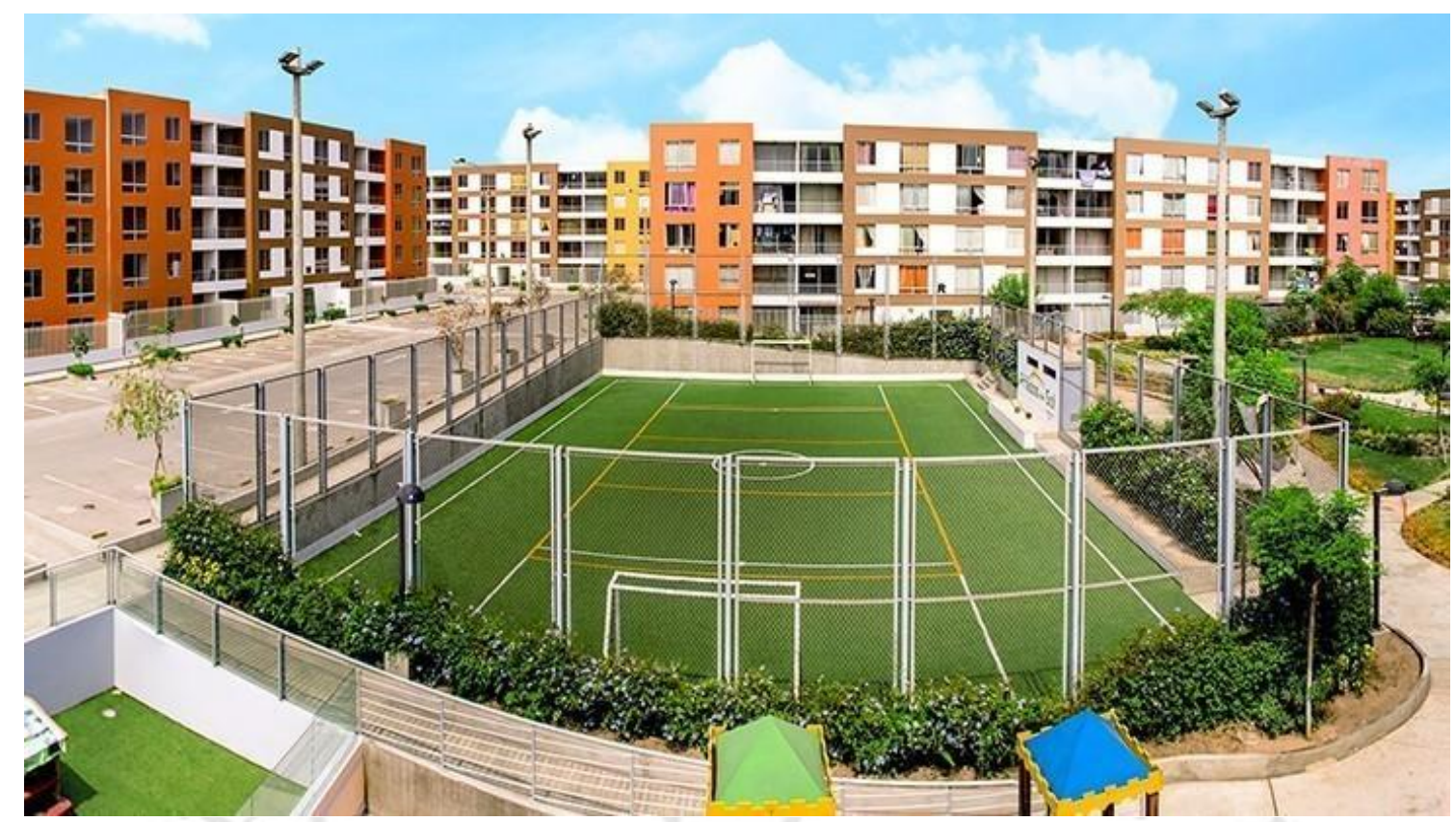

Figura 12: Prados del Sol

\section{PÚBLICO OBJETIVO}

Para la campaña que vamos a desarrollar se nos encargó que el público objetivo sea el siguiente: "jóvenes y adultos desde los 25 años de edad en adelante, de Ios NSE C y D. Todo aquel que tenga el anhelo de adquirir una vivienda propia." Además, sé indicó que "el target puede abarcar desde parejas jóvenes sin hijos, familias completas, hasta parejas mayores cuyos hijos ya no viven con ellos."

En el marco que de este requerimiento y del levantamiento de información que hemos llevado a cabo, hemos hallado que quienes tienen una marcada necesidad de independizarse y mejorar su calidad de vida son personas de 25 a 44 años (Trigoso, 2018). Así mismo, cabe resaltar que "el $58 \%$ de millennials adultos lideró las compras en el presente año, seguido por el $28 \%$ de representantes de la generación " $X$ ", y $11 \%$ de millennials jóvenes y baby boomers, respectivamente." (Mejía, 2017). Finalmente, acotamos que es la familia nuclear (padre, madre, hijos) que en un 54\% de los casos buscan comprar actualmente un departamento, aunque existe un segmento similar que viene creciendo en demanda: las parejas sin hijos que ya representan el $17 \%$ de la (Trigoso, 2018) 
Otros datos relevantes que podemos aportar como análisis de la data es que por un tema de edad quienes está más aptos para endeudarse con un préstamos que los llevará a adquirir una vivienda tienen que ser lo jóvenes adultos y justamente, son ellos los que se adaptan mejor a un perfil que puede tener todos los beneficios de los programas que ofrece el estado: personas que no tiene algún inmueble a su nombre (para el nuevo crédito de Mivivienda), que podrían adquirir un departamento calificado para el bono verde (como los de la Villa Panamericana) y que se podrían ver beneficiados con el bono del buen pagador de cumplir puntualmente con sus cuotas.

Así es que hemos tomado la decisión de segmentar al target en adultos de 25 a 45 años, millennials de los NSE C y D quienes tiene una familia con hijos o que no tiene hijos, pero están pensando en tenerlos en un futuro cercano, deseoso de independizarse y progresar en su bienestar y el de su familia con nuevas oportunidades.

Además de lo expuesto, justificamos nuestra decisión de colocar nuestros recursos en un target más segmentado como una elección estratégica. Entendemos que una comunicación planificada no puede abarcar a un público que no esté bien definido, es decir, que comparta un perfil que nos permita transmitir nuestros mensajes de marca de manera que conecte con el consumidor.

3.1 Perfil demográfico y familiar

De acuerdo a un estudio realizado por el CPI, solo en Lima Metropolitana, de 25 a 55 años hay $6,671.8$ personas. (CPI, 2019)

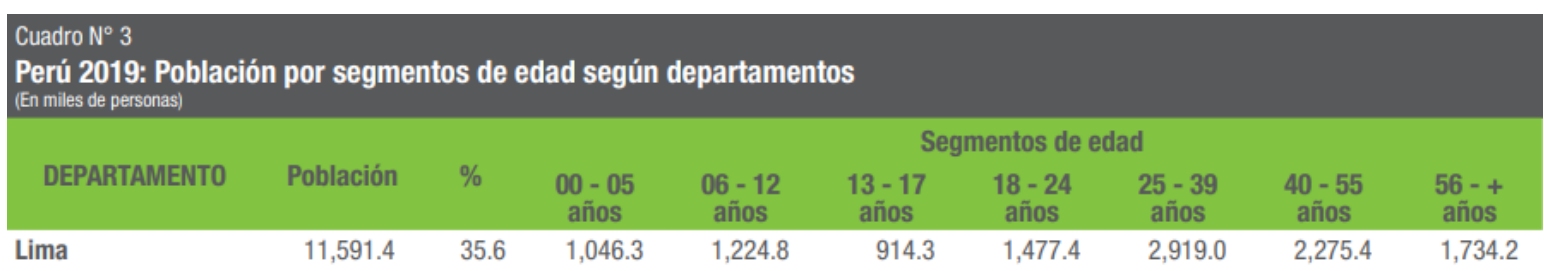

Figura 13. Perú 2019: Población por segmentos de edad según departamento 
Lima metropolitana 2019: Hogares y población por sexo y segmentos de edad según nivel socioeconómico (En miles de personas)

\begin{tabular}{|c|c|c|c|c|c|c|c|c|c|c|c|}
\hline \multirow[b]{2}{*}{ NSE } & \multicolumn{2}{|c|}{ Hogares } & \multicolumn{2}{|c|}{ Población } & \multicolumn{7}{|c|}{ Población por segmentos de edad } \\
\hline & Mls. & $\%$ & Mls. & $\%$ & $\begin{array}{c}00-05 \\
\text { años }\end{array}$ & $\begin{array}{c}06-12 \\
\text { años }\end{array}$ & $\begin{array}{l}13 \text { - } 17 \\
\text { años }\end{array}$ & $\begin{array}{c}18 \text { - } 24 \\
\text { años }\end{array}$ & $\begin{array}{c}25-39 \\
\text { años }\end{array}$ & $\begin{array}{l}40-55 \\
\text { años }\end{array}$ & $\begin{array}{c}56-+ \\
\text { años }\end{array}$ \\
\hline$A / B$ & 759.1 & 27.9 & $2,922.8$ & 27.7 & 228.9 & 272.2 & 212.8 & 355.9 & 722.0 & 604.6 & 526.4 \\
\hline C & $1,123.7$ & 41.3 & $4,507.1$ & 42.6 & 408.9 & 478.8 & 358.1 & 585.5 & 1149.5 & 880.6 & 645.7 \\
\hline D & 663.9 & 24.4 & $2,553.2$ & 24.1 & 244.3 & 282.5 & 207.8 & 337.1 & 658.0 & 488.2 & 335.3 \\
\hline E & 174.1 & 6.4 & 597.8 & 5.6 & 59.6 & 68.6 & 49.8 & 78.9 & 153.9 & 113.1 & 73.9 \\
\hline $\begin{array}{l}\text { TOTAL LIMA } \\
\text { METROPOLITANA }\end{array}$ & $2,720.8$ & 100.0 & $10,580.9$ & 100.0 & 941.7 & $1,102.1$ & 828.5 & $1,357.4$ & $2,683.4$ & $2,086.5$ & $1,581.3$ \\
\hline
\end{tabular}

FUENTE: APEIM - Estructura socioeconómica 2018

.N.E.I. - Estimaciones y proyecciones de población en base al Censo 2017

ELABORACIÓN: DEPAPTAMENTO DEESTADISTICA - C.PI.

Figura 14: Lima Metropolitana 2019: Hogares y población por sexo y segmentos de edad según nivel socioeconómico

Cuadro $\mathrm{N}^{\circ} 12$

Lima metropolitana 2019: APEIM estructura socioeconómica de la población por zonas geográficas

\begin{tabular}{|c|c|c|c|c|c|c|c|c|}
\hline & \multirow{2}{*}{ Zonas } & \multicolumn{2}{|c|}{ Población } & \multicolumn{5}{|c|}{ Estructura socioeconómica (\% horizontal) } \\
\hline & & Miles & $\%$ & A & B & C & D & E \\
\hline 1 & Puente Piedra, Comas, Carabayllo. & $1,309.3$ & 12.4 & 0.0 & 14.6 & 39.7 & 36.6 & 9.1 \\
\hline 2 & Independencia, Los Olivos, San Martin de Porras. & $1,318.3$ & 12.5 & 2.1 & 28.3 & 47.6 & 19.9 & 2.1 \\
\hline 3 & San Juan de Lurigancho. & $1,157.6$ & 10.9 & 1.1 & 21.5 & 44.6 & 25.3 & 7.5 \\
\hline 4 & Cercado, Rimac, Breña, La Victoria. & 771.2 & 7.3 & 2.5 & 29.9 & 43.9 & 21.5 & 2.2 \\
\hline 5 & $\begin{array}{l}\text { Ate, Chaclacayo, Lurigancho, Santa Anita, San Luis, El Agus- } \\
\text { tino. }\end{array}$ & $1,477.6$ & 14.0 & 1.4 & 11.6 & 45.6 & 33.3 & 8.1 \\
\hline 6 & Jesús Maria, Lince, Pueblo Libre, Magdalena, San Miguel. & 377.7 & 3.6 & 16.2 & 58.1 & 20.5 & 3.5 & 1.7 \\
\hline 7 & Miraflores, San Isidro, San Borja, Surco, La Molina. & 810.6 & 7.7 & 35.9 & 43.2 & 13.6 & 6.3 & 1.0 \\
\hline 8 & Surquillo, Barranco, Chorrillos, San Juan de Miraflores. & 878.3 & 8.3 & 2.0 & 29.1 & 48.8 & 17.3 & 2.8 \\
\hline 9 & Villa EI Salvador, Villa Maria del Triunfo, Lurin, Pachacamac. & $1,098.7$ & 10.4 & 0.5 & 7.9 & 52.2 & 31.6 & 7.8 \\
\hline 10 & $\begin{array}{l}\text { Callao, Bellavista, La Perla, La Punta, Carmen de la Legua, } \\
\text { Ventanilla y Mi Perú }\end{array}$ & $1,100.4$ & 10.4 & 1.4 & 19.0 & 46.0 & 24.4 & 9.2 \\
\hline 11 & Cieneguilla y Balnearios & 190.5 & 1.8 & 0.0 & 9.9 & 47.6 & 32.7 & 9.8 \\
\hline TOTAL & MA METROPOLITANA & $10,580.9$ & 100.0 & 4.3 & 23.4 & 42.6 & 24.1 & 5.6 \\
\hline
\end{tabular}

FUENTE: APEMM - Estructura sociooconómica 2018

ELABOAACION: DEPARTAMENTO DE ESTADISTCA - C.P1

Figura 15: Lima Metropolitana 2019. APEIM estructura socioeconómica de la población por sexo y segmento de edad según nivel socioeconómico

En un estudio de Ipsos sobre perfiles zonales en Lima Metropolitana del año pasado, se reveló que las zonas con mayor densidad poblacional son Lima Norte (25,6\%) y Lima Este (25\%). Les siguen Lima Sur (19.2\%), Lima Moderna 
(12.7\%), Callao (10.2\%) y Lima Centro (7.3\%). Los distritos con más hogares son Lima Norte, Lima Este y Lima Sur, que coincidentemente también son las zonas con un mayor porcentaje de personas con casa independiente. Dos zonas se destacan en cuanto a propiedad de un departamento dentro de un edificio: se registró un 37\% en Lima Centro y un 50\% en Lima Moderna.

Con respecto a los NSE dominantes y el ingreso promedio mensual, Lima Moderna se consolida como la zona más exclusiva al ser la zona predilecta de los niveles socioeconómicos $\mathrm{A}$ y $\mathrm{B}$ cuyo ingreso mensual del hogar bordea los S/. 8, 816. Luego está Lima Norte con un ingreso promedio de S/: 4, 355 y predominancia del sector C $(40.1 \%)$ y D $(37.5 \%)$; y Lima Centro, con más presencia del C (54.5\%) y menor porcentaje en el caso del B (25.3\%), e ingresos promedio de sus habitantes que bordean los S/. 4, 579.

En el caso de Lima Este, los ingresos mensuales ascienden a S/. 4, 173 y se registra una presencia mayoritaria del nivel D $(43.1 \%)$ por sobre el C $(36.3 \%)$. Esta misma tendencia se repite en Lima Sur (con ingresos promedio de S/. 4, $145,35 \%$ de la población NSE D y $32.8 \%$ del NSE C) y Callao (con $44 \%$ del D y $30,9 \%$ del C, así como un ingreso promedio de S/. 4, 133).

(Ipsos, 2018)

\begin{tabular}{|c|c|c|c|c|c|c|c|}
\hline Zona & $\begin{array}{c}\text { \% total } \\
\text { habitant } \\
\text { es de } \\
\text { Lima }\end{array}$ & $\begin{array}{c}\text { Númer } \\
\text { o de } \\
\text { hogar } \\
\text { es }\end{array}$ & $\begin{array}{c}\text { Tiene casa } \\
\text { independie } \\
\text { nte }\end{array}$ & $\begin{array}{c}\text { Tiene } \\
\text { dpto. en } \\
\text { edificio }\end{array}$ & $\begin{array}{c}\text { Ingreso } \\
\text { promed } \\
\text { io } \\
\text { mensu } \\
\text { al del } \\
\text { hogar }\end{array}$ & \multicolumn{2}{|c|}{$\begin{array}{c}\text { NSE } \\
\text { dominantes }\end{array}$} \\
\hline $\begin{array}{c}\text { Lima } \\
\text { Norte }\end{array}$ & $25,6 \%$ & $\begin{array}{c}601, \\
000\end{array}$ & $82 \%$ & $\begin{array}{c}\text { no } \\
\text { especifi } \\
\text { ca }\end{array}$ & $\begin{array}{c}\text { S/. 4, } \\
355\end{array}$ & $\begin{array}{c}\text { C } \\
(40.1 \\
\%)\end{array}$ & $\begin{array}{c}\text { D } \\
(37.5 \\
\%)\end{array}$ \\
\hline
\end{tabular}




\begin{tabular}{|c|c|c|c|c|c|c|c|}
\hline $\begin{array}{l}\text { Lima } \\
\text { Este }\end{array}$ & $25 \%$ & $\begin{array}{l}572, \\
000\end{array}$ & $85 \%$ & $\begin{array}{c}\text { no } \\
\text { especifi } \\
\text { ca }\end{array}$ & $\begin{array}{c}S / .4 \\
173\end{array}$ & $\begin{array}{c}\text { C } \\
(36.3 \\
\%)\end{array}$ & $\begin{array}{c}D \\
(43.1 \\
\%)\end{array}$ \\
\hline $\begin{array}{l}\text { Lima } \\
\text { Centro }\end{array}$ & $12,7 \%$ & $\begin{array}{l}256, \\
000\end{array}$ & $43 \%$ & $37 \%$ & $\begin{array}{c}\text { S/: } 4 \\
579\end{array}$ & $\begin{array}{c}\text { B } \\
(25.3 \\
\%)\end{array}$ & $\begin{array}{c}\text { C } \\
(54.5 \\
\%)\end{array}$ \\
\hline $\begin{array}{c}\text { Lima } \\
\text { Moder } \\
\text { na }\end{array}$ & $7,3 \%$ & $\begin{array}{l}396 \\
000\end{array}$ & $43 \%$ & $50 \%$ & $\begin{array}{c}\text { S/. 8, } \\
816\end{array}$ & $\begin{array}{c}\text { A } \\
(33.1 \\
\%)\end{array}$ & $\begin{array}{c}\text { B } \\
(52.4 \\
\%)\end{array}$ \\
\hline $\begin{array}{l}\text { Lima } \\
\text { Sur }\end{array}$ & $19,2 \%$ & $\begin{array}{l}452, \\
000\end{array}$ & $93 \%$ & $\begin{array}{c}\text { no } \\
\text { especifi } \\
\text { ca }\end{array}$ & $\begin{array}{c}\text { S/: 4, } \\
145\end{array}$ & $\begin{array}{c}C \\
(32.8 \\
\%)\end{array}$ & $\begin{array}{c}\text { D } \\
(35 \%)\end{array}$ \\
\hline Callao & $10,2 \%$ & $\begin{array}{l}259, \\
000\end{array}$ & $84 \%$ & $\begin{array}{c}\text { no } \\
\text { especifi } \\
\text { ca }\end{array}$ & $\begin{array}{c}S /: 4, \\
133\end{array}$ & $\begin{array}{c}C \\
(30.9 \\
\%)\end{array}$ & $\begin{array}{c}D \\
(44 \%)\end{array}$ \\
\hline
\end{tabular}

Tabla 1: Cuadro de elaboración propia tomando los datos de Ipsos 2018.

Según dos estudios de Ipsos del 2018, nos podemos enfocar en dos perfiles: el "Perfil del adulto joven peruano" que se centra en los hombres y mujeres entre 21 y 35 años de todos los niveles socioeconómicos de las 11 principales ciudades del Perú Urbano; y el "Perfil del adulto peruano 2018", en el que se entrevistó a hombres y mujeres de 36 a 59 años de todos los niveles socioeconómicos de las principales ciudades del Perú. (Ipsos, 2018)

En el caso de los adultos jóvenes, se calcularon 6.7 millones de adultos en el Perú, de los cuales 2.7 millones se ubican en Lima. Se calcula que el $57 \%$ de ellos tiene hijos, que un $39 \%$ es jefe del hogar y que un $52 \%$ vive aún en la casa familiar (Ipsos, 2018).

Por otro lado, en el caso de los adultos se estima que alcanzan los 7.3 millones en el Perú, de los cuales solo 3.1 millones se encuentran en Lima. Se calcula 
que tienen en promedio 46 años y que cuentan con una pareja. Además, 9 de cada 10 son padres y tienen aproximadamente dos hijos.

(Ipsos, 2018)

\subsection{Perfil laboral}

Se estima que el $61 \%$ de los jóvenes adultos se desempeña como trabajador dependiente mientras que el $22 \%$ es independiente. Aunque el $84 \%$ de ellos se encuentra laborando actualmente, de esta cifra se detalla que un $37 \%$ se desempeña en algo diferente a lo que ha estudiado; un $36 \%$ sí ejerce lo que ha estudiado, y un $26 \%$ no ha logrado estudiar aún. Un dato interesante que vale la pena mencionar es que un $87 \%$ de los encuestados se encontraban satisfechos con su trabajo: $83 \%$ dentro del entorno laboral y $67 \%$ al momento de recibir su sueldo (Ipsos, 2018).

En el caso de los adultos, un 38\% ha logrado culminar sus estudios secundarios, pero tan solo 1 de cada 3 ha conseguido terminar sus estudios superiores. Además, el $99 \%$ concordó que es importante tener un trabajo, pero solo un $84 \%$ se encuentra trabajando actualmente: 5 de cada 10 se desempeñan como trabajadores dependientes, y 3 de cada 10 se desenvuelven como independientes. (Ipsos, 2018)

\subsection{Perfil económico y financiero}

Según un estudio reciente de Ipsos, el ingreso mensual promedio de los hogares de Lima Metropolitana es de S/. 4, 470, con gastos que ascienden hasta los S/. 3, 410 al mes. (Ipsos, 2019)

En promedio, el ingreso mensual de los jóvenes adultos bordea los $S / 1,200$ mensuales. El 79\% ahorra con el objetivo de comprarse un inmueble o para invertir en negocios, sin embargo, solo el 39\% está bancarizado.

(Ipsos, 2018). La principal fuente de ingresos de los adultos es el salario quincenal o mensual; 6 de cada 10 ahorran y 2 de cada 5 son bancarizados. (Ipsos, 2018). 


\subsection{Entretenimiento y consumo de medios}

Según un estudio reciente de Ipsos sobre el consumo de medios, en cuanto a alcance y tiempo de consumo, uno de los datos más destacados es que el consumo diario de medios tradicionales en el Perú urbano llega al $90 \%$, mientras que solo el $65 \%$ consume diariamente medios digitales. La TV abierta es el medio con mayor alcance con un $64 \%$ de consumo diario. Le siguen la radio $(45 \%), \mathrm{OOH}(44 \%)$, punto de venta $(38 \%)$ y canales nacionales de cable $(35 \%)$. (Ipsos, 2018)

Es así como, América y Latina son las marcas líderes de entretenimiento. En cuanto al ámbito informativo, lidera RPP TV. RPP también lidera a nivel de radios informativas, seguida por Exitosa. En el caso de radios musicales, no se puede precisar por la variedad de gustos, pero según un estudio del 2017 sobre audiencias radiales, dentro del NSE C, las radios más populares son RPP, Moda y La Karibeña. Siendo Moda la más popular dentro del grupo etario de 17 a 25 años, seguida de La Karibeña dentro del grupo que comprende desde los 16 hasta los 37 años; y RPP, preferida por oyentes de 38 años a más. (CPI, 2017)

Sobre los periódicos, el estudio precisa que, en el aspecto informativo, El Comercio encabeza la lista, seguido por La República. Correo y Perú.21 se destacaron por su popularidad en el factor calidad-precio.

Trome lidera el mercado de los periódicos populares, mientras que Libero y Dépor son los más leídos en cuanto a contenido deportivo.

Sin embargo, a pesar de que los medios tradicionales ocupan el $55 \%$ del consumo total, el nivel socioeconómico es un factor determinante. En el A, B y $C$ los medios digitales llegan al 55\% del consumo, mientras que en $D$ y $E$ alcanzan un $33 \%$.

Con respecto a los medios digitales, Facebook es la red social con mayor alcance con un $69 \%$ de consumo semanal. En segundo lugar, están las 
búsquedas de Google (59\%), YouTube (58\%) y las webs de noticias (42\%). (Ipsos, 2018)

Según un estudio CPI sobre el uso de redes sociales en Lima, desde el 2013 hasta el 2018 se ha registrado un incremento de usuarios pertenecientes a los NSE C, D y E. En cuanto a generaciones, podemos apreciar que la Generación " $Y$ " encabeza la lista, seguida de un incremento significativo de usuarios nuevos pertenecientes a la Generación "X. (CPI, 2019)

$\mathrm{Si}$ detallamos los usuarios por cada una de las redes sociales según generaciones, vemos que, en el caso de los millenials, Facebook ocupa un $91.1 \%$, Instagram un $41.6 \%$ y Twitter un $21.4 \%$, siendo esta generación la que más consume cada uno de estos medios. (CPI, 2019)

Es así como se concluye que, gracias a la penetración de internet, los medios digitales gozan de una presencia importantes. Un 69\% de los encuestados afirmaron conectarse a internet a diario, sin embargo, la fuerza de los medios tradicionales sigue siendo mayor. (Ipsos, 2018)

a internet a diario, sin embargo, la fuerza de los medios tradicionales sigue siendo mayor. (Ipsos, 2018)

Gracias al incremento de la penetración de internet, los medios digitales tienen una presencia importante dentro del share de medios. Sin embargo los medios tradicionales aún lideran en el share de medios.

\section{CONSUMO DE MEDIOS - EXPOSICIÓN}
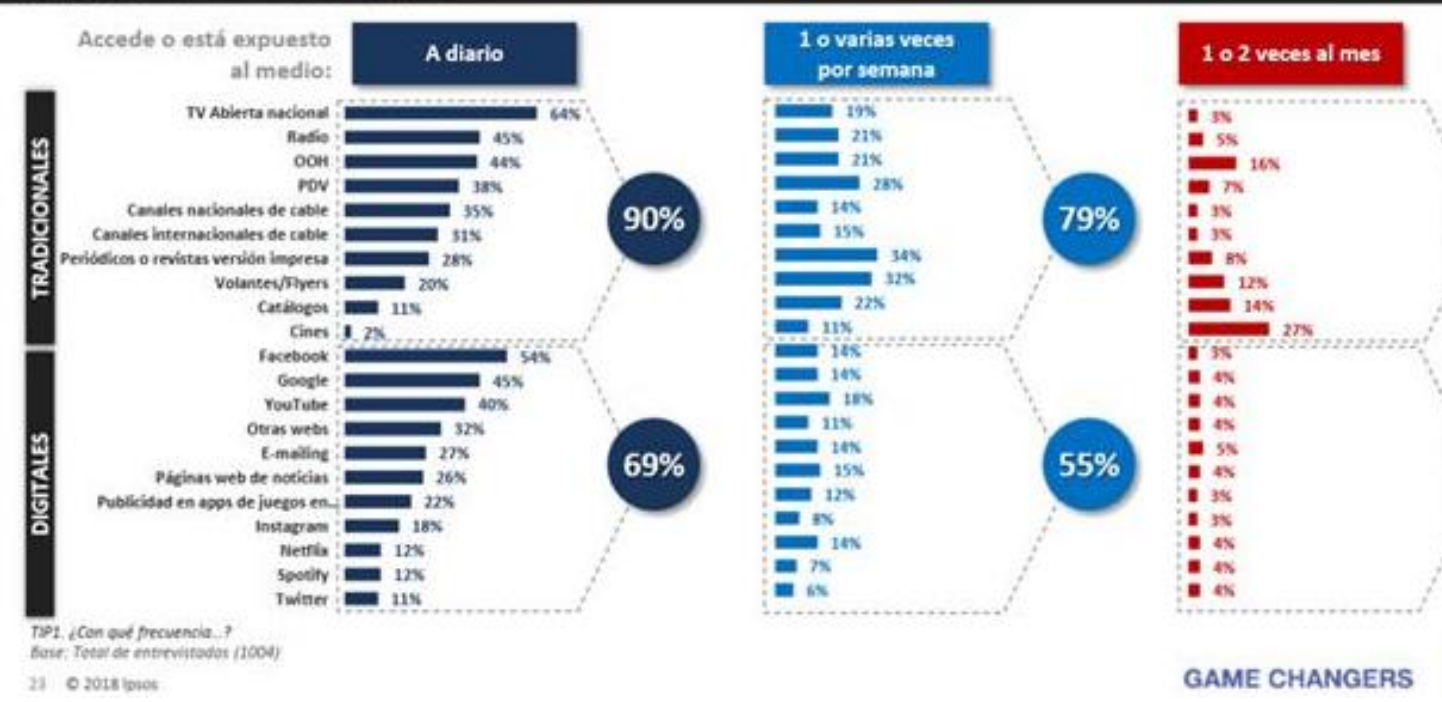
Figura 16: Consumo de medios - Exposición 2018.

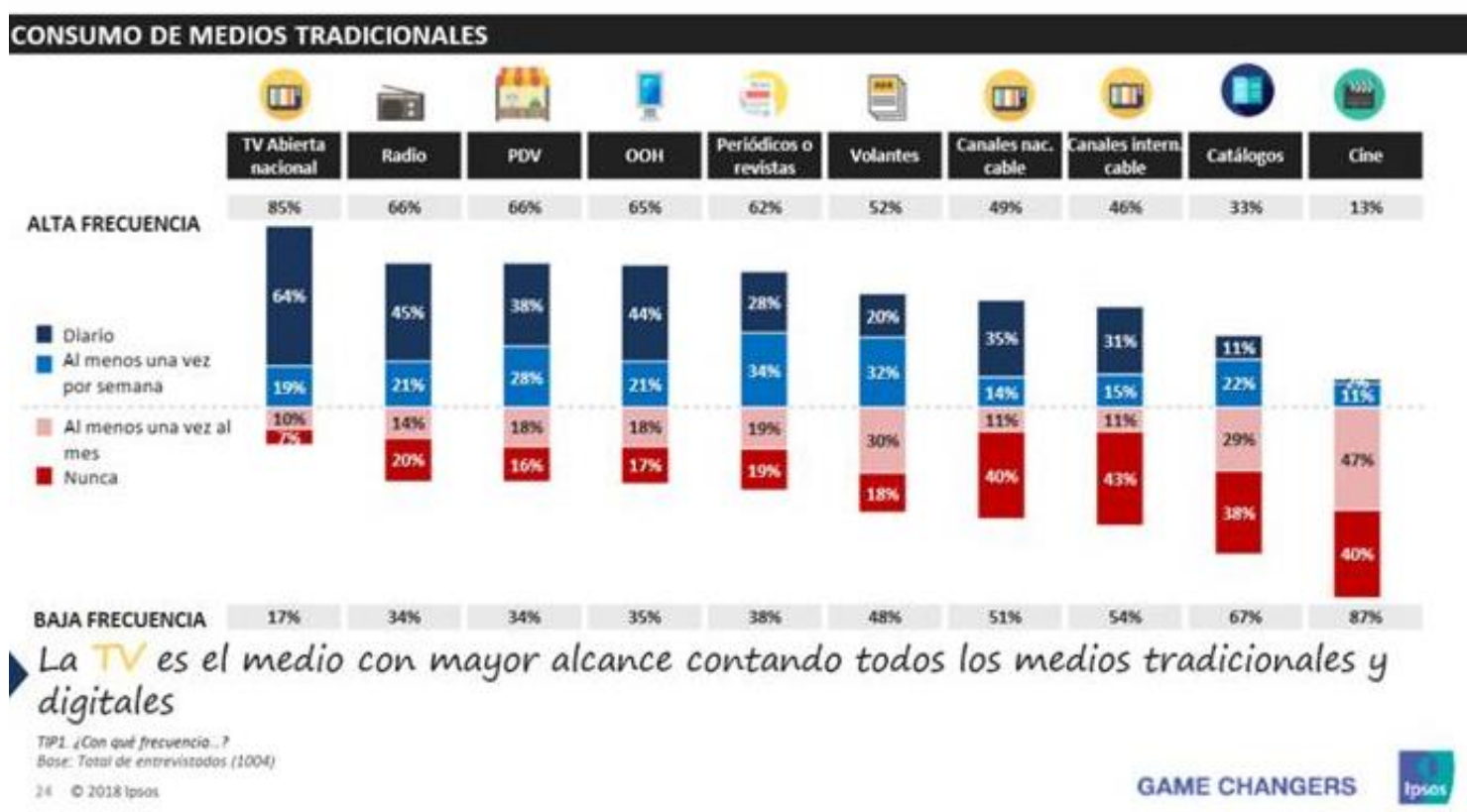

Figura 17: Consumo de medios tradicionales

Con respecto al consumo de medios en el mercado inmobiliario, según la ASEI, el $48.25 \%$ de los clientes potenciales consulta portales por internet para comprar un inmueble en contraposición a un $14 \%$ que recurre a redes sociales para obtener información. Sin embargo, solo el $11 \%$ acude a la empresa inmobiliaria. (Diario Correo, 2018)

\subsection{Comportamiento tecnológico}

En un perfil elaborado por Ipsos, el "celunauta" peruano tiene en promedio 36 años, es trabajador dependiente y pertenece al NSE C. Principalmente utiliza su celular para recibir llamadas y chatear, y acostumbra usarlo por las tardes y noches. (Ipsos, 2017)

En otro estudio de Ipsos que salió en una nota de Gestión, las aplicaciones más usadas por el smartphonero adulto son Facebook y WhatsApp, cada una con un 35\%. (Ipsos, 2018) 


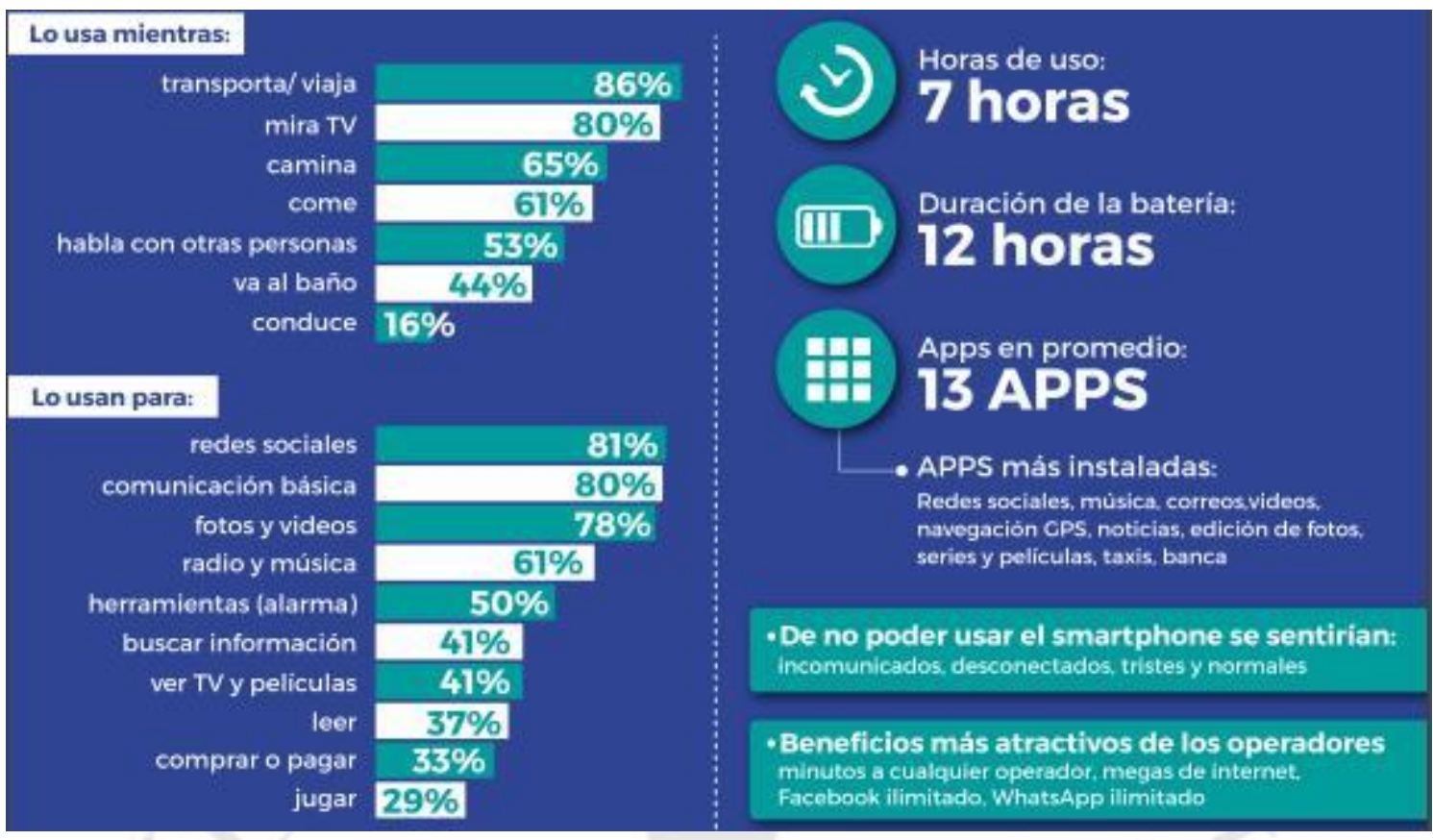

Figura 18: Uso de smartphones en el Perú

Sobre el uso de los smartphones focalizado en el Perú, se mostró que los peruanos usan sus teléfonos inteligentes aproximadamente 7 horas diarias. El uso principal lo ocupan las redes sociales (81\%), seguidas por la necesidad de comunicarse $(80 \%)$ y para fotos y videos $(78 \%)$. Por otra parte, los momentos de más uso son durante el transporte diario (86\%), mientras se mira la televisión (80\%), al caminar (65\%) y durante las comidas (61\%). (Ipsos, 2017)

\subsection{Comportamiento de consumo}

De acuerdo con Ipsos, los adultos peruanos consideran como principal actividad de entretenimiento ver televisión (63\%), seguido de salir a comer fuera del hogar (38\%). (Ipsos, 2018)

En el 2018, la revista ANDA publicó un artículo de Javier Álvarez Pecol, Director de Estudios Multiclientes, en el que habla sobre el retail en el Perú. En este estudio, se revela que los lugares de mayor concurrencia habitual son las bodegas (96\%), seguidas por los mercados (92\%), centros comerciales $(74 \%)$ y supermercados $(72 \%)$. 


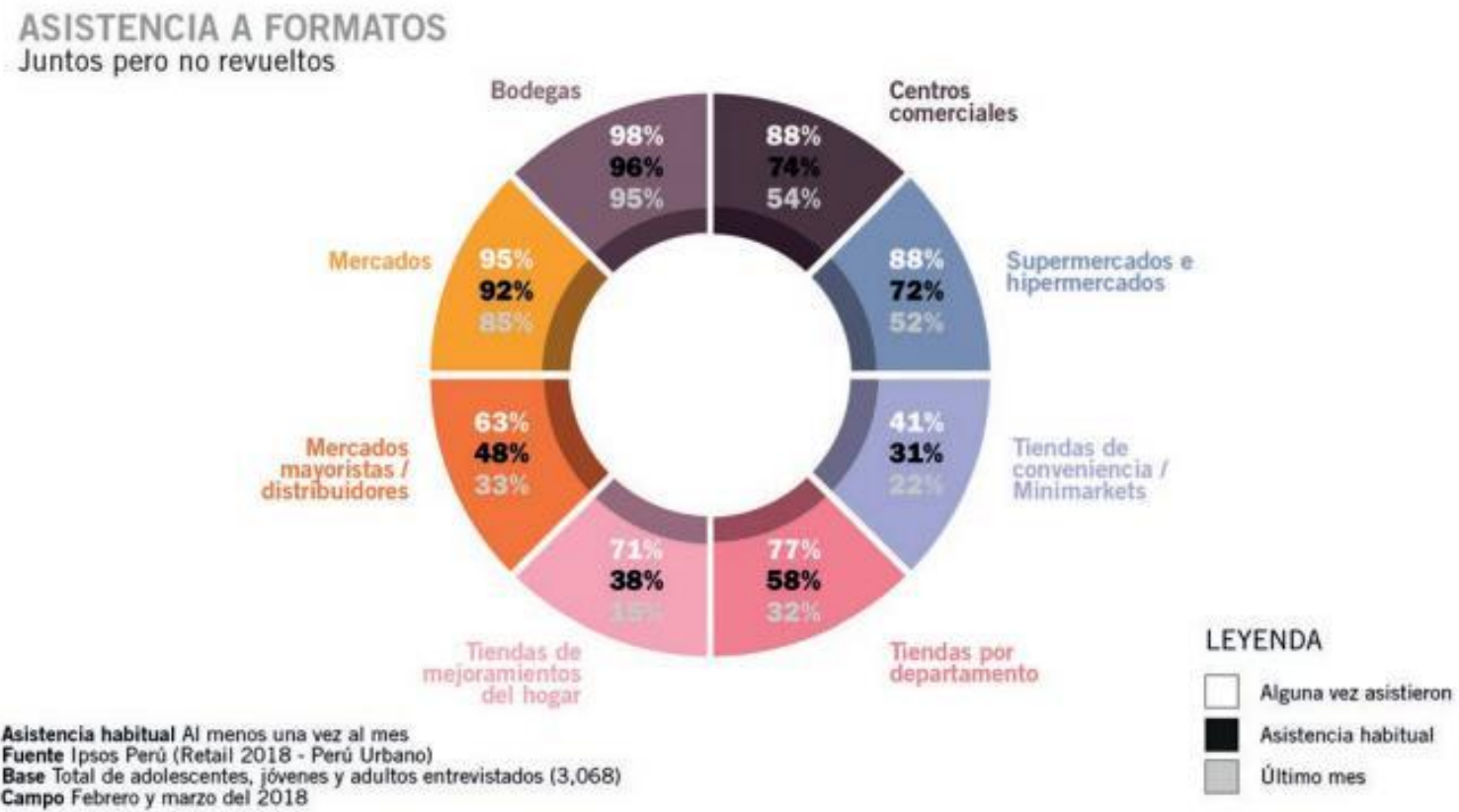

Figura 19: Asistencia a formatos

En cuanto a tiendas de forma particular, en la categoría de supermercados los más visitados son Plaza Vea y Tottus; en la categoría de tiendas por departamento Saga Falabella es la más popular, mientras que en tiendas de mejoramiento del hogar las más visitadas son Maestro y Sodimac (Álvarez, 2018).

ASISTENCIA A TIENDAS

Las grandes superficies son las más visitadas

\section{LEYENDA}

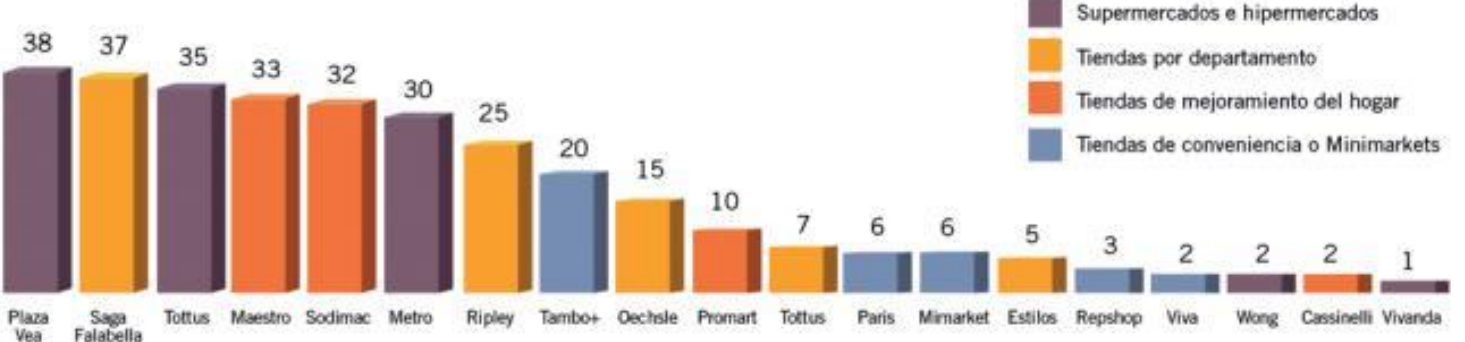

\section{LIMA (\%)}

\begin{tabular}{|c|c|c|c|c|c|c|c|c|c|c|c|c|c|c|c|c|c|c|}
\hline 45 & 48 & 38 & 34 & 42 & 43 & 37 & 49 & 13 & 10 & 6 & 8 & 5 & 1 & 4 & 2 & 4 & 2 & 2 \\
\hline
\end{tabular}

Fuente Ipsos Perú (Retail 2018 - Perú Urbano)

Base Total de adolescentes, jóvenes y adultos entrevistados $(3,068)$

Figura 20: Asistencia a tiendas 
Sobre los centros comerciales más recordados en Lima, tenemos en primer lugar a Mega Plaza (35\%), seguido de Jockey Plaza (25\%), Plaza Norte Independencia (20\%), Mall Aventura Plaza (11\%), Mall del Sur (10\%), entre otros.

\section{Centros comerciales más recordados}

\begin{tabular}{l|c|}
\hline $\begin{array}{l}\text { En Lima } \\
\text { (Principales menciones) }\end{array}$ & $\mathbf{\%}$ \\
\hline MegaPlaza & $\mathbf{3 5}$ \\
\hline Jockey Plaza & $\mathbf{2 5}$ \\
\hline Plaza Norte - Independencia & $\mathbf{2 0}$ \\
\hline Mall Aventura Plaza - & $\mathbf{1 1}$ \\
\hline Santa Anita & \\
\hline Plaza San Miguel & $\mathbf{1 0}$ \\
\hline Mall del Sur - San Juan de & $\mathbf{1 0}$ \\
\hline Miraflores & \\
\hline Plaza Lima Sur & $\mathbf{9}$ \\
\hline Real Plaza Centro Civico & $\mathbf{9}$ \\
\hline Open Plaza Atocongo - SJM & $\mathbf{7}$ \\
\hline Mall Aventura Plaza & $\mathbf{7}$ \\
\hline Bellavista - Callao & \\
\hline Fuente: lpsos Pent & \\
\hline
\end{tabular}

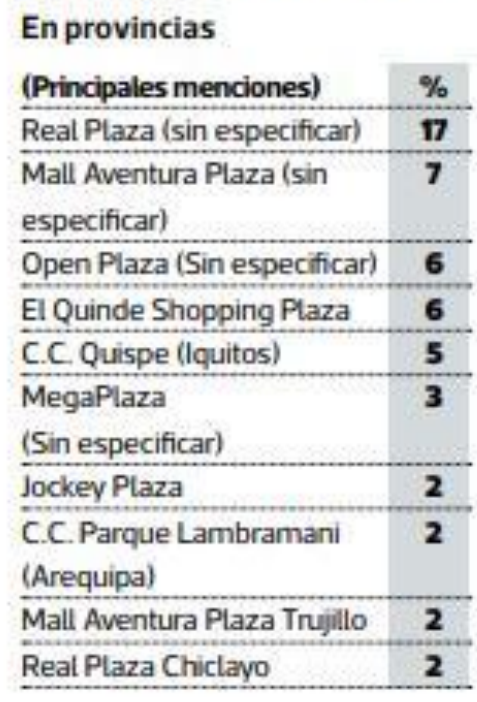

Figura 21. Centros comerciales más recordados

Además, el estudio especifica que un $60 \%$ de la generación $X$ quiere centros comerciales más cerca a sus hogares. Según el estudio, 6 de cada 10 adultos posee una vivienda propia, y el $42 \%$ del segmento tiene intenciones de adquirir un inmueble en los próximos dos años (2018 y 2019 considerando que el estudio fue realizado en el 2017). Por otro lado, el $44 \%$ de las personas que alquilan una vivienda actualmente piensan comprar una propiedad (Ipsos, 2017)

\subsection{Los Buyer Persona}

\begin{tabular}{|l|l|l|}
\hline Buyer persona & Diana Rojas & Edwin Flores \\
\hline
\end{tabular}




\begin{tabular}{|c|c|c|}
\hline $\begin{array}{l}\text { Contexto } \\
\text { personal }\end{array}$ & $\begin{array}{l}\text { Diana vive con su pareja en } \\
\text { casa de sus padres en Lima } \\
\text { Sur. Tiene un hijo de } 2 \text { años } \\
\text { de edad. }\end{array}$ & $\begin{array}{l}\text { Edwin está casado. Tiene } 2 \\
\text { hijos: uno de } 8 \text { con } \\
\text { discapacidad motora y la otra } \\
\text { de } 5 \text { sin ninguna discapacidad. } \\
\text { Actualmente alquila un } \\
\text { departamento en Lima Norte. }\end{array}$ \\
\hline $\begin{array}{l}\text { Datos } \\
\text { demográficos } \\
\text { y financieros }\end{array}$ & $\begin{array}{l}\text { Tiene } 28 \text { años y es } \\
\text { enfermera. Su pareja } \\
\text { también trabaja y es técnico } \\
\text { farmacéutico. En conjunto } \\
\text { perciben } S / .3,500 \text { al mes. }\end{array}$ & $\begin{array}{l}\text { Tiene } 39 \text { años y es contador. } \\
\text { Su pareja es profesora de } \\
\text { educación primaria. } \\
\text { conjunto ganan } S / .4,000 \text { al } \\
\text { mes. }\end{array}$ \\
\hline Metas y retos & $\begin{array}{l}\text { El cuarto que comparte con } \\
\text { su pareja ya les queda chico } \\
\text { y vivir en casa de sus padres } \\
\text { fue una solución temporal. } \\
\text { Tienen el sueño de la casa } \\
\text { propia, pero a diferencia de } \\
\text { sus padres que construyeron } \\
\text { su casa por cuenta propia, } \\
\text { ellos no son constructores. }\end{array}$ & $\begin{array}{l}\text { Con } 2 \text { hijos en crecimiento, } \\
\text { necesitan espacio } \\
\text { recreacional seguro. Han } \\
\text { llegado al punto en el que, lo } \\
\text { que gastan en el alquiler es } \\
\text { más o menos la misma } \\
\text { cantidad que pueden invertir } \\
\text { en la hipoteca mensual de un } \\
\text { departamento. Además, } \\
\text { desean un lugar que cubra las } \\
\text { necesidades especiales de su } \\
\text { hijo. }\end{array}$ \\
\hline Valores & $\begin{array}{l}\text { Son ahorradores y } \\
\text { visionarios. Desean } \\
\text { independizarse }\end{array}$ & $\begin{array}{l}\text { Son unidos y desean dejarles } \\
\text { una herencia a sus hijos que }\end{array}$ \\
\hline
\end{tabular}




\begin{tabular}{|l|l|l|}
\hline & $\begin{array}{l}\text { definitivamente y tomar el } \\
\text { siguiente paso. }\end{array}$ & $\begin{array}{l}\text { realmente puedan aprovechar. } \\
\text { Un hogar. }\end{array}$ \\
\hline
\end{tabular}

Tabla 2: Cuadro de elaboración propia para buyers persona.

4. LA MARCA

\subsection{Declaración de Posicionamiento}

La Villa Panamericana es el sueño de la vivienda propia accesible para las familias limeñas que buscan independencia y un ambiente positivo en el cual desarrollarse.

\subsection{Promesa}

Una vivienda de calidad en la que las familias podrán mejorar su calidad de vida, con el precio más competitivo del mercado y con todas las facilidades de financiamiento y bonos de pago.

\subsection{Ventaja diferencial}

- Mejor relación precio calidad del mercado inmobiliario.

- Un ambiente positivo único en su tipo.

\subsection{Reason why}

- El financiamiento y el precio 
Los departamentos de la Villa de Atletas se venderán a través del Nuevo Crédito Mivivienda, para todos lo que califiquen (nuestro target). Además, aplicarán el Bono Verde y el Bono del Buen Pagador. Sumando los beneficios, para las personas que puedan aplicar todo los anteriores el precio base puede estar en $\mathrm{S} / 148,461.54$

Estas viviendas aplican para el Bono Verde; es decir, que tienen la certificación Mivivienda Verde. Esto quiere decir que los departamentos incluyen características en su diseño y construcción de ahorro energético. Cuentan con sistemas de iluminación de bajo consumo y ahorro de agua a través de sistemas de filtrado para el riego de las áreas verdes con fuentes de agua reutilizables.

- La infraestructura de calidad

El diseño de la Villa Panamericana y su construcción tienen la certificación de Mivivienda Verde, lo cual quiere decir que cumple con altos estándares de eficiencia energética, manejo de desechos y ahorro de agua. Esto implica que los departamentos incluyen sistemas de ahorro en el consumo de la iluminación y el reciclaje de sus aguas, las cuales se filtran y se vuelven a usar en las áreas verdes. Así mismo, la Villa es un complejo habitacional totalmente con infraestructura destacable para el uso común: comedor, oficinas administrativas, Policlínico, Iglesia, Centro Cultural, Gimnasio, Anfiteatro, una pista de jogging y canchas deportivas.

El espacio de integración social, llamado "la casa club", es conformado por tres salas multiusos, una sala de juego para jóvenes, una sala de juego para niños y un gimnasio.Como complemento, las zonas de esparcimiento incluyen dos losas deportivas multiusos y una ciclovía de 1 $\mathrm{km}$.

Cabe resaltar la importante tarea que se llevó a cabo al volver a este complejo el primer condominio pensado en para darle facilidades a las 
personas que sufren de alguna discapacidad física. Los 7 edificios cuentan con los parámetros adecuados para que estas personas puedan movilizarse con facilidad e incluso cuentan con señalización en lenguaje braille.

- Un ambiente positivo para una familia

Muchos de los deportistas panamericanos y parapanamericanos que ganaron una medalla irán a vivir en la Villa junto a su familia. Con lo cual las personas que consideren adquirir un departamento en la Villa Panamericana ya tiene una idea de quienes serán sus vecinos: nada más y nada menos que deportistas altamente capacitados, personas que han puesto en alto el nombre de nuestro país y que lo seguirán haciendo. Esto combinado con la infraestructura, puede acentuar la percepción positiva, pues poder practicar deporte aporta al bienestar de las familias.

Finalmente, lo que debe representar esta edificación es algo de lo que todos los peruanos podemos estar orgullosos: una marca importante de los logros que obtuvimos como anfitriones de los juegos Panamericanos y Parapanamericanos Lima 2019.

\subsection{Tono de comunicación}

Para comunicarnos con nuestro target vamos a usar los valores que ellos buscan desarrollar con sus familias: crecimiento personal, bienestar familiar, independencia y seguridad. En ese marco, utilizaremos todas las herramientas a nuestra disposición para asegurar confianza e inspirar a nuestros posibles consumidores. La idea es generar empatía, conexión y deseo de ser mejores cada día. Siempre comunicándonos en su lenguaje, hablándoles de tú a tú y prestando un servicio de venta y postventa de calidad. 
Misión: Brindar un hogar de calidad único en su tipo a las familias limeñas que buscan mejorar su calidad de vida con nuevas oportunidades para ellos.

Visión: Ser el condominio habitacional inclusivo y ecológico en Lima Metropolitana.

\section{IDENTIDAD CORPORATIVA}

La identidad corporativa es un factor interno y controlable por la empresa, que se proyecta para generar una impresión (imagen). Es fundamental la coherencia, para crear una imagen sólida de la empresa y generar confianza.

\subsection{Nombre}

Muchos medios de comunicación se refieren al condominio con diferentes nombres, tales como: Villa de Atletas, Villa Panamericana y Parapanamericana, y Villa Deportiva. De acuerdo a decretos legislativos emitidos en el diario oficial "El Peruano" y a través de medios nacionales e internacionales, sabemos que el nombre oficial para referirnos a la obra es Villa Panamericana, por lo que será conservado como parte del legado.

\subsection{Logotipo de la marca}

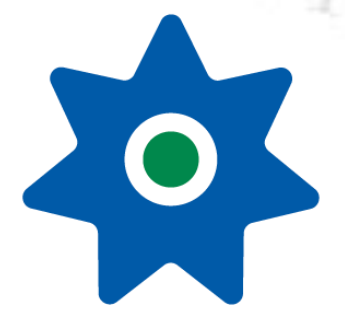

\section{VILLA PANAMERICANA}

5.3 Tipografía: Exo 2.0 


\section{ABCDEFGHIJKLMNOPQRSTUVWXYZ abcdefghijklmnopqrstuvwxyz 0123456789.,?!€£\&@()}

Esta tipografía, fue elegida para los Panamericanos debido a que con sus líneas transmite modernidad, seguridad y alegría. La finalidad de esta decisión es la de trasladar los atributos positivos que evocan los Juegos Panamericanos a la Villa de Atletas. Además, por su carácter acentúan dinamismo, energía y espíritu deportivo, la legibilidad y versatilidad que las piezas gráficas necesitarán.

\subsection{Colores}

Decidimos mantener los colores elegidos para los Juegos Panamericanos y Parapanamericanos 2019, al ser la Villa un legado, este debe preservarse. Como sabemos, la "Flor de Amancaes" es la principal inspiración en forma y color que se usó para el logotipo de los juegos deportivos, es así que los colores viene de la naturaleza, pues representan el mar, la naturaleza, la vida, entre otros que podemos ver en la figura 22.

Sin embargo, el significado de los colores sería ligeramente modificado con fines comunicacionales. 

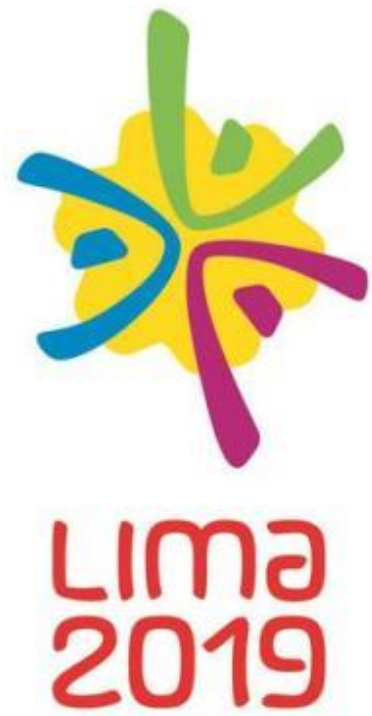

PANAMERICANOS

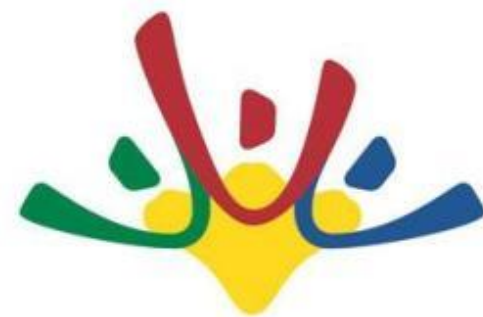

LIMO

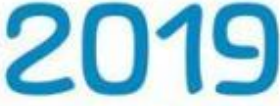

PARAPANAMERICANOS

Figura 22: Logos Panamericanos y Parapanamericanos

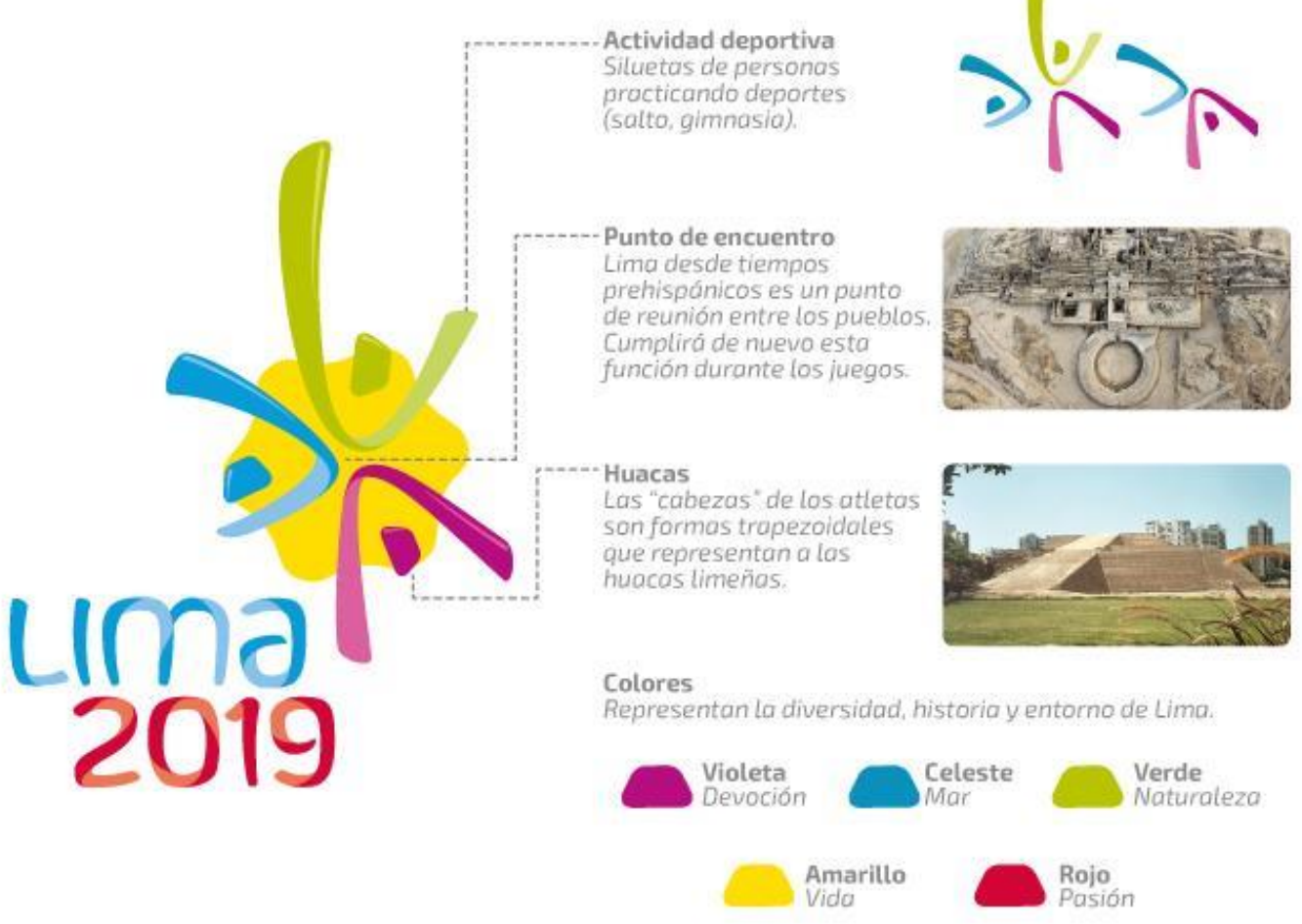

Figura 23: Explicación logo Panamericanos 

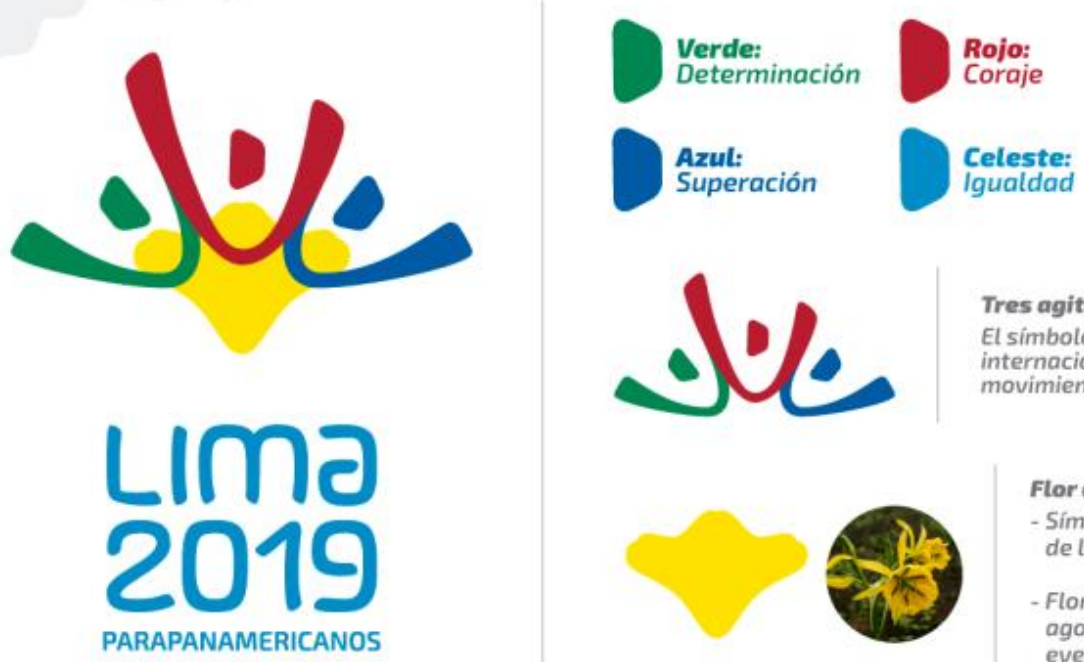

Tres agitos:

El simbolo que identifica

internacionalmente el

movimiento paralímpico.

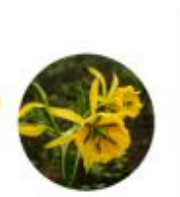

Flor de amancaes:

- Símbolo de viday

de la ciudad de Lima.

- Florece entre julio y

\section{LIIma

Figura 24: Explicación logo Parapanamericanos

A continuación presentamos los colores y sus significados vinculados a la psicología del color y a la carga de la naturaleza vinculada a conceptos de superación, coraje, ecología e igualdad de oportunidades.

\begin{tabular}{|l|l|l|l|}
\hline Color & $\begin{array}{l}\text { Significado } \\
\text { Panamericanos }\end{array}$ & $\begin{array}{l}\text { Significado } \\
\text { Parapanamericanos }\end{array}$ & $\begin{array}{l}\text { Significado Villa } \\
\text { Atletas }\end{array}$ \\
\hline Celeste & Mar & Igualdad & $\begin{array}{l}\text { Igualdad de } \\
\text { oportunidades }\end{array}$ \\
\hline Verde & Naturaleza & Determinación & $\begin{array}{l}\text { Cuidado del } \\
\text { ambiente }\end{array}$ \\
\hline Rojo & Pasión & Coraje & $\begin{array}{l}\text { Coraje por salir } \\
\text { adelante }\end{array}$ \\
\hline Azul & - & Superación & Superación \\
\hline
\end{tabular}


Tabla 3: Cuadro de elaboración propia sobre los colores y su significado.

\subsection{Simbolismo y formas}

Respecto al isotipo planteado para la Villa Panamericana, se ha construido bajo la figura de una estrella de siete puntas "representando los 7 edificios que constituyen". Además, el siete es un número muy importante en la cultura andina ya que representa prosperidad, buena suerte y buenos augurios. Al centro de esta estrella hay un círculo que evoca el detalle que tienen los isotipos de los Juegos Panamericanos y Parapanamericanos. Con este círculo queremos representar el centro de las familias que es la unión y la convivencia sana.

5.6 Imágenes que evoquen la marca

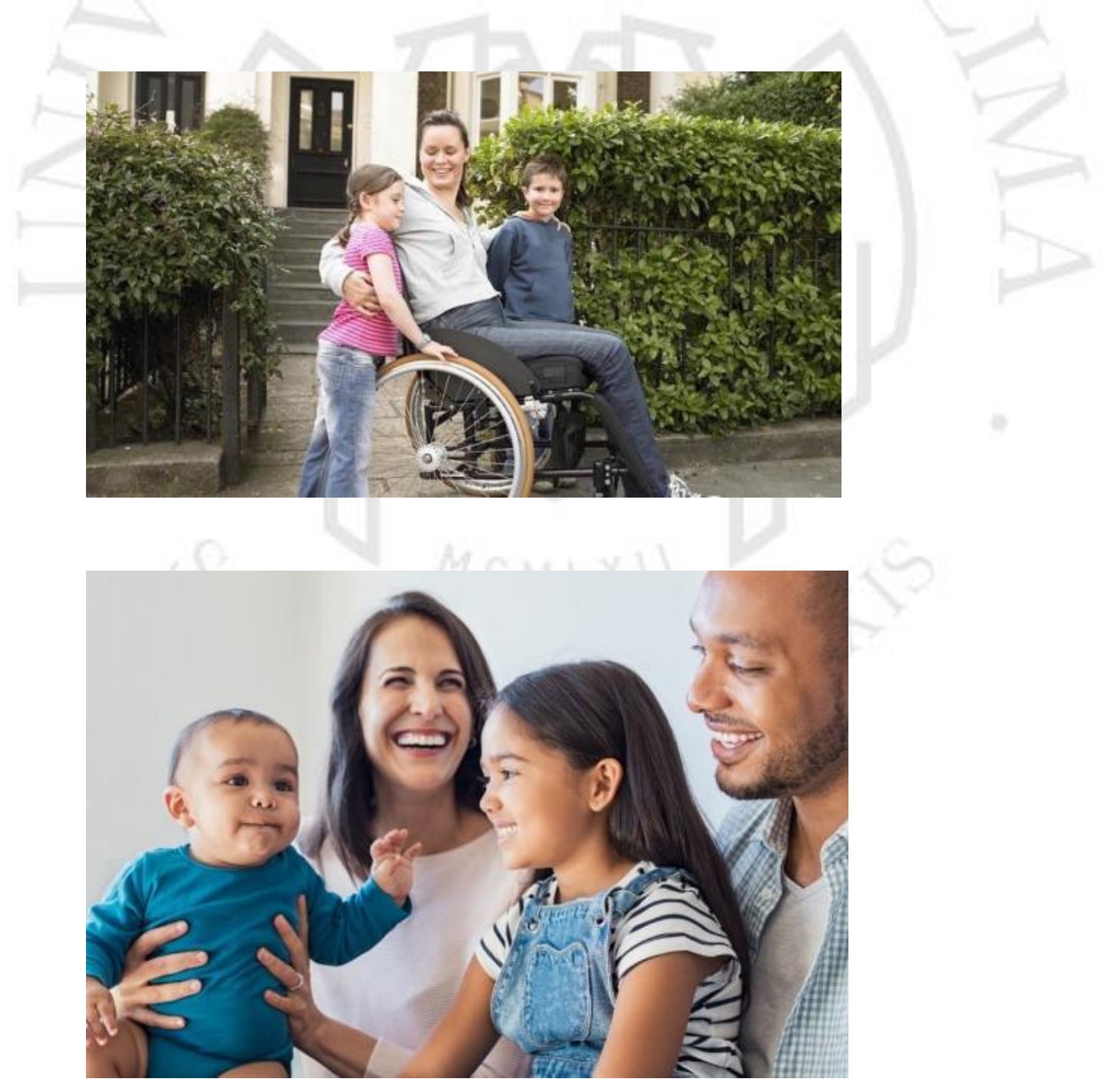



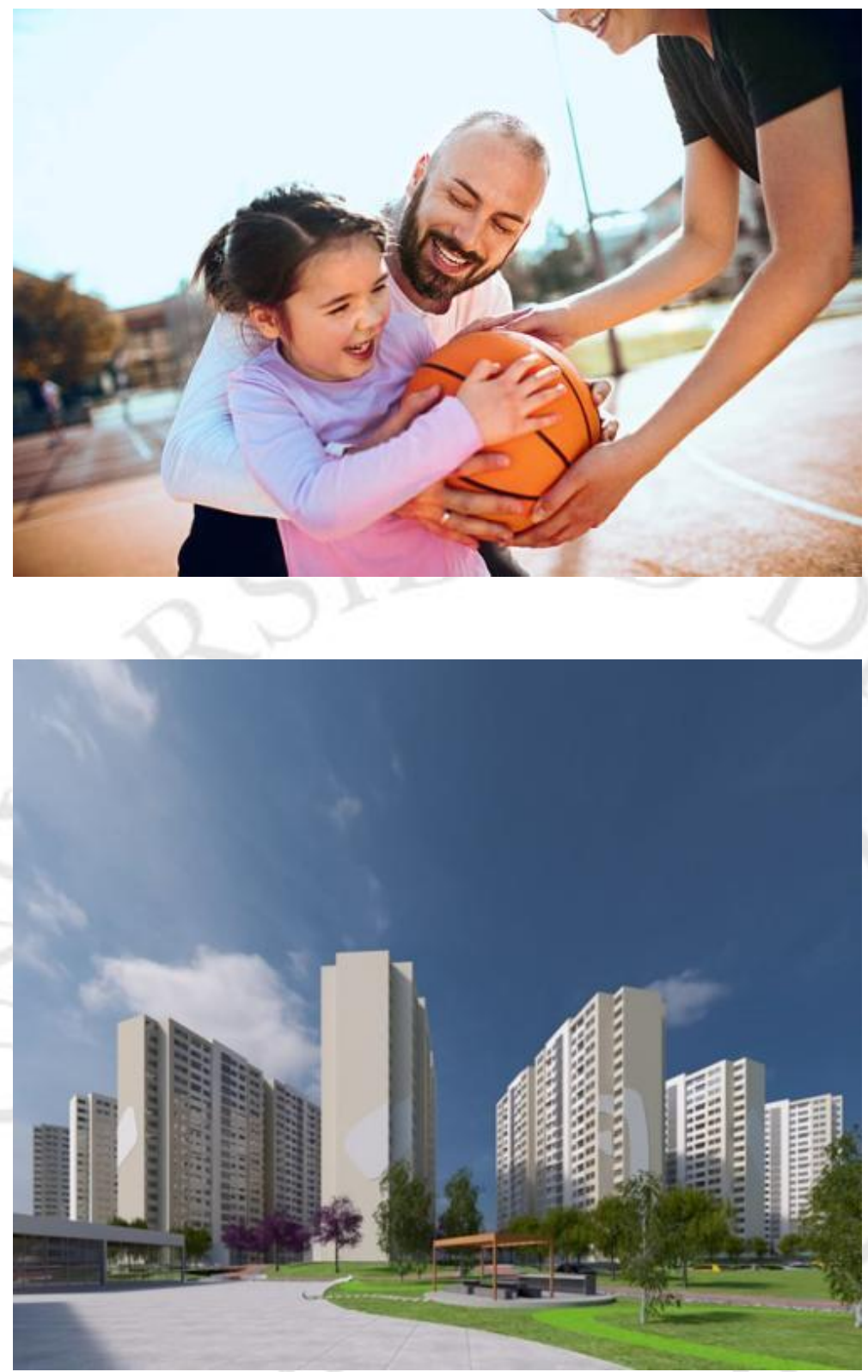

5.7 MANUAL DE MARCA

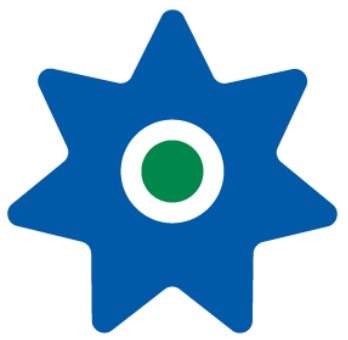

Arte final horizontal 


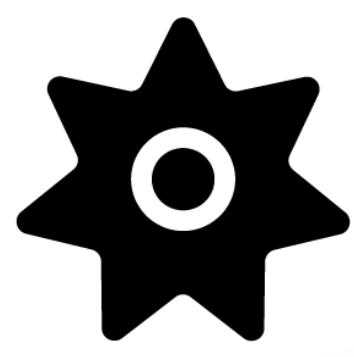

\section{VILLA}

PANAMERICANA

Arte en positivo

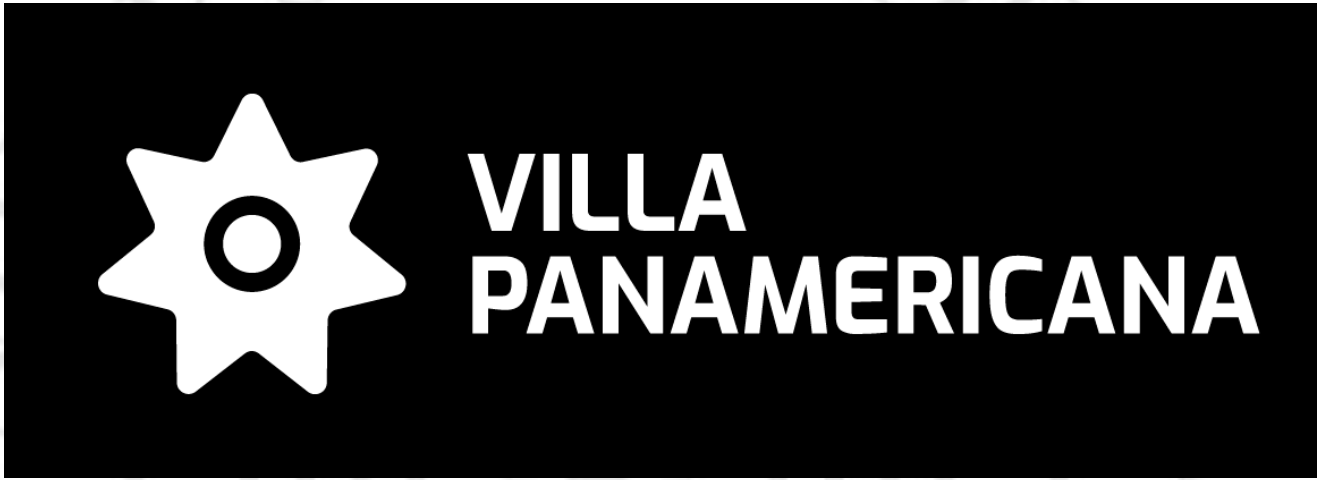

Arte en negativo

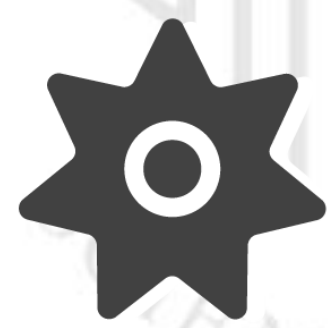

VILLA

PANAMERICANA

Arte en escala de grises 


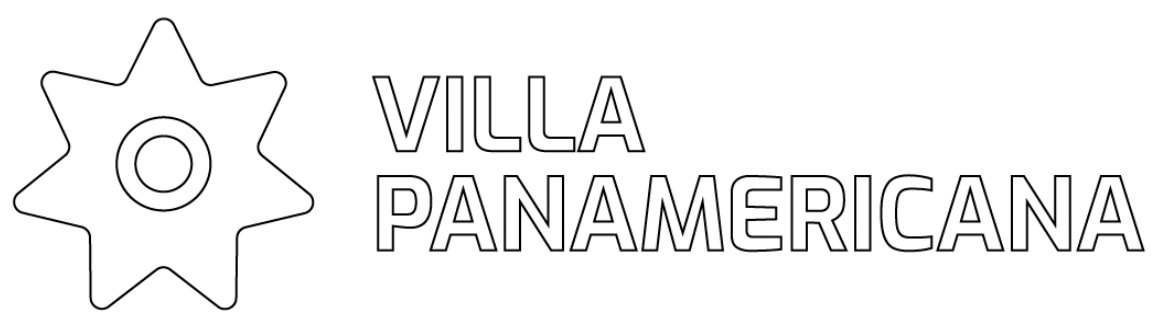

Arte delineado
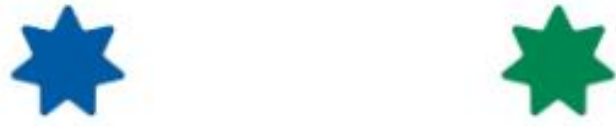

C: 98 H: 206 R: 0

M: 69 S: 100 G: 90

$\begin{array}{lll}\text { Y: } 8 & \text { B: } 64 & \text { B: } 164\end{array}$

K: 0 \#005aa4

C: 98 H: 155 R: 0

M: 22 S: 100 G: 135

$\begin{array}{llll}\text { Y: } 93 & \text { B: } 52 & \text { B: } 81\end{array}$

K: 0

\#008751
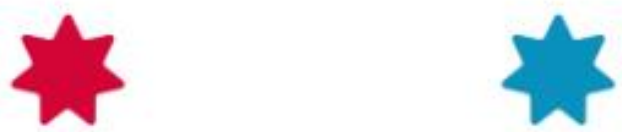

C: 0 H: 344 R: 210

$\begin{array}{lll}\text { M: } 98 \text { S: } 97 \quad \text { G: } 5 & \end{array}$

$\begin{array}{llll}\text { Y: } 77 & \text { B: } 82 & \text { B: } 54\end{array}$

K: 0

\#d20536

C: 95 H: 194 R: 10

$\begin{array}{lll}\text { Y: } 23 & \text { B: } 73 & \text { B: } 188\end{array}$

K: $0 \quad \# 0 \mathrm{a} 90 \mathrm{bc}$

\section{Paleta de colores}




\section{LA CAMPAÑA}

\subsection{Objetivos}

\subsubsection{De marketing}

- Lograr la venta del $100 \%$ de los departamentos. La venta se iniciará en enero del 2020 y se busca concluir máximo el segundo trimestre del mismo año.

\subsubsection{De comunicación}

1. Dar a conocer el proyecto y sus características.

2. Motivar al target a adquirir uno de los departamentos.

3. Comunicar al target acerca de las modalidades de financiamiento a través del programa Mivivienda.

\subsection{Estrategia creativa}

\subsubsection{Concepto}

En los últimos 15 años el Perú ha tenido un crecimiento económico destacado a nivel mundial. Hemos generado cientos de millones de dólares en inversión. A pesar de esto, la riqueza de nuestro país no ha beneficiado de igual manera a todos los peruanos. Día a día hay personas que se sacrifican por el futuro de su familia, que cambian de ciudad para buscar un mejor futuro. Todas esas personas comparten un sueño en común, el cual es la felicidad, saber que tenemos un lugar en el cual todo va a estar bien. Para ser felices tenemos que ser capaces de darles un ambiente seguro a los nuestros donde no les falte lo que alguna vez nos faltó.

Siguiendo esta línea, nos parece importante señalar un fuente de donde podemos comprobar lo anteriormente expuesto a través de un estudio como es "La Felicidad de los Peruanos Kusikuy" (2019), realizado por Arellano, Ernst \& 
Young, Perú 2021, el Fondo Editorial USIL y Arellano Consultoría. Es allí donde "podemos encontrar que los aspectos con mayor satisfacción son los relacionados con la inteligencia emocional (aspectos intrapersonales e interpersonales) y las condiciones de vida básicas para el progreso (educación, vivienda y salud)" (Arellano, 2019). En concreto, aquí queremos referirnos a los descubrimientos en cuanto a la satisfacción de cumplir metas que le generan felicidad a los peruanos: Tener una vivienda/cuarto propio tiene un $93 \%$ de satisfacción dentro de la muestra, así mismo, "vivir en un lugar limpio y bonito", cuenta con un $90 \%$ y "vivir en un lugar seguro" un $76 \%$ (Arellano, 2019)

En el marco de este contexto e insight plantemos el siguiente concepto:

\section{La felicidad viene de casa}

\subsubsection{Idea racional}

"Comprar un vivienda representa un inversión en el futuro de nuestra familia."

La felicidad también se puede comunicar a través de un ángulo racional. La adquisición de una vivienda con los bonos mencionados anteriormente es una oportunidad que nuestro target valora, pues le permite ahorrarse una suma importante de dinero en su compra. A mediano plazo, están ganando un lugar que les permite ahorrar en consumo de servicios básicos como son el agua y la luz. Finalmente, a largo plazo vemos el beneficio más poderoso: el precio de los inmuebles aumenta su valor en el tiempo.

\subsubsection{Idea emocional}

"La felicidad es estar en el hogar."

La felicidad en el hogar viene de las vivencias y los momentos especiales que pasamos en nuestras casas. Es en este hogar donde los hijos crecen, desde los primeros pasos y palabras hasta que terminan sus estudios. Queremos trasladar el sentimiento de pertenencia hacia la Villa Panamericana, que sea el lugar donde las experiencias de estas familias 
se creen, donde pasen los años maravillosos de su vida. Queremos que vean esta oportunidad de compra como una ventana a conseguir los atributos que generan felicidad en los peruanos basándonos en el estudio "La Felicidad de los Peruanos Kusikuy" (2019), citados párrafos atrás.

\subsection{Estrategia de comunicación de la campaña}

Hemos decidido tener dos fases para cumplir con los objetivos y tener una comunicación más efectiva con el target. A continuación, planteamos las acciones en los diferentes medios en estas fases:

\section{Fase de pre lanzamiento ( 2 meses)}

En esta fase queremos despertar el deseo de las familias que han pensado mejorar su calidad de vida comprando una vivienda propia, esta comunicación responde al objetivo de dar a conocer el proyecto (awareness). Considerado la data sobre la consulta de medios digitales que realizan los compradores de inmuebles y tomando en consideración el presupuesto con el que contamos, esta etapa será digital y radio. El periodo pensado para la ejecución es desde noviembre hasta diciembre 2019.

DIGITAL

- 8 posts de Facebook

- 8 posts de Instagram

- 40 stories

- 16 posts de Twitter

\section{Fase de lanzamiento (3 meses)}

A continuación, pasaremos a plantear una fase en la que cumpliremos con el objetivo de ventas y comunicación efectiva de la oportunidad de venta. Mediante distintas tácticas llevaremos a los consumidores a interactuar y tomar acción. 
ATL

- Televisión: 1 spots

- Radio: 1 spots

- Medios Impresos: 2 páginas

- $\mathrm{OOH}: 8$ paneles

BTL

- Festival Inmobiliario Panamericano.

- Marketing directo: tapete y llaves. Carta dirigida a modo de título de propiedad.

\section{DIGITAL}

Contenido inbound + leads:

- 24 posts de facebook

- 24 posts de instagram

- 3 dark posts de facebook

- 50 posts de twitter

- 6 artículos de blog

En la siguiente sección de nuestra propuesta, se explicará en qué consistirán las piezas de cada fase planteadas. Algunas, según su naturaleza, serán retratadas a modo de boceto para ejemplificar y tener mayor claridad.

\subsection{Estrategia ATL}

\subsubsection{Pre lanzamiento}

- Radio

A través del sonido queremos expresar la felicidad que comenzar una nueva etapa en la vida al adquirir una vivienda propia, ese es el sentimiento que motivará al target. Además, vamos a comunicar 
el lanzamiento de la página web donde podrán encontrar información sobre el proyecto

Guion de radio:

Locutor con efecto de voz de radio: $3 \ldots 2 \ldots 1 \ldots$ ¡Feliz Navidad!

Voz de Mujer: Bueno familia tengo un regalo muy especial en esta caja

Voz de hombre: Diles las noticias

Se oyen que se abre el papel de regalo y unas llaves siendo agitadas

Voz de mujer: ¡Nos mudamos a la Villa Panamericana!

Familia: voces múltiples: ¡felicidades!

Voz de locutor: Descubre la felicidad en la Villa Panamericana, departamentos a la venta desde el primero de enero. Para más información ingresa a villapanamericana.pe

\subsubsection{Lanzamiento}

\section{- Televisión}

A través un comercial en señal abierta queremos comunicar a nuestro público que la Villa Panamericana es un excelente lugar para que se desarrollen como personas, sobre todo para sus hijos. Responde a los objetivos de dar a conocer el proyecto y motivar al target a adquirir uno de los departamentos.

Guion para televisión: 
Una mujer abre las cortinas de un cuarto, lo que se revela en el fondo son los edificios de la Villa Panamericana, en el plano parecen la frase: “¿Recuerdas la felicidad del hogar?”.

Vemos a Gladys Tejeda en la fachada de su primera casa en la sierra, ella está mirando directamente a la cámara, tiene su ropa deportiva y su medalla de oro, su actitud es de orgullo y superación.

Luego vemos a Alexandra Grande tomando desayuno en su casa junto a su familia.

Vemos como un grupo de niños juega fútbol en la losa deportiva de la Villa Panamericana, el punto de vista se abre para ver más desde el complejo. Después vemos como uno de esos niños está corriendo en la pista de footing de la Villa y a medida que corre va creciendo, los edificios están en el fondo.

Luego vemos un grupo de atletas y para-atletas en el medio de la villa, están con sus medallas felices de sus logros.

En la pantalla podemos leer: El lugar donde vives y el lugar donde viven tus hijos crecen define de muchas maneras cómo van a ser en el futuro. Descubre la felicidad en la Villa Panamericana.

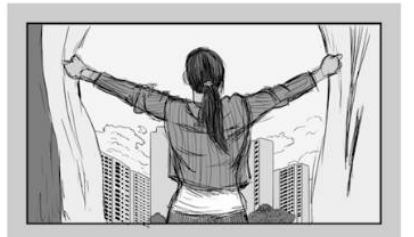

$>$

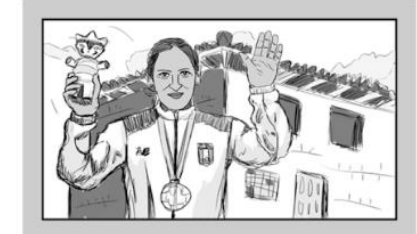

$>$
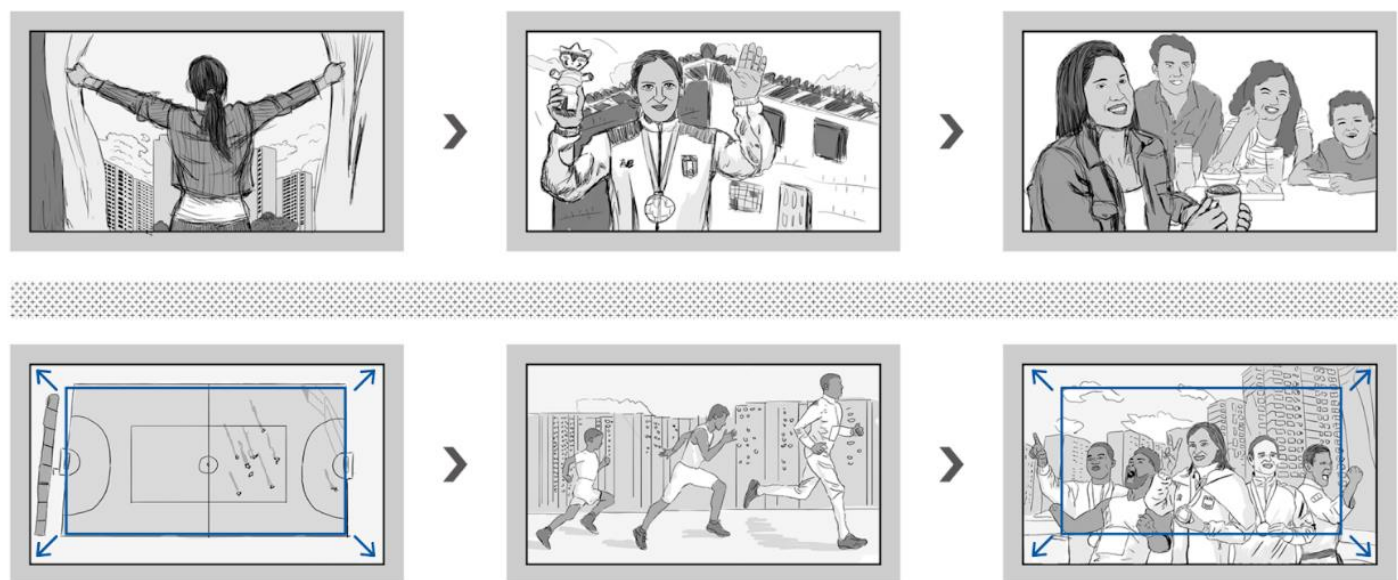

Storyboard 


\section{- Radio}

A través del sonido queremos expresar alguna de las cosas que nos hacen felices, siempre vinculándolo a la aspiración que tiene el target por lograr adquirir la vivienda propia.

Guion de radio 1:

Locutora: ¿Alguna vez te has preguntado cómo suena la felicidad?

Hombre 1: Estas son las llaves de su nuevo departamento.

Sonido de llaves.

Niños jugando.

Hijo niño: Por fin llegaste papá...

Hija Adolescente: Mamá, el próximo mes es mi graduación.

Locutor: Pero también suena así.

Sonido de disparo de atletismo, sonido de nadadores en el agua, sonido de las pesas cayendo al suelo, sonido de muchas personas corriendo sobre el pavimento, sonido de las olas del mar.

Locutor: La felicidad viene de casa, vive en la Villa Panamericana

Guion de radio 2:

Sonido de disparo de atletismo, sonido de nadadores en el agua, sonido de las pesas cayendo al suelo, sonido de muchas personas corriendo sobre el pavimento, gritos de aliento y aplausos. 
Locutor: El lugar donde vives y el lugar donde viven tus hijos crecen define de muchas maneras cómo van a ser en el futuro.

Adquiere tu vivienda propia en la Villa Panamericana, departamentos desde 186,000 soles, aplican descuentos del Nuevo crédito Mivivienda, bono verde y bono del buen pagador. Más información en villapanamericana.pe.

\section{- $\mathrm{OOH}$}

En cuanto a comunicación gráfica, plantemos comunicar de manera directa el precio, los beneficios de financiamiento, bonos y demás ventajas. Así mismo, nos mantenemos fieles a nuestra idea emocional. Al mismo tiempo, que nuestro canal ventas digital se potencia con las menciones de la web y las redes sociales.

La ubicación de estas piezas es donde hay mayor densidad poblacional del target (Lima sur, Lima norte y Lima centro). Cabe resaltar que tendremos espacios dentro de las estaciones de la línea 1 del metro de lima.

\section{Descubre la felicidad}

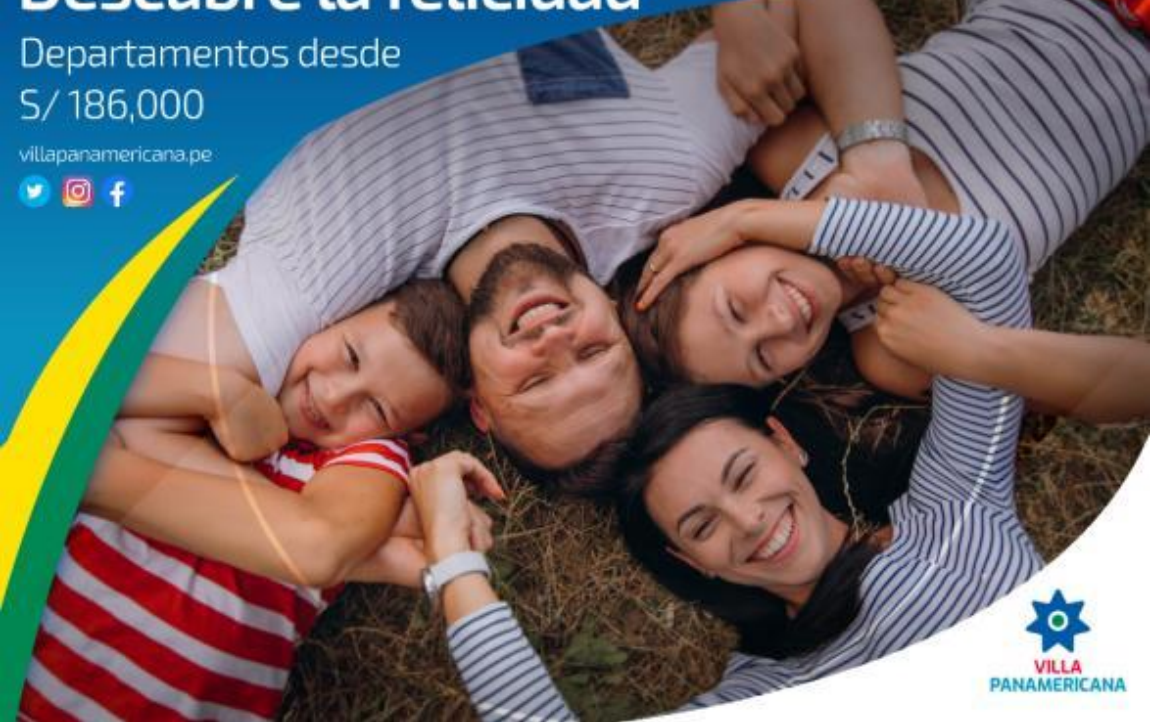

Panel $n^{\circ} 1$ 


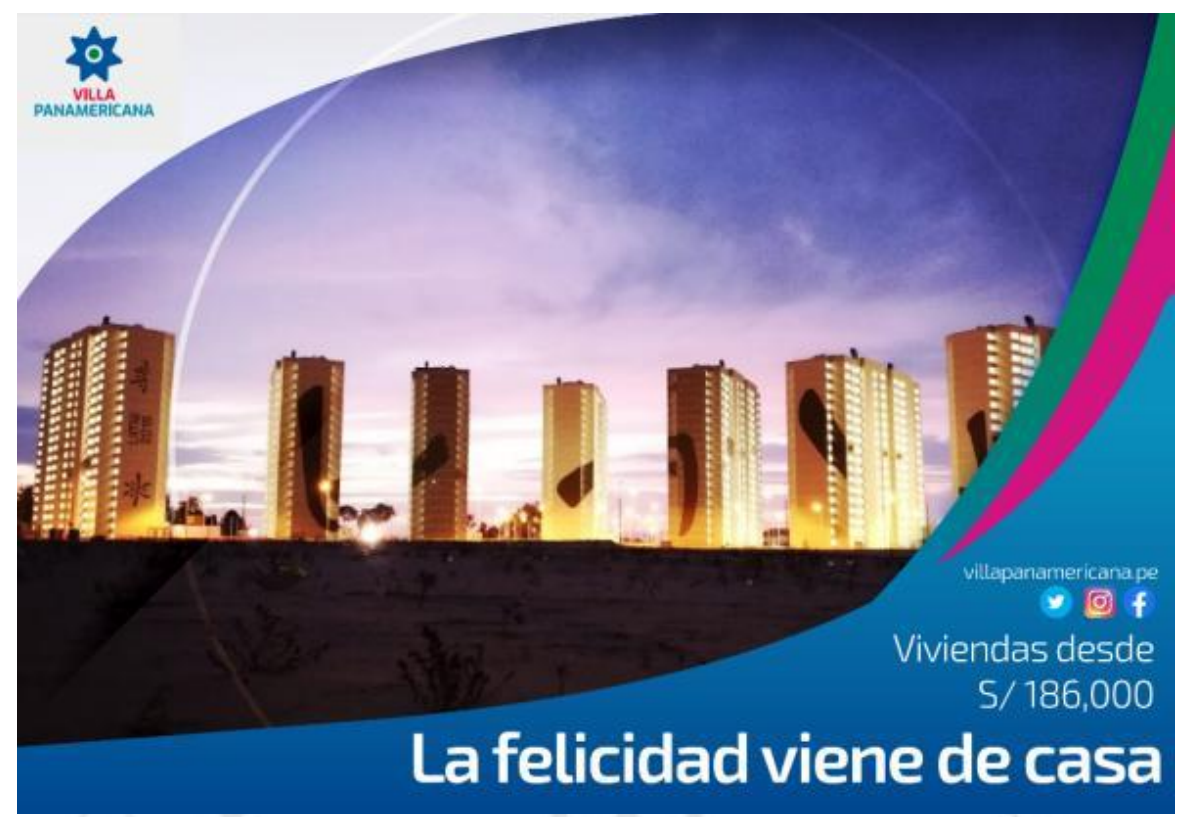

Panel $n^{\circ} 2$

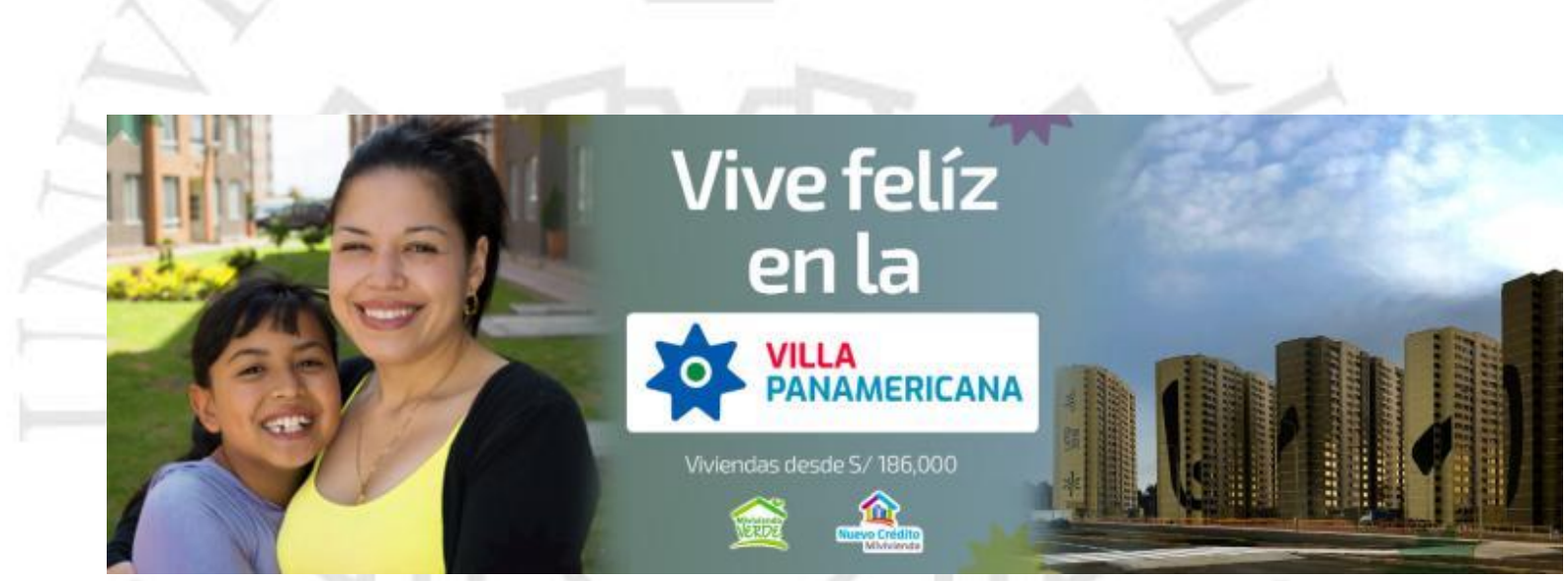

Panel para las estaciones de la línea 1

\subsection{Estrategia Digital}

\section{Content Marketing}

Establecimos los siguientes ejes de contenido sobre los cuales pueden ir los intereses de nuestro público objetivo cruzados con los objetivos de la marca.

\section{Eje temático 1: "Felicidad es..."}

En esta categoría se abordarán los insights que despierten la sensación de bienestar máxima de nuestro target desde cosas simples hasta deseos más profundos.

Eje temático 2: "Familia y hogar" 
Incluye temas de familia, desarrollo emocional, relaciones interpersonales, decoración del hogar, organización de espacios, etc.

\section{Eje temático 3: "Vida saludable"}

Incluye temas de ecología, medio ambiente, alimentación saludable y deporte.

Estos ejes temáticos se verán materializados en diferentes posts para las siguientes redes sociales: Facebook, Twitter e Instagram. Adicionalmente se contará con una página web y un blog.

Con un propósito gráfico y explícitamente referencial, vale recalcar que las imágenes utilizadas para graficar a continuación los ejemplos de contenido no son de nuestra propiedad, sino que se trata de imágenes de libre uso.

\subsubsection{Facebook}

\section{Prelanzamiento}

Abordaremos el tema de la felicidad y el confort del hogar. No hay lugar como el hogar.

\section{EJEMPLO POST 1}

Copy: Hay cosas que simplemente nos hacen felices. Sacarse los zapatos luego de una larga jornada de trabajo es una de ellas. ¿Qué otras cosas te gustan de volver a casa?

\#FelicidadEs 
Felicidad es... llegar a casa y sacarte los zapatos

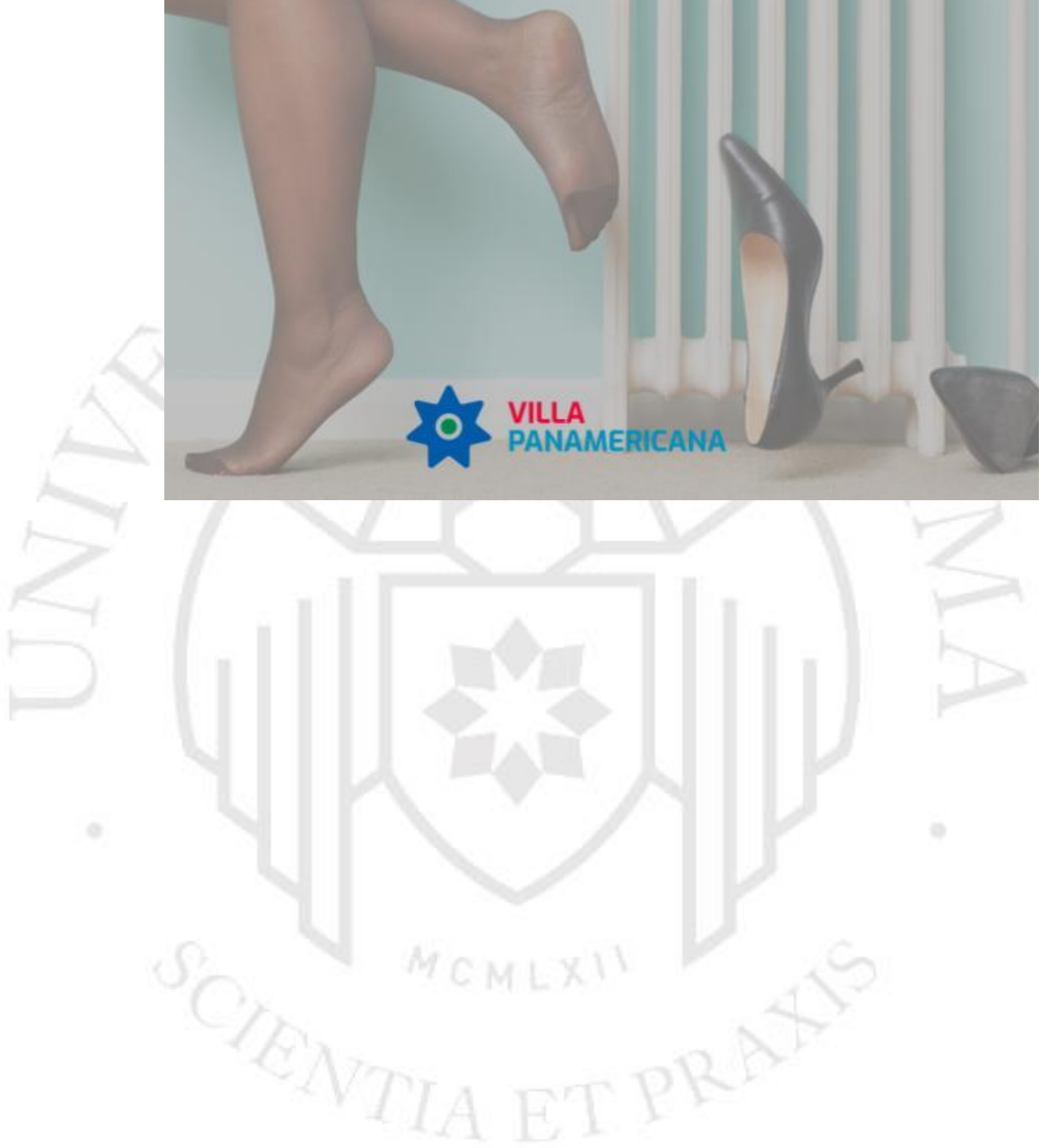




\section{EJEMPLO POST 2}

\#FelicidadEs que haya un plato de tu comida favorita esperándote. ¿A ti qué plato te llena de felicidad cuando llegas a casa?

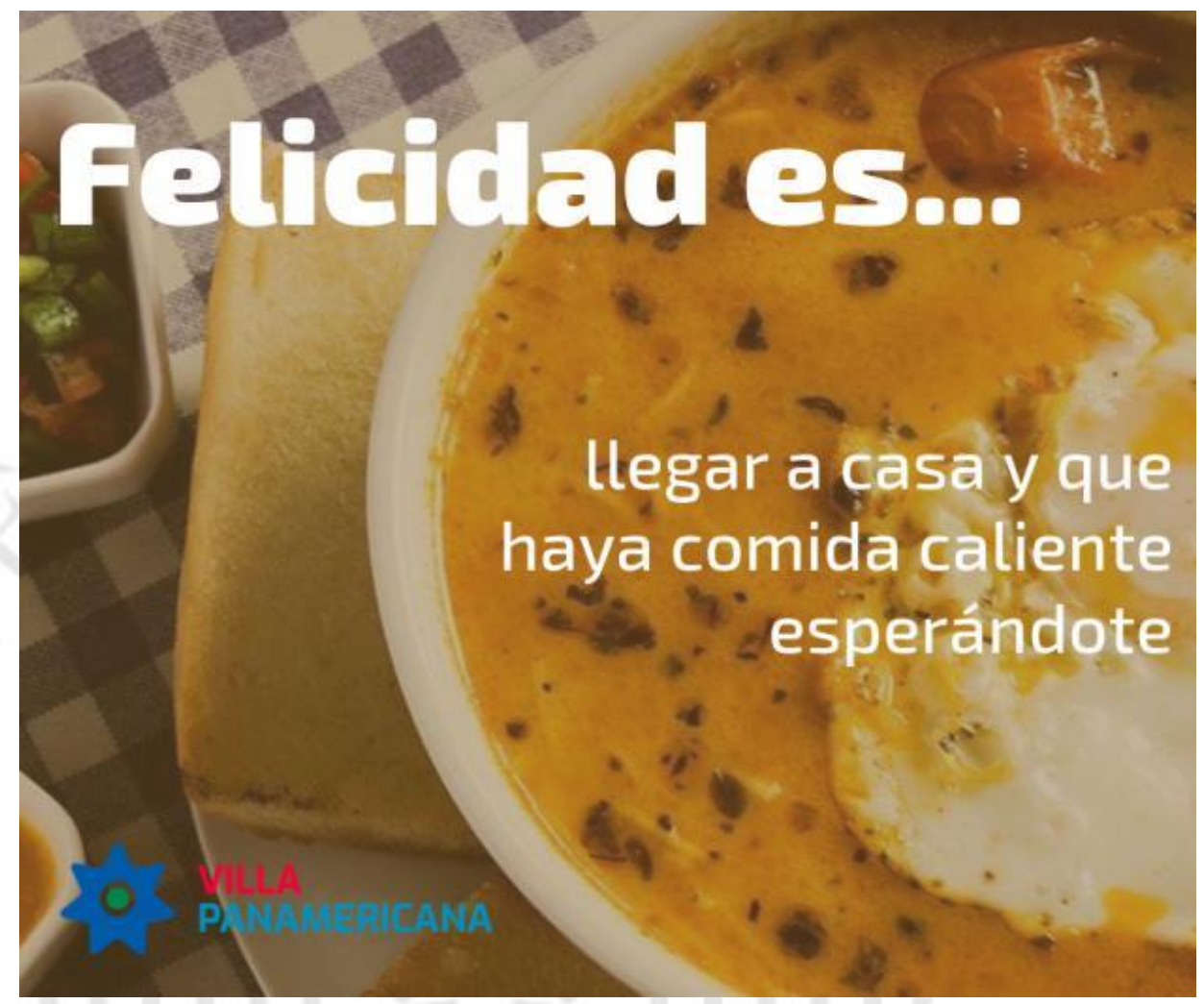

\section{Lanzamiento}

Se desarrollarán piezas de engagement ya más relacionadas al ámbito de la familia, la casa, las metas y el futuro.

\section{EJEMPLO POST 1}

Felicidad es pasar tiempo con los que más me importan 


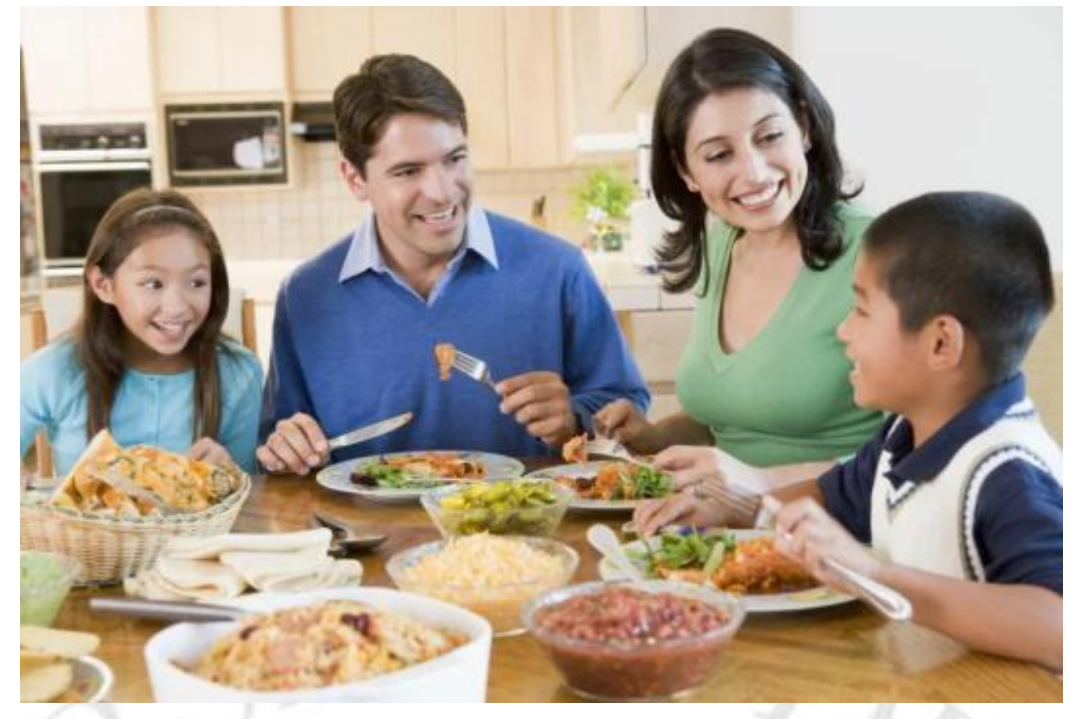

\section{EJEMPLO POST 2}

Felicidad es cumplir mis metas

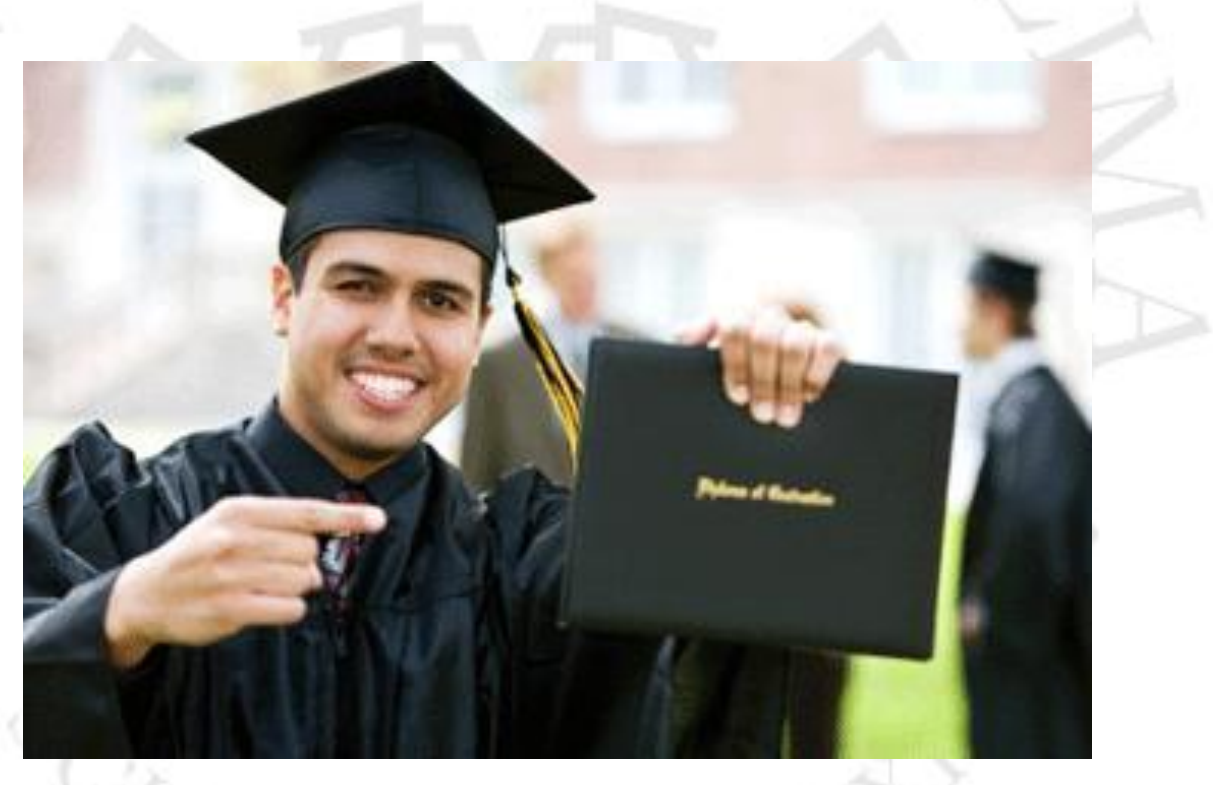

\section{EJEMPLO POST 3: GIF}

Copy: ¿Sabías que todos los departamentos de la Villa Panamericana cuentan con 3 habitaciones? Pero un departamento cobra vida cuando existe una familia que lo decore.

Familia Galván 


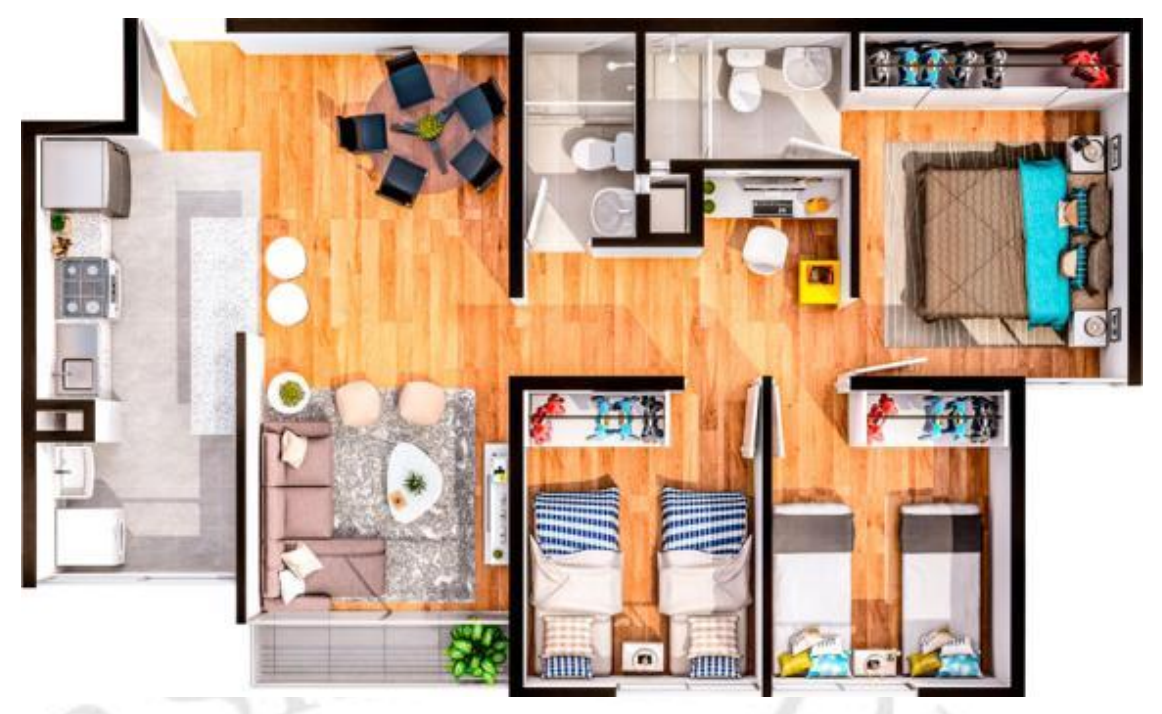


Familia Rivera

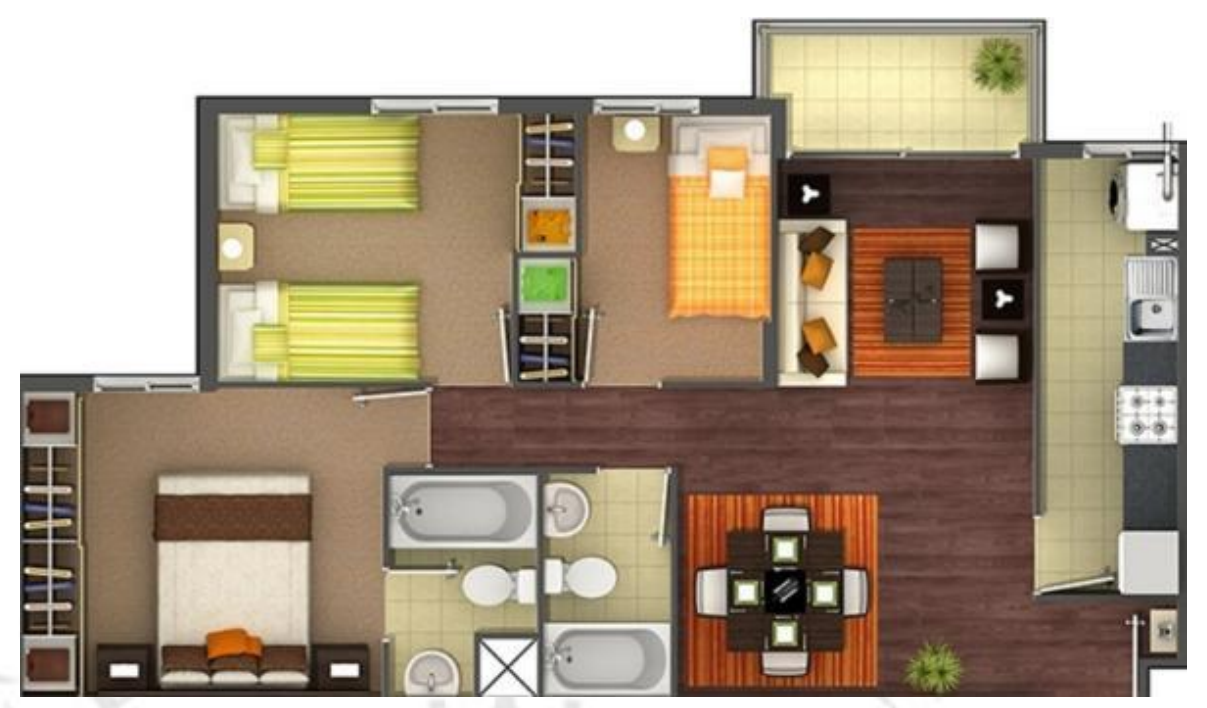

Familia Quispe

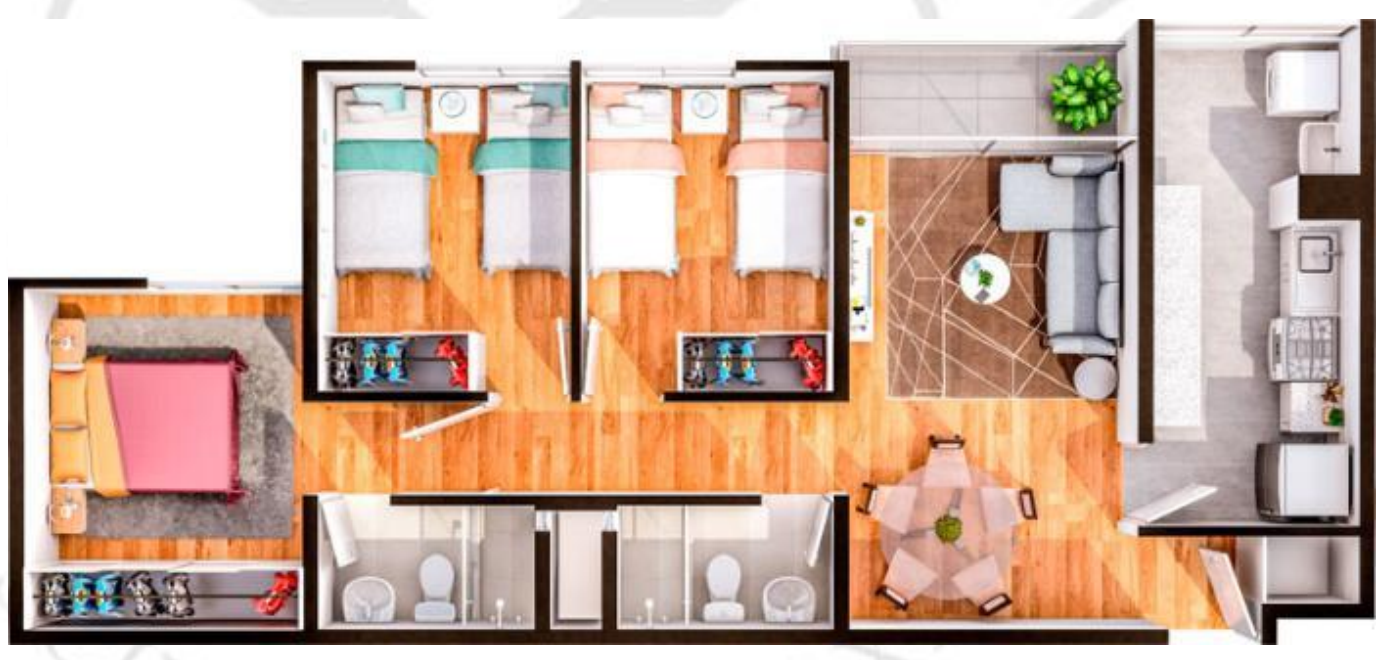

\subsubsection{Instagram}

\section{Prelanzamiento}

La idea es compartir fotografías y frases relacionadas al esfuerzo, al trabajo y a las metas personales.

\section{EJEMPLO POST 1:}


Copy: Es normal querer abandonarlo todo. La vida no es fácil. Lo importante es seguir adelante y no detenerse, a menos que sea para recargar baterías antes de continuar. \#Motivation

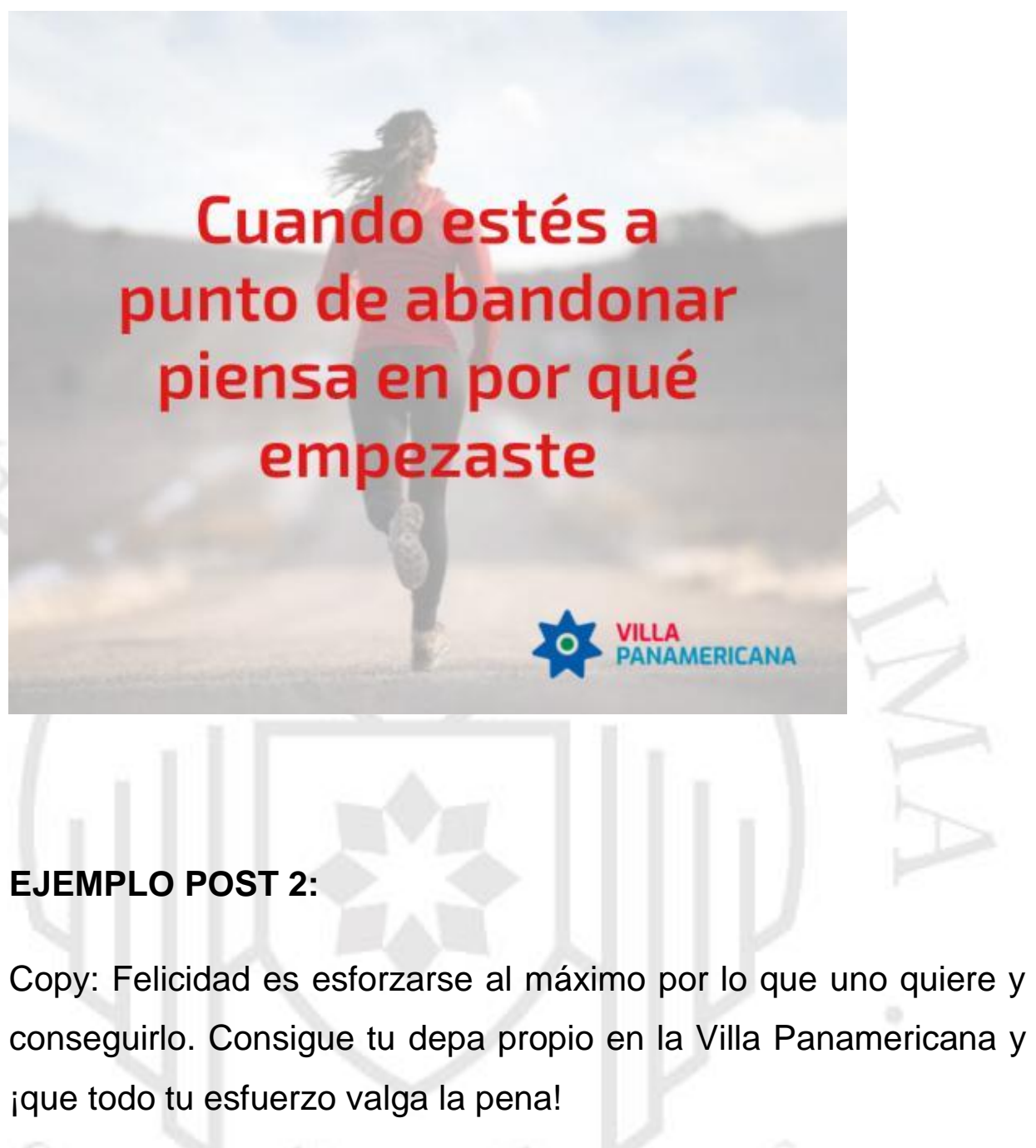




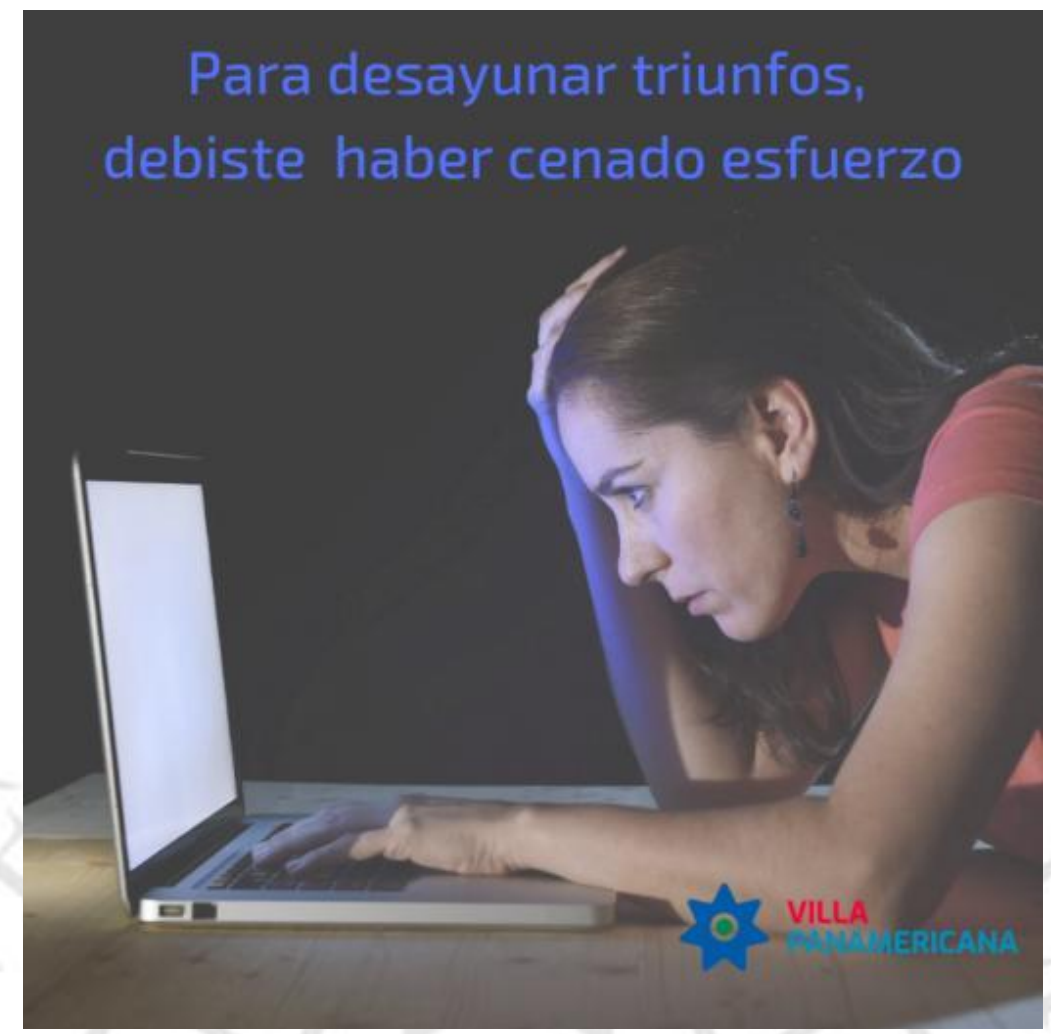

STORIES: Serán de los obreros realizando los trabajos de construcción, mantenimiento de áreas comunes y distintas obras. la idea es seguir el dicho de Alfred Hitchcock "show don't tell".

\section{EJEMPLO STORIE 1:}

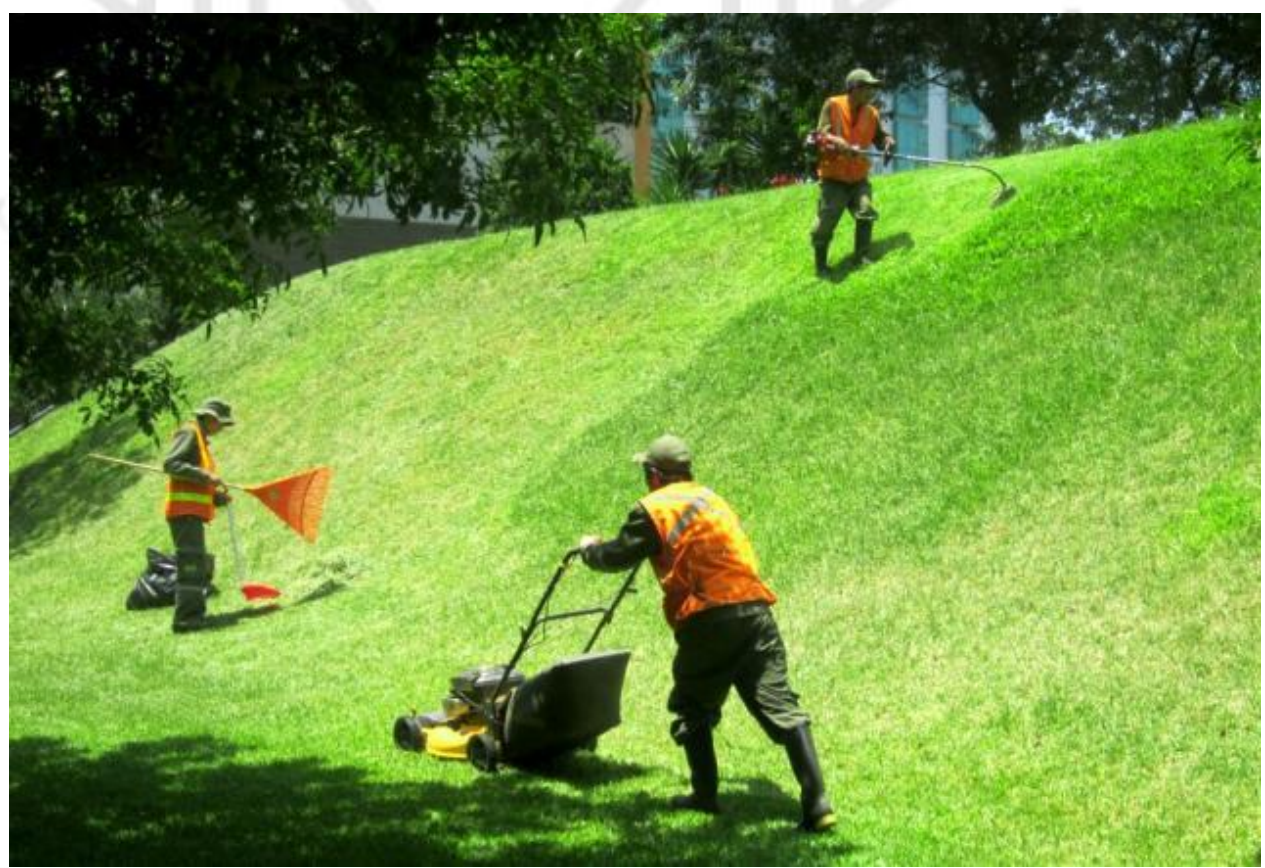




\section{EJEMPLO STORIE 2:}

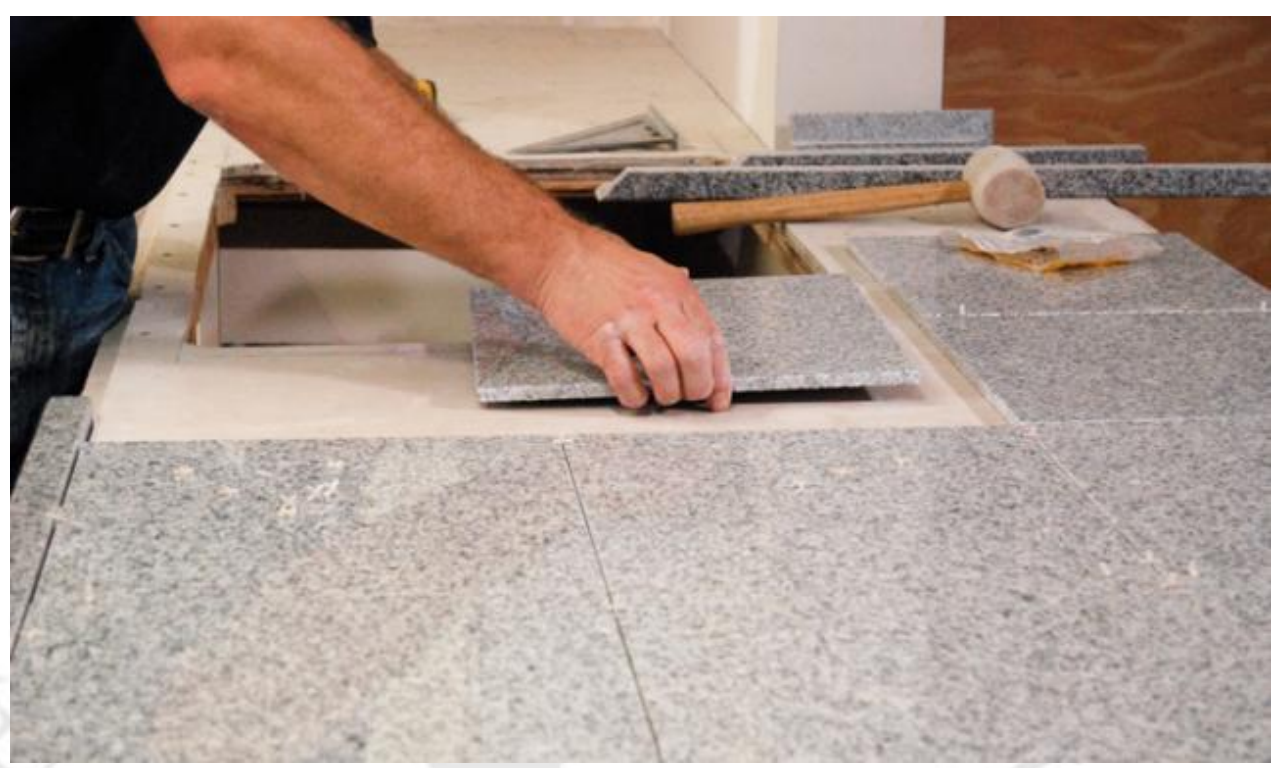

\section{Lanzamiento}

Compartiremos fotografías en alta calidad del complejo y combinarlas con imágenes y frases relacionadas al hogar y la familia. Sin embargo, principalmente se realizarán stories de los trabajadores remodelando y cuidando el complejo. Mostrar los lenguajes brailles. Paso a paso iremos comunicando todos los beneficios mediante historias que luego serán destacadas. Otras opciones audiovisuales pueden incluir videos del recorrido a través de los departamentos de la Villa Panamericana. Además, usaremos el concepto de "Felicidad es" para continuar apelando a esa emoción única que encontramos en el hogar.

EJEMPLO POST 1: ¡Solo faltan 20 días para la venta oficial de los departamentos de la Villa Panamericana! 


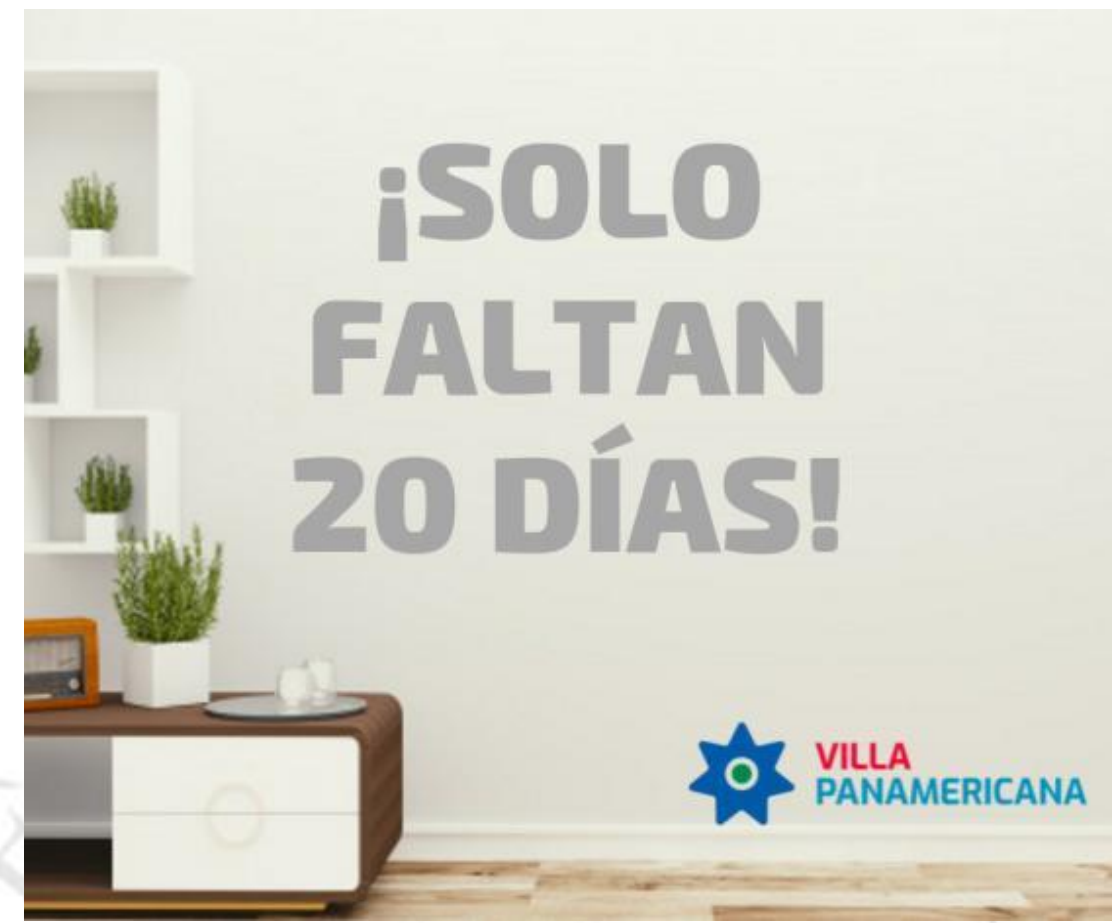

\section{EJEMPLO POST 2:}

Hay sensaciones incomparables en esta vida. Cuándo estás en casa, ¿qué sensaciones te hacen feliz?

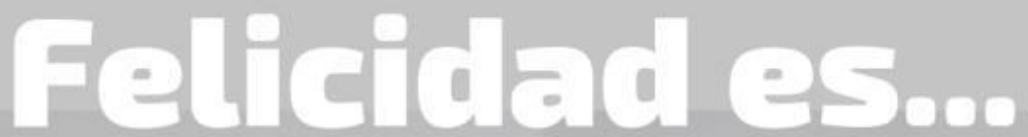

\section{meterte en tu cama con sábanas limpias}

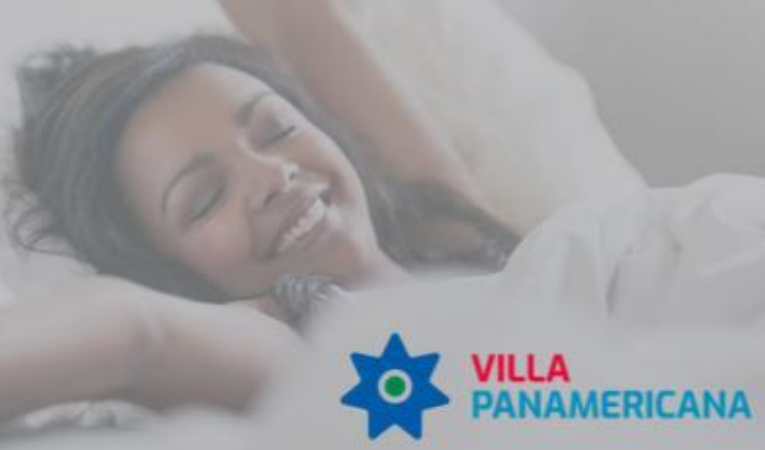




\section{EJEMPLO POST 3:}

Felicidad es tener un lugar al que puedo llamar hogar

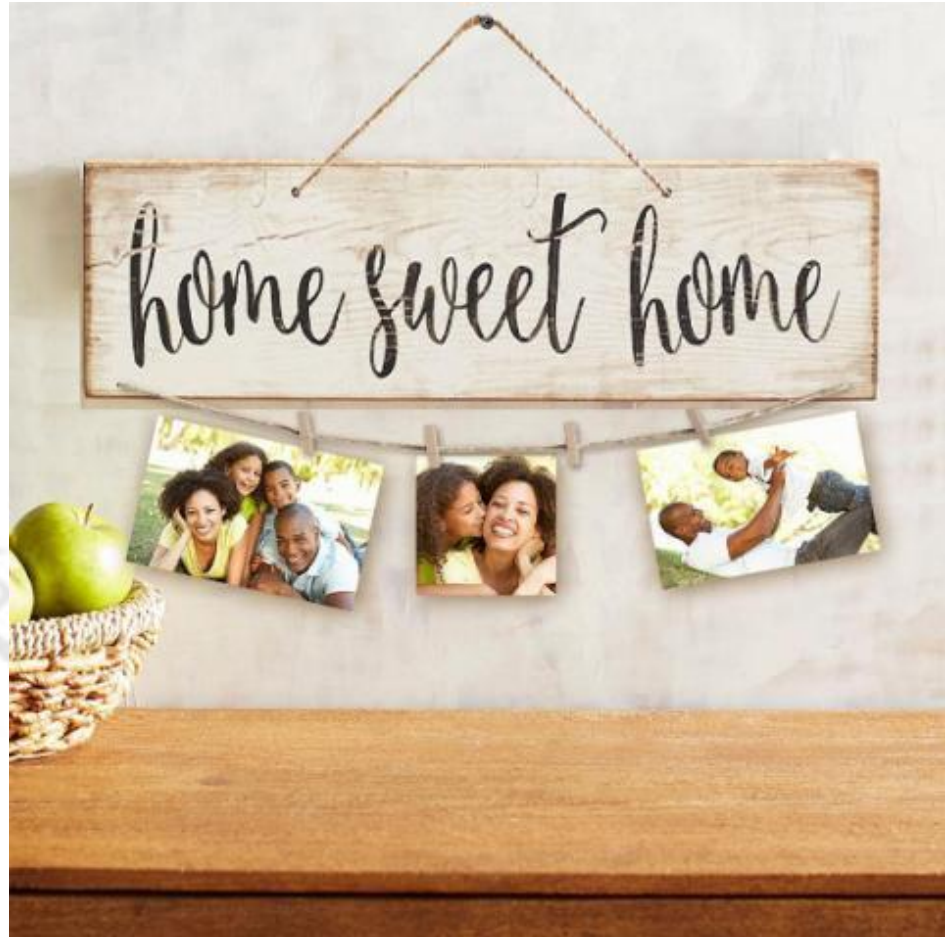

\section{EJEMPLO POST 4:}

Felicidad es disfrutar de la naturaleza sin salir de casa. Vive como los campeones, vive en la Villa Panamericana.

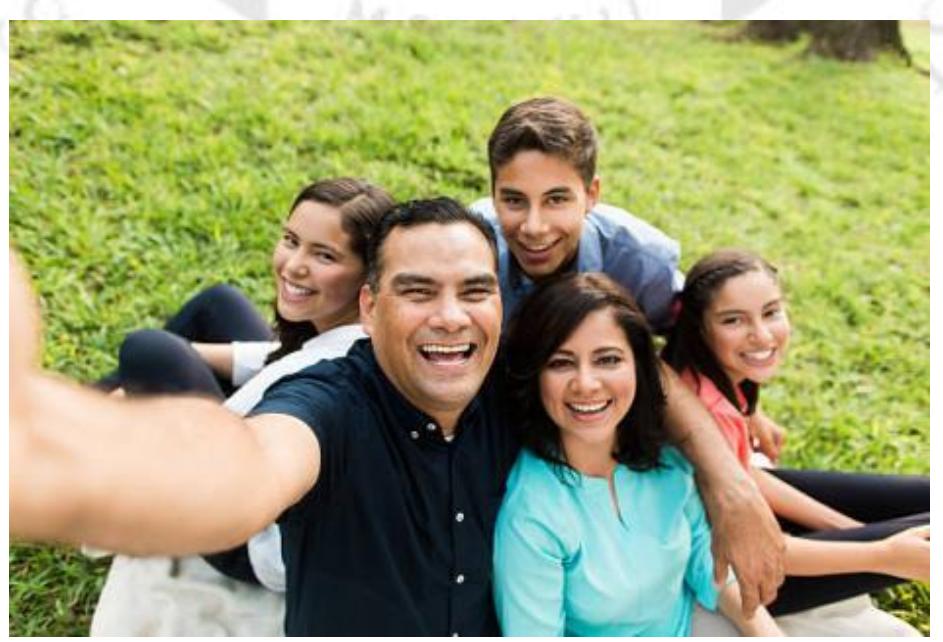

EJEMPLO POST 4: GIF 
Una de las partes más divertidas de una casa nueva es decorarla. ¡En la Villa Panamericana cada departamento cuenta con $50 \mathrm{~m} 2$ de espacio para que desates tu creatividad!

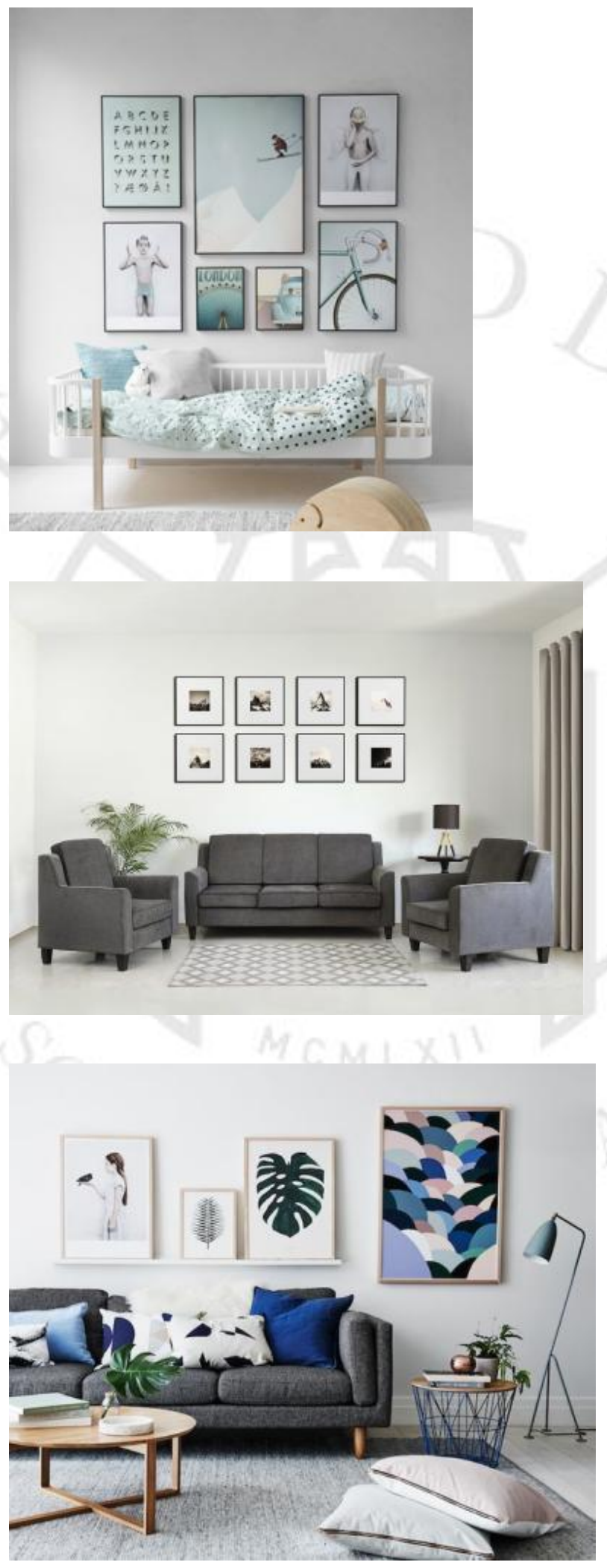


STORIES: Se realizarán stories de las personas que ya han comprado su depa: pueden ser videos de entrega de llaves, de mudanzas, fotos con el vendedor inmobiliario, etc.

\subsubsection{Twitter}

\section{Prelanzamiento}

Dentro del contenido always on, incluiremos encuestas por su gran potencial de interacción en Twitter. También compartiremos notas del blog y datos puntuales acerca de los departamentos.

\section{EJEMPLO TWEET 1: Encuesta}

¿Qué te causa más felicidad al llegar a casa? \#FelicidadEs
a. bañarte
b. cenar
c. sacarte los zapatos

\section{EJEMPLO TWEET 2:}

¿\#SabíasQue las instalaciones de la Villa Panamericana han sido implementadas con infraestructura que les permite a personas con discapacidad disfrutar libremente de cada uno de los espacios?

\section{EJEMPLO TWEET 3:}

¿\#SabíasQue cada edificio de la Villa Panamericana cuenta con cuatro ascensores, con capacidad para 18 personas y acceso a sillas de ruedas?

\section{EJEMPLO TWEET 4:}

¿\#SabíasQue señalética con sistema Braille ha sido ubicada en todos los pisos de las 7 torres de la Villa Panamericana?

\section{Lanzamiento}


Nos enfocaremos en hacer contenido interactivo. Para esta red, aprovecharemos a los ganadores peruanos de los últimos Juegos Panamericanos. La idea sería crear un hilo de interacción entre los perfiles de los embajadores de marca dentro de nuestros posts para obtener mayor relevancia y alcance. Este contenido es solo apto para un hilo y 280 caracteres. Esta táctica puede llegar a repercutir en otros medios por su naturaleza viral y la inmediatez en la que se desarrolla. Puede llegar a crecer en cuestión de minutos $u$ horas.

\section{EJEMPLO DE TWEET 1:}

Ya estamos listos para empezar la entrega de los departamentos de la Villa Panamericana, ¿están listos para la mudanza? \#VillaPanamericana \#Panamericanos

> Christian Pacheco: ¡Claro! Estoy alistando las maletas para la \#mudanza. m

> Inés Melchor: Christian, no te olvides de las zapatillas para salir mañana. Será perfecto madrugar y recorrer la pista \#Trainning

> Marcela Castillo: ¡Nos vemos Inés! Yo me acabo de mudar y mañana mismo empiezo nuevamente mis entrenamientos. Espero unirme a ti pronto para entrenar ::). \#Motivated

> Kimberly García: La Villa es perfecta para comenzar a prepararse para los próximos Panamericanos desde ya 眾. ¡Nos vemos en la pista! [b \#Entrenamiento \#Focus \#Panamericanos2020

> Alexandra Grande: Genial, ya quiero estar ahí. Durante mi estadía comprobé la calidad de sus instalaciones. Realmente vale la pena 罠. \#Calidad 
> Rosbil Guillén: $Y$ no solo eso, también cuentan con señalizaciones braille y rampas de acceso. ¡Está al alcance de todos! 장

> John Trebejo: Volver a la Villa se sentirá como volver a casa (-). \#HomeSweetHome

$>$ Gladys Tejeda: Nos vemos pronto, familia Panamericana

Diego Elías: ¡Nos vemos en la Villa! 엉

Adicionalmente a esto, complementaremos con información puntual y útil acerca de la Villa Panamericana para continuar con la función principalmente informativa.

\section{EJEMPLO TWEET 2:}

¿\#SabíasQue la Villa Panamericana cuenta con la certificación Mi Vivienda Verde? Esto quiere decir de que es ecosostenible. \#FelicidadEs vivir en un lugar ecológico y súper ahorrativo \#VillaPanamericana

\section{EJEMPLO TWEET 3:}

¿\#SabíasQue la Villa Panamericana cuenta con una pista de jogging de un kilómetro de largo que bordea las torres? ¡Suficiente espacio para ejercitar!

\subsubsection{Contenido compartido}

Adicionalmente al contenido original, también aprovecharemos contenido de las páginas de Lima 2019. 


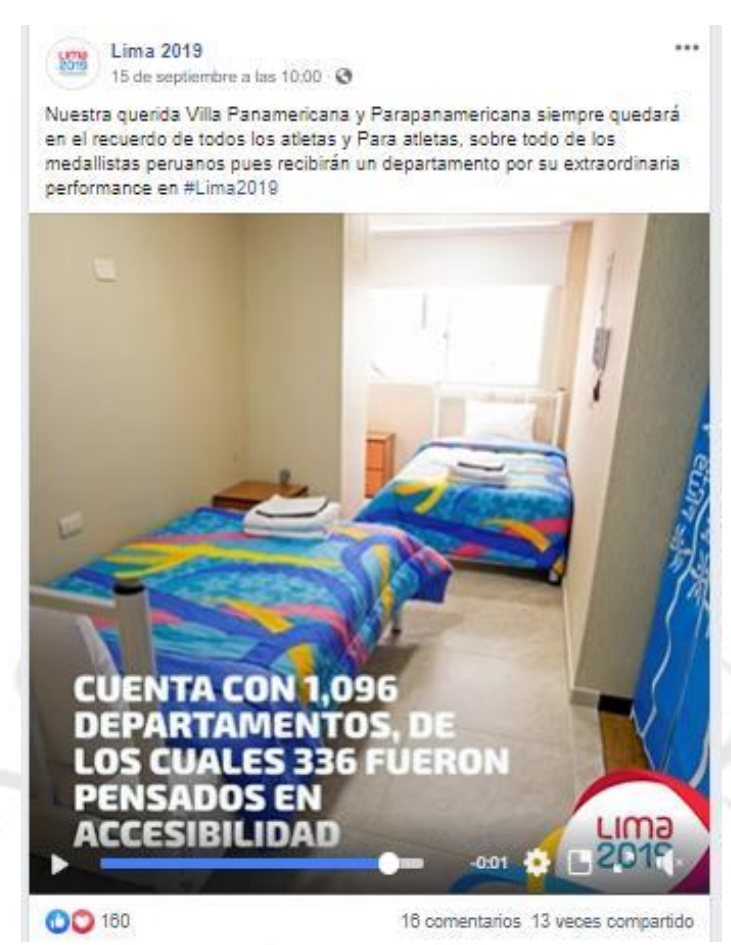

https://www.facebook.com/lima2019juegos/videos/208940014803356

\subsubsection{Marketing digital}

\section{Página web}

En la página principal, mostraremos como información dentro del home los eventos que realizaremos para captar la atención de nuestros prospectos de clientes. Adicionalmente, tendremos un menú desplegable que contendrá las siguientes secciones:

1. Financiamiento, bonos y precios.

2. Formulario de contacto para visitas con ubicación indicada en un mapa de Google Maps.

3. Galería de fotos del complejo.

\section{Leads}

Los leads se conseguirán posicionando estratégicamente los links de los formularios dentro de los conocidos Dark Post con el objetivo de conseguir inscritos y hacer una base de datos de personas interesadas a contactar. 


\section{SEO}

Nuestra meta es posicionarnos en Google, transmitir los beneficios, darles datos de importancia clave a los que estén buscando vivienda y que, luego de leer alguna nota de nuestro blog, lleguen a la página web. Esto se logra con contenido de calidad en sí mismo que sea interesante para nuestro público objetivo. También utilizaremos palabras clave para posicionarnos de manera orgánica.

\section{SEM}

Emplearemos Google Ads para implementar tres tipos de campañas de anuncio: búsqueda, display y video. En el caso de búsqueda, aquí es donde se hace uso del planificador de palabras clave propio de la herramienta. De esta manera, sabemos qué palabras son las que más nos conviene incluir en nuestro anuncio.

En el caso de la red de Display de Google, esta llega al 90\% de los usuarios de Internet del mundo a través de millones de sitios web, páginas de noticias, blogs y sitios de Google, como YouTube y Gmail. Esto se logra con banners estratégicamente ubicados en los sitios autorizados para llevar nuestra comunicación. Los banners serán adaptaciones de las piezas madre.

\section{6 Estrategia BTL}

\subsubsection{Marketing Directo}

Como medida estratégica para generará una concepción personal con nuestros potenciales consumidores, hemos ideado enviar un tapete y llavero a los primeros 100 en llenar los formularios de leads que colocaremos en redes sociales y web. Además. quienes se inscriban para el "Festival Inmobiliario Panamericano" recibirán el pase al evento como una invitación especial diseñado como un título de propiedad. Toda la información necesaria para esta ejecución proviene de los leads. 

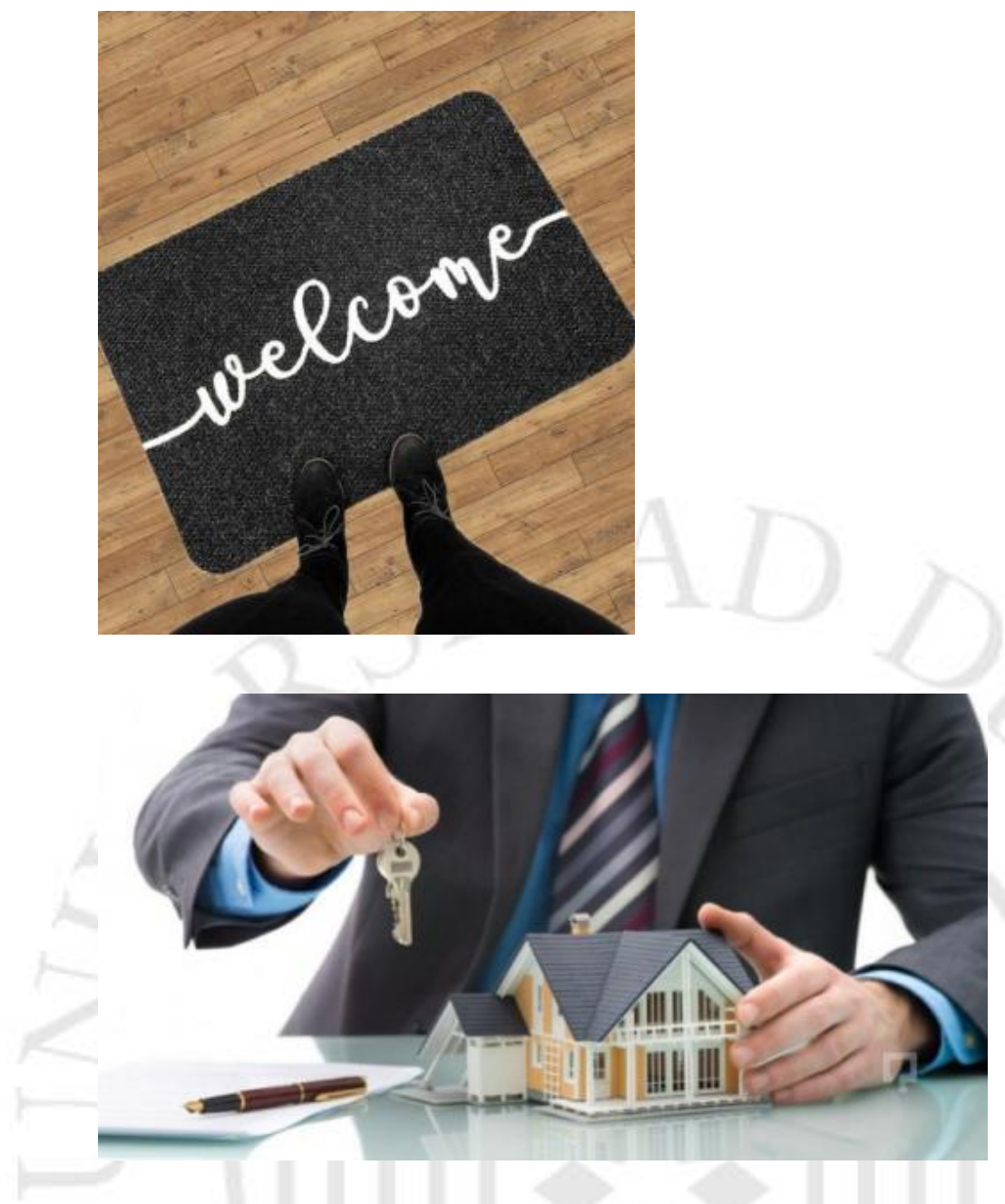

\subsubsection{Festival Inmobiliario Panamericano}

Como una manera efectiva de atraer a nuestros targets al punto de venta, que es justamente la Villa Panamericana, y de crear una experiencia positiva en dicho lugar, nace esta feria inmobiliaria. El "Festival" como lo vamos a denominar, tiene una duración de dos días (8 y 9 de febrero) lapso en el que solo nuestros leads inscritos podrán participar junto con sus familias. El plan es llevarlos a un departamento piloto, mostrarles la información de financiamiento y responder sus preguntas, para después darle acceso a la feria gastronómica y los conciertos musicales que se llevarán a cabo en el recinto deportivo del condominio (un lugar estratégico al que no se puede llegar si primero no haz pasado por las torres).

La zona gastronómica tendrá opciones fusión de comida peruana de costa, sierra y selva. Los precios de los platos se mantendrán bajos 
gracias a que pensamos en no cobrarles el espacio a los restaurantes que participen, a cambio nosotros los elegimos. Finalmente, todos los utensilios para el consumo de los alimentos cumplirán con ser eco sostenibles y biodegradables

En cuanto a la parte del concierto está planeada la participación de Mauricio Mesones, Wendy Sulca. Ellos cerrarán la velada.

Esperamos un mínimo de asistencia de 2,000 familias, es decir, 1,000 por día.

\subsection{Estrategia de medios}

Se utilizarán los espacios publicitarios distintos. Nuestra meta es llegar a la mayor cantidad de personas posible.

Para ver el desglose de medios y el Gantt:

https://docs.google.com/spreadsheets/d/1Ly92t4skV7OI7OG-

Wtr hcPI16SITQkvGyupmg3BguQ/edit?usp=sharing 


\section{CONCLUSIONES}

- La Villa Panamericana se presenta como la mejor opción para las familias limeñas compuestas de 2 o más integrantes del nivel socioeconómico $\mathrm{C}$ y $\mathrm{D}$. Dado que no existe un condómino con las facilidades financieras y con tan buena estructura, destacará en el mercado.

- La campaña de comunicación busca asociarse con el deseo ya existente de las familias por la casa propia. Es por eso que la campaña busca trabajar desde dos frentes: el emocional y el racional.

- Todos los esfuerzos comunicacionales buscan por un lado, preservar el legado de la Villa Panamericana y por otro, convencer a las familias de los NSE C y D, de que estamos frente a la mejor oportunidad de inversión y que esto los acerca a "una vida feliz". 


\section{RECOMENDACIONES}

- Balancear el contenido racional con el emocional es el camino a seguir. Sin duda la compra de un inmueble no es una decisión que se tome a la ligera. El precio final versus lo que está dispuesto a invertir el posible comprador es lo que determinará la compra.

- Los testimonios son una fuente fiable para la mayoría de las personas. Recomendamos utilizar este formato como contenido always on.

- Se recomienda aumentar la inversión para poder completar el segundo trimestre y lograr así los objetivos. 


\section{REFERENCIAS}

Álvarez, J. (2018). El shopper peruano: compra aquí y allá. ANDA, 14. Obtenido de https://www.ipsos.com/es-pe/el-shopper-peruano-compra-aqui-y-alla

Andina. (6 de setiembre de 2019). Andina.pe. Obtenido de Andina.pe: https://www.andina.pe/agencia/noticia-ahora-puedes-acceder-a-una-vivienda-5cuota-inicial-765408.aspx?fbclid=IwAR2FQ0aZeysroUgLnVjqtX0xOJwwrRwlFPIHcZoUIT3emaQCElY5hPaBCg

Andina. (19 de agosto de 2019). Andina.pe. Obtenido de Andina.pe: https://www.andina.pe/agencia/noticia-como-son-los-departamentos-la-villapanamericana-para-las-personas-discapacidad-763891.aspx

Atúncar, C. (17 de setiembre de 2019). Larepública.pe. Obtenido de Larepública.pe: https://larepublica.pe/economia/2019/09/06/bono-renta-joven-miviviendarequisitos-inscripcion-como-participar-en-fondo-mi-vivienda-peru-ventajas-ydesventajas-videos-atmp/

Bambarén, R. (28 de agosto de 2019). Gestión.pe. Obtenido de Gestión.pe: https://gestion.pe/economia/villa-panamericana-valor-de-departamentos-seriamuy-caro-para-la-zona-noticia/

Barletta, F., Pereira, M., Robert, V., \& Yoguel, G. (2013). Argentina: dinámica reciente del sector de software y servicios informáticos. Revista de la CEPAL(110), 137155. Obtenido de http://www.cepal.org/publicaciones/xml/1/50511/RVE110Yoqueletal.pdf

Choy, M., \& Chang, G. (2014). Medidas macroprudenciales aplicadas en el Perú. Lima: Banco Central de Reserva del Perú. Obtenido de http://www.bcrp.gob.pe/docs/Publicaciones/Documentos-deTrabajo/2014/documento-de-trabajo-07-2014.pdf

Confiep. (21 de agosto de 2019). confiep.org.pe. Obtenido de confiep.org.pe: https://www.confiep.org.pe/noticias/gremios-asociados/adi-peru-demandainmobiliaria-se-inclina-por-viviendas-de-51-a-80-metros-cuadrados/

Construcciónyvivienda.com. (20 de junio de 2019). Construcciónyvivienda.com. Obtenido de Construcciónyvivienda.com:

https://www.construccionyvivienda.com/component/k2/villa-panamericana-uncomplejo-habitacional-sostenible

CPI. (abril de 2019). Compañía peruana de estudios de mercado y opinión pública s.a.c. Obtenido de cpi.pe:

http://cpi.pe/images/upload/paginaweb/archivo/26/mr_poblacional_peru_20190 5.pdf

Diario Correo. (1 de Junio de 2018). Diario Correo. Obtenido de diariocorreo.pe: https://diariocorreo.pe/amp/publireportaje/cerca-del-50-de-peruanos-compradepartamentos-online-822244/

El Comercio. (28 de marzo de 2019). Elcomercio.pe. Obtenido de Elcomercio.pe: https://elcomercio.pe/tecnologia/redes-sociales/facebook-utilizan-redes-socialesperuanos-noticia- 620588

El Comercio. (6 de setiembre de 2019). ElComercio.pe. Obtenido de ElComercio.pe: https://elcomercio.pe/politica/bancada-liberal-ppk-piden-reunirse-vizcarraposible-rechazo-adelanto-elecciones-noticia-673015 
El Comercio. (4 de setiembre de 2019). ElComercio.pe. Obtenido de ElComercio.pe: https://elcomercio.pe/economia/peru/asei-25-venta-inmobiliaria-traves-fondomivivienda-noticia-nndc-

672374?fbclid=IwAR0beEDVP8WrDx4RuAcNoMJIeItJalhH2TfZxbf4KdhrkY1 LVGkWpd24CHQ

El Comercio. (19 de agosto de 2019). ElComercio.pe. Obtenido de ElComercio.pe: https://elcomercio.pe/economia/peru/precio-metro-cuadrado-lima-creceria-8cierre-2019-noticia-nndc-666961?fbclid=IwAR00weN-oTjqQb6vJCBS_RCLKm-7twdToiaxMwCWRPkJIVo2ILHKQdKhGE

El Comercio. (4 de marzo de 2019). Espacio Inmobiliario: El Comercio. Obtenido de Elcomercio.pe: https://elcomercio.pe/especial/espacioinmobiliario/noticias/minidepartamentos-tendencia-inmobiliaria-que-crece-limanoticia-1994151

El Peruano. (14 de agosto de 2019). Elperuano.pe. Obtenido de Elperuano.pe: https://www.elperuano.pe/noticia-preven-boom-inmobiliario-82440.aspx

ESAN. (23 de julio de 2018). ESAN. Obtenido de ESAN: https://www.esan.edu.pe/apuntes-empresariales/2018/07/como-influyen-lastendencias-ambientales-en-las-funcionesempresariales/?fbclid=IwAR1VIQJHUukK4NFGYZX5Utwx7a6YNYH_7UYA bcTGFoo8RD4UYvL46W6PP98

ESAN. (26 de febrero de 2019). ESAN. Obtenido de ESAN: https://www.esan.edu.pe/apuntes-empresariales/2019/02/principales-tendenciasde-consumo-que-marcaran-el2019/?fbclid=IwAR1Gr5LcbnRHhYuO65SrpbRH1_7z4VLv0NFe8xNbGxRsm K4wtsMkJMcQ_8g

Fowks, J. (17 de Abril de 2019). El País. Obtenido de ElPaís.com: https://elpais.com/internacional/2019/04/16/america/1555435510_660612.html

García Nieto, J. P. (2013). Consturye tu Web comercial: de la idea al negocio. Madrid: RA-MA.

Gestión. (08 de agosto de 2019). Gestión. Obtenido de Gestión.pe: https://gestion.pe/economia/moodys-preve-que-economia-peruana-crecera-32este-ano-y-39-en-el-2020-noticia/

Gestión. (11 de febrero de 2019). Gestión.pe. Obtenido de Gestión.pe: https://gestion.pe/tecnologia/social-media-peru-primer-pais-region-mayorporcentaje-alcance-redes-sociales-258321-noticia/

Gestión. (17 de febrero de 2019). Gestión.pe. Obtenido de Gestión.pe: https://gestion.pe/tecnologia/conozca-tendencias-tecnologia-2019-258878noticia/

Gestión. (9 de junio de 2019). Gestión.pe. Obtenido de Gestión.pe: https://gestion.pe/economia/lima-octava-ciudad-contaminada-america-latina269614-noticia/

Gestión. (23 de enero de 2019). Gestión.pe. Obtenido de Gestión.pe: https://gestion.pe/tu-dinero/inmobiliarias/otorgaran-bono-buen-pagador-s-17700-compra-viviendas-nndc-256530-noticia/

Gestión. (12 de enero de 2019). Gestión.pe. Obtenido de Gestión.pe: https://gestion.pe/tu-dinero/inmobiliarias/departamentos-villa-panamericanaseran-vendidos-forma-masiva-255546-noticia/

Gestión. (12 de enero de 2019). Gestión.pe. Obtenido de Gestión.pe: https:/gestion.pe/tu-dinero/inmobiliarias/departamentos-villa-panamericanaseran-vendidos-forma-masiva-255546-noticia/ 
Gestión. (21 de febrero de 2019). Gestión.pe. Obtenido de Gestión.pe: https://gestion.pe/tu-dinero/inmobiliarias/lima-moderna-concentra-mayorcantidad-inmuebles-adquiridos-ultimos-2-anos-259296-noticia/

Ipsos. (15 de noviembre de 2017). ipsos.pe. Obtenido de ipsos.pe: https://www.ipsos.com/es-pe/perfil-del-celunauta

Ipsos. (30 de Noviembre de 2017). ipsos.pe. Obtenido de ipsos.pe: https://www.ipsos.com/es-pe/perfil-del-smartphonero

Ipsos. (17 de agosto de 2017). Más de 60\% de la generación X quiere malls más cerca de su casa. Gestión, págs. https://www.ipsos.com/es-pe/generacion-X-mas-del60-quiere-malls-mas-cerca-de-su-casa.

Ipsos. (2018). Consumo de medios de comunicación digitales y tradicionales. Lima: Ipsos opinión y mercado S.A.

Ipsos. (8 de Febrero de 2018). ipsos.pe. Obtenido de ipsos.pe: https://www.ipsos.com/es-pe/perfiles-zonales-lima-detalle

Ipsos. (15 de Julio de 2018). ipsos.pe. Obtenido de ipsos.pe: https://www.ipsos.com/espe/perfil-del-adulto-peruano-2018

Ipsos. (2 de Julio de 2018). ipsos.pe. Obtenido de ipsos.pe: https://www.ipsos.com/espe/perfil-del-adulto-joven-peruano-2018

Ipsos. (27 de Marzo de 2018). ipsos.pe. Obtenido de ipsos.pe: https://www.ipsos.com/es-pe/smartphoneros-adultos-prefieren-oferta-dellamadas-y-los-jovenes-bonos-con-mas-internet

Ipsos. (3 de Abril de 2019). Ipsos. Obtenido de Ipsos.pe: https://www.ipsos.com/espe/perfiles-socioeconomicos-de-lima

Mejía, M. (17 de octubre de 2017). Andina. Obtenido de Andina.pe: https://andina.pe/agencia/noticia-que-edad-tienen-los-mayores-compradoresinmuebles-lima-686597.aspx

Mi casita hipotecaria. (2019). micasita.com.pe. Obtenido de micasita.com.pe: http://www.micasita.com.pe/creditos-hipotecarios/

Nexo Inmobiliario. (31 de mayo de 2018). nexoinmobiliario.pe. Obtenido de nexoinmobiliario.pe: https://nexoinmobiliario.pe/proyecto/venta-dedepartamento-15-prados-del-sol-ate-lima-lima-paz-centenario

Paz Centenario. (2 de mayo de 2019). pazcentenario.com.pe. Obtenido de pazcentenario.com.pe: https://www.pazcentenario.com.pe/departamentos-enventa/puente-piedra-ciudad-verde

Portal PQS. (13 de marzo de 2019). Portal PQS. Obtenido de Portal PQS: https://www.pqs.pe/actualidad/noticias/cinco-de-cada-10-limenos-hacendeporte?fbclid=IwAR0x9PkHMAb4Rs1rULKEkchle1ft1SYF6sBN50azfDQaL OgD3ero0JRmGqM

Revista Gan@Más. (27 de junio de 2019).revistaganamas.com.pe. Obtenido de revistaganamas.com.pe: https://revistaganamas.com.pe/urbania-mas-del-50-delimenos-prefiere-comprar-un-inmueble-en-la-zona-moderna

RPP. (22 de mayo de 2019). RPP Noticias. Obtenido de rpp.pe: https://rpp.pe/economia/economia/como-afecta-al-peru-la-guerra-comercialentre-eeuu-y-china-noticia-1198468

RPP. (6 de setiembre de 2019). rpp.pe. Obtenido de rpp.pe: https://rpp.pe/economia/economia/bono-de-alquiler-estos-son-los-requisitospara-acceder-al-subsidio-de-s-4956-renta-joven-ministerio-de-vivienda-noticia1212735? fbclid=IwAR3e7FepZBQQbUxe1 KpuOt0YhuXbD19ItsuMK1fI7V5Pa SDMT2Y1YUX1u-4 
SEMANAeconómica.com. (15 de agosto de 2019). SEMANAeconómica.com. Obtenido de SEMANAeconómica.com:

https://semanaeconomica.com/article/economia/empleo/369490-inei-empleoadecuado-en-lima-subio-2-4-entre-mayo-y-julio/

Suito, J. (21 de marzo de 2019). Mercado Negro. Obtenido de Mercado Negro: https://www.mercadonegro.pe/informes/hogares-peruanos-se-unen-a-latendencia-de-consumo-saludable/

Trigoso, M. (1 de agosto de 2018). Gestión.pe. Obtenido de Gestión.pe: https://gestion.pe/tu-dinero/inmobiliarias/37-limenos-quiere-departamentoencuentra-oferta-buscando-240268-noticia/

Wittmann, R. (2006). ¿Hubo una revolución en la lectura a finales del siglo XVIII? En G. Cavallo, \& R. Chartier, Historia de la lectura en el mundo occidental (págs. 435-472). México D.F.: Santillana.

\section{ANEXOS}

(Documentos complementarios: bocetos, guiones, entrevistas, gráficos, cuadros, etc.) 